\title{
Pilot project on the implementation of SSD2 in the frame of the electronic transmission of harmonised data collection of analytical results to EFSA: Portugal
}

\author{
National Institute of Health Doutor Ricardo Jorge, INSA, IP
}

Francisco Ravasco, Sidney Tomé, Patrícia Inácio, Luísa Oliveira

\begin{abstract}
The present report describes the work done in Portugal under the "Pilot project on the implementation of SSD2 in the frame of the electronic transmission of harmonised data collection of analytical results to EFSA" and corresponds to deliverable D6 "Report on SSD2 pilot results". This document describes all the procedure to the encoding and mapping for the residues of veterinary medicinal products (VMPR) data from the Portuguese official control plans, how that correspondence is made for the Standard Sample Description ver.2 (SSD2), the transformations required to support the controlled terminology supplied by EFSA, the transformation made on the national database PT.ON.DATA to support this new domain, the SSD2 languages and the implementation of the Web Services regarding the data transmission and Catalogues Retrieval. This document describes also the challenges encountered during the implementation of the standard model, and makes a general analysis on its limitations and potential developments. OC/EFSA/DATA/2015/02
\end{abstract}

(C) European Food Safety Authority, 2017

Key words: SSD2, controlled terminology, residues of veterinary medicinal products.

Question number: EFSA-Q-2015-00647

Correspondence: data.collection@efsa.europa.eu 
Disclaimer: The present document has been produced and adopted by the bodies identified above as author(s). This task has been carried out exclusively by the author(s) in the context of a contract between the European Food Safety Authority and the author(s), awarded following a tender procedure. The present document is published complying with the transparency principle to which the Authority is subject. It may not be considered as an output adopted by the Authority. The European Food Safety Authority reserves its rights, view and position as regards the issues addressed and the conclusions reached in the present document, without prejudice to the rights of the authors.

Suggested citation: National Institute of Health Doutor Ricardo Jorge, INSA, IP, Ravasco F., Tomé S., Inácio P., Oliveira L., 2017. Pilot project on the implementation of SSD2 in the frame of the electronic transmission of harmonised data collection of analytical results to EFSA: Portugal. EFSA supporting publication 2017:EN-1237. 59 pp. doi:10.2903/sp.efsa.2017.EN-1237

(C) European Food Safety Authority, 2017

Reproduction is authorised provided the source is acknowledged. 


\section{Summary}

The execution of the "Pilot project on the implementation of SSD2 in the frame of the electronic transmission of harmonised data collection of analytical results to EFSA" in Portugal (CONTRACT NUMBER - OC/EFSA/DATA/2015/02 - CT09) started in July 2014 with the overall objective of testing the suitability and effectiveness of Standard Sample Description ver. 2.0 (SSD2) for the reporting of data to EFSA in the residues of veterinary medicinal products (VMPR) data domain.

The project specific objectives are to:

- Design the data extraction process and define the automatic conversion in SSD2-XML data file, this objective includes improving the:

i. Guidelines for reporting data on residues of veterinary medicinal products;

ii. SSD2 data model;

iii. SSD2 catalogues;

iv. Specific requirements and the business rules.

- To test the data extraction process using data transmissions in 2016 to verify if the adaptation of the National data collection requirements to the SSD2 data model is working correctly.

- To test data transmission, for residues of veterinary medicinal products, covering all web service functionalities and methods (as described in GDE2).

- To test the retrieval of catalogues from the DCF, for the residues of veterinary medicinal products, through web service synchronization with a local repository on the data provider's side (as described in GDE2);

- To provide EFSA with a "Data standardisation document" including the mapping between the national controlled terminologies and the SSD2 terminologies for each source databases, and also including the mapping to the current standards;

- To upgrade the national information management system "alimentos PT.ON.DATA" developed under article 36 project CFP/EFSA/DATEX/2011/01/02 and recently adapted to comply with SSD2 for the data domains of food additives, chemical contaminants, pesticide residues and biological monitoring (OC/EFSA/DCM/2013/05- CT08) - to the specific data elements, controlled terminologies and business/validation rules and web services for the data domain of residues of veterinary medicinal products;

- To align the data collection of residues of veterinary medicinal products with the other data domains and EFSA requirements;

- To perform 2016 data transmissions for the residues of veterinary medicinal products to EFSA in SSD2;

- To provide EFSA with a "Report on Web Services Implementation: on Data Transmission and Catalogues Retrieval Implementation from Data Provider Side" taking into account a description of the implementation of transmission of data via web services and containing a description of the catalogues retrieval and synchronization process via web service to/from the DCF, highlighting possible problems encountered and recommendations for future improvements; 
- To provide EFSA with a detailed "Report on SSD2 pilot results" describing the work and tools developed, challenges encountered, experience gained in testing SSD2, and recommendations for EFSA on the effectiveness and suitability of the SSD2 in residues of veterinary medicinal products domain.

This document corresponds to D6, all the procedure for the encoding and mapping for the VMPR data from the Portuguese official control plan, how that correspondence is made for the Standard Sample Description ver.2 (SSD2), the transformations required to support the controlled terminology supplied by EFSA, the transformation made on the national database "alimentos PT.ON.DATA" to support VMPR domain, the SSD2 languages and the implementation of the Web Services regarding the data transmission and Catalogues Retrieval. This document describes also the challenges encountered during the implementation of the standard model and makes a general analysis on its limitations and potential developments. 


\section{Table of contents}

Pilot project on the implementation of SSD2 in the frame of the electronic transmission of harmonised data collection of analytical results to EFSA

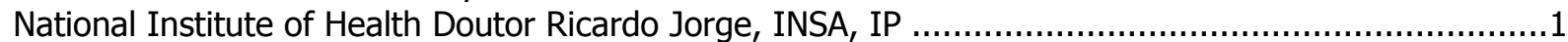

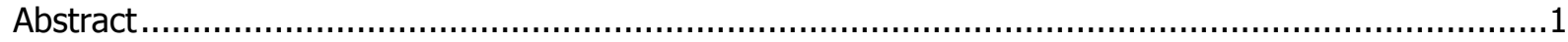

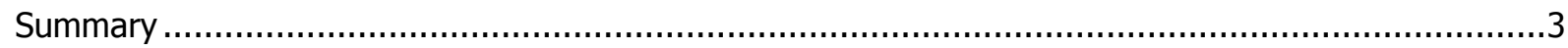

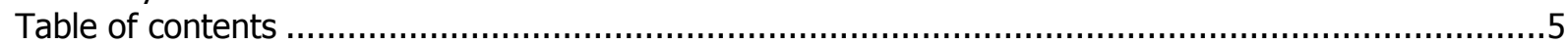

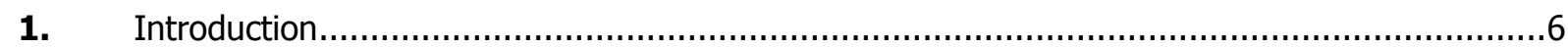

1.1. Background and Terms of Reference as provided by the requestor ................................6

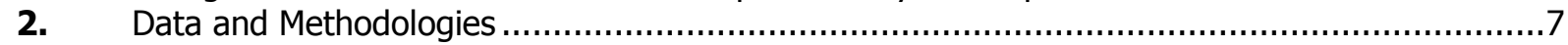

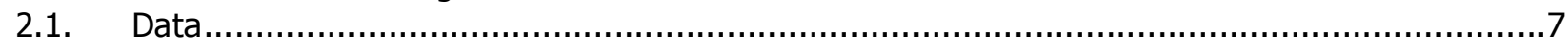

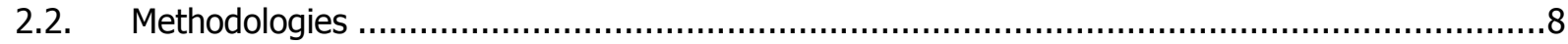

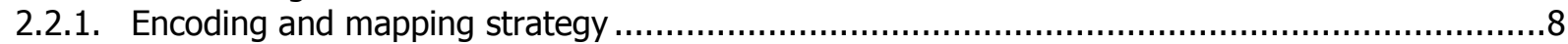

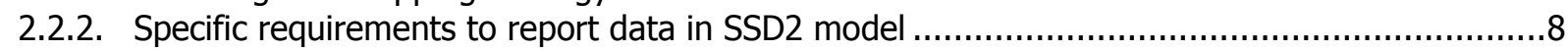

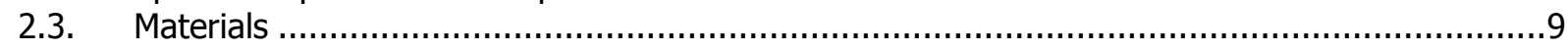

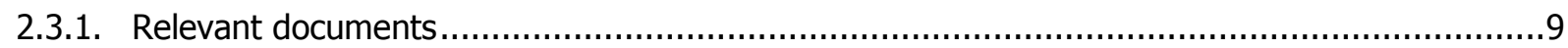

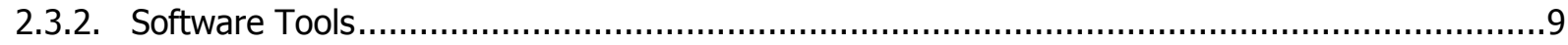

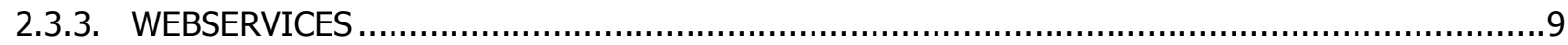

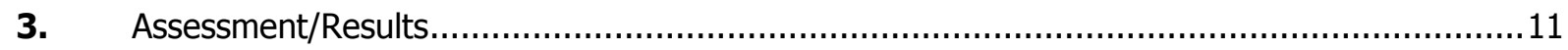

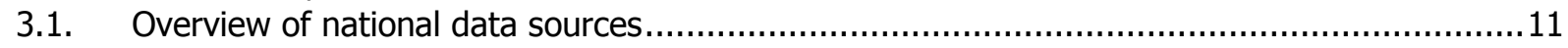

3.2. Mapping between the current systems data elements and the VMPR data elements .............11

3.3. Defining specific requirements to report data in SSD2 model by data domain .....................13

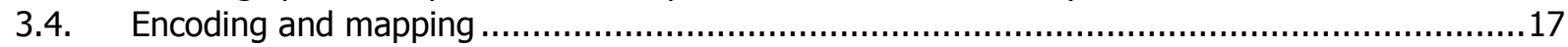

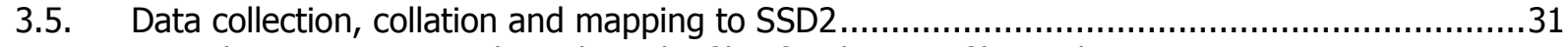

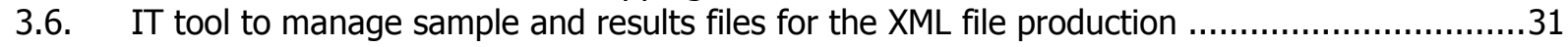

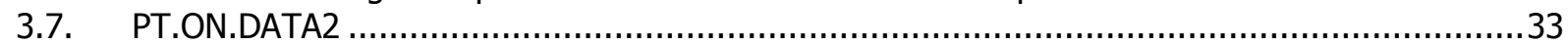

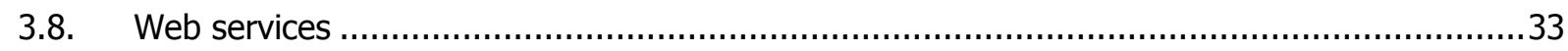

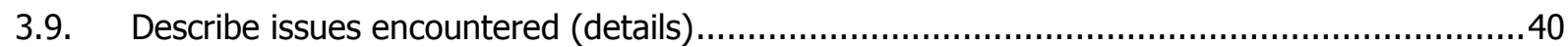

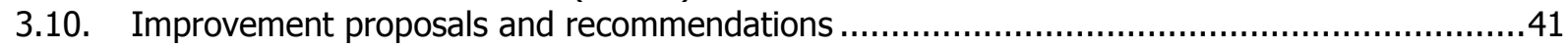

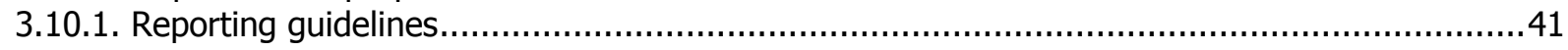

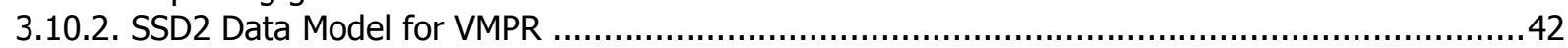

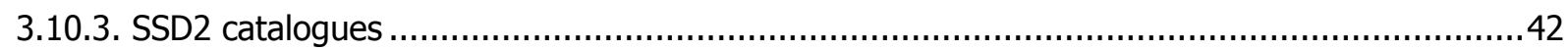

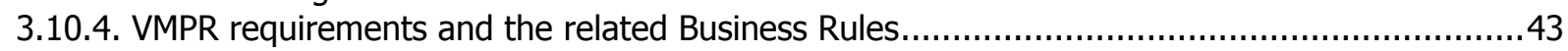

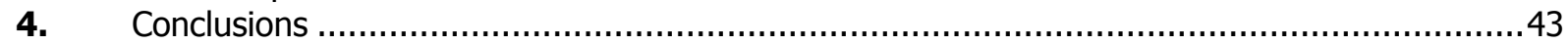

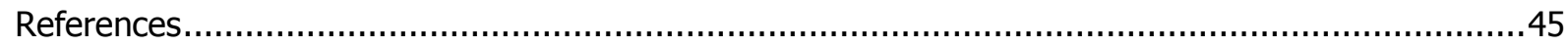

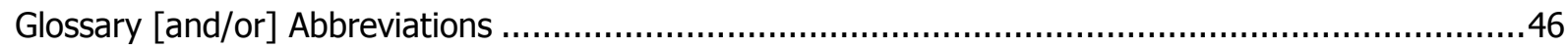

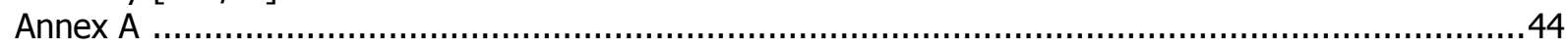




\section{Introduction}

\subsection{Background and Terms of Reference as provided by the requestor}

Article 33 of the Regulation (EC) $178 / 2002^{1}$ of the European Parliament and of the Council states that EFSA:

- "shall search for, collect, collate, analyse and summarise relevant scientific and technical data in the fields within its mission. This shall involve in particular the collection of data relating to food consumption and the exposure of individuals to risks related to the consumption of food";

- "shall work in close cooperation with all organisations operating in the field of data collection, including those from applicant countries, third countries or international bodies".

In addition, specific EU legislation on data collection exists for specific data collection domains:

- For the residues of veterinary medicinal products area, Article 8 of Regulation (EC) No $96 / 23 / \mathrm{EC}^{2}$ requires Member States to submit the results of the VMPR monitoring programme on annual basis to the Commission.

In 2010 the SSD Guidance Document ${ }^{3}$ and in 2014 the Guidance on Data Exchange (GDE) ${ }^{4}$ were published defining a standard format to transmit chemical occurrence analytical data in food and feed samples to EFSA. These guidance documents describe the data model and data interchange protocol ${ }^{5}$ for reporting the results of laboratory tests on food and feed samples in several food domains (contaminants, pesticides, etc.).

Since 2010, the use of the SSD has been fully implemented and used in the national competent authorities and laboratories in 27 Member States and two EFTA countries (Iceland and Norway) involved in the pesticide monitoring data collection. In addition to the general SSD Guidance Document mentioned above, an EFSA Guidance Document on the use on the use of the SSD for each data domain report.

EFSA Advisory Forum, aware of the proliferation of data transmission standards in the different data collection domains, prepared a technical report presented at a meeting in Poland 28-29 September $2011^{6}$.This document contains the following recommendation:

\footnotetext{
${ }^{1}$ REGULATION (EC) No 178/2002 OF THE EUROPEAN PARLIAMENT AND OF THE COUNCIL, of 28 January 2002 laying down the general principles and requirements of food law, establishing the European Food Safety Authority and laying down procedures in matters of food safety $O J L 31,1.2 .2002$, p. 1-24.

2 COUNCIL DIRECTIVE 96/23/EC of 29 April 1996 on measures to monitor certain substances and residues thereof in live animals and animal products and repealing Directives 85/358/EEC and 86/469/EEC and Decisions 89/187/EEC and 91/664/EEC 91/414/EEC OJ L 125, 23.5.1996, p. 10-32.

${ }^{3}$ European Food Safety Authority; Standard sample description for food and feed. EFSA Journal. 2010; 8(1): 1457 [54 pp.]. doi:10.2903/j.efsa.2010.1457. Available online: www.efsa.europa.eu

4 European Food Safety Authority; Guidance on Data Exchange 2.0 EFSA Journal 2014;12(12):3945 doi: 10.2903/j.efsa.2014.3945. Available online: www.efsa.europa.eu/en/efsajournal/pub/3945.htm

${ }^{5}$ Electronic data interchange: is the structured transmission of data between organizations by electronic means. It is used to transfer electronic documents or business data from one computer system to another computer system.

${ }^{6}$ Technical Report of the EFSA Advisory Forum Discussion Group on Data Collection
} 
"A Task Force should be established to coordinate improvements in data and process integration and act as a horizontal review group on the outcomes from the various domain groups, taking into consideration all existing standards. The composition of this Task Force should ensure that all domains are represented. This group in particular should have a role in the development of a common catalogue for all data collection purposes in order to enable maximum use of data collected across the different areas of expertise.

Therefore, a Working Group on SSD Extension (WG-SSD2) was established in 2012 to extend the SSD to include the domains that were not yet covered, and to provide a framework for the collection of harmonised analytical measurement data on chemical and microbiological contaminants in different matrices (e.g. food, feed, animals, water, environmental samples, food contact materials).

The amended standard proposed by the working group WG-SSD2 is called Standard Sample Description version 2 (SSD2).

On December 2013, EFSA received a mandate from the EC to develop a sample-based data collection system which would allow direct data submission by Member States (MSs) of data obtained in accordance with the framework of Council Directive 96/23/EC, and to prepare a compilation of these data annually. In March 2015 EFSA publish the specific guidance where conclude that the data model for the VMPR data collection is completely compatible with the SSD2 data model and that SSD2 catalogues (as published and maintained for all EFSA data domains) contain all the controlled terminology values needed for the reporting of VMP residues.

The Contract of the "Pilot project on the implementation of SSD2 in the frame of the electronic transmission of harmonised data collection of analytical results to EFSA" (CONTRACT NUMBER OC/EFSA/DATA/2015/02-CT09) was awarded by EFSA to Instituto Nacional de Saúde Doutor Ricardo Jorge with the purpose of testing if the SSD2 is a suitable and effective tool for the reporting data to EFSA in VMPR data collection domain, extending the functionality of the current SSD (i.e. SSD1).

The deliveries of the project have been agreed as follows:

\begin{tabular}{|l|l|}
\hline D1 & Data standardisation document \\
\hline D2 & Data transmitted to the EFSA DCF according to the SSD2-XML file format \\
\hline D3 & $\begin{array}{l}\text { Report on Web Services Implementation regarding data transmission from Data } \\
\text { Provider Side }\end{array}$ \\
\hline D4 & $\begin{array}{l}\text { Report on Web Services Implementation regarding Catalogues Retrieval from Data } \\
\text { Provider Side }\end{array}$ \\
\hline D5 & Draft version of the "Report on SSD2 pilot results". \\
\hline D6 & $\begin{array}{l}\text { Final version of "Report on SSD2 pilot results", addressing EFSA's comments on the } \\
\text { draft report (D5). }\end{array}$ \\
\hline
\end{tabular}

\section{Data and Methodologies}

\subsection{Data}

Portugal currently has one National Competent Authorities operating the VMPR national official control plan (DGAV) and one official laboratory (INIAV) that carrying out the analysis of the national official control of food, feed and animal samples. DGAV has their own database (SIPACE) where records all the data of the samples collected and correspondent laboratory results this system (structure) uses 
some fields with controlled vocabulary and others with free text. INIAV have a LIMS (NAUTILUS) where all analytical results are gathered, not all the fields have controlled vocabulary and some of important information cannot be extracted from the LIMS because does not exist isolated on the system. Data from each source (sample and analytical data information) is exported to Excel file. After a previous treatment the data file with all detailed data was loaded at the new national database "alimentos PT.ON.DATA 2.0" witch converts the data in the SSD2 specific data elements and controlled terminologies according to all the specific business rules.

The new developed database will be adopted by DGAV as a management tool to control all the control plans coordinated by this Authority.

\subsection{Methodologies}

\subsubsection{Encoding and mapping strategy}

Documents, including Excel file data models, were searched at EFSA's website and also provided by the national competent authorities (CA's) and by the national official laboratory; the documents provided by the national CA's were the controlled terminologies and the data elements in use in their databases.

The national database "alimentos PT.ON.DATA" was built following the SSD1 architecture for Chemical Contaminants, with the addition of secondary tables that were created to aid data retrieval for further processing. The system was prepared to follow the mapping between the SSD1 and SSD2 standards provided by EFSA. It was recently updated to receive data from the other domains included on the Portuguese control plans.

In order to accomplish the task of performing the correlation between the data stored in the different systems belonging to the CA's (SIPACE and NAUTILUS), and the multiple data elements currently specified with the new proposed standard SSD2, an initial process of analysis was planned and its completion led to the mapping solution which will be described later on, in the Results section.

The data elements, as well as the controlled vocabularies in use by the competent authorities, were collected and mapped to EFSA's SSD2 elements and catalogues.

As for the process of mapping the national competent authorities controlled terminologies related to food matrixes, we used the last version of the FoodEx2 catalogue made available through the EFSAs' online document management system ${ }^{7}$.

\subsubsection{Specific requirements to report data in SSD2 model}

The specific requirements to report data in SSD2 for VMPR domain with the constraints for the data transmission are present in the Technical Report with the guidelines to be used in conjunction with the Standard Sample Description version 2.0 (SSD2) and the Guidance on Data Exchange version 2.0 (GDE2). They provide specific guidance on the VMPR data model, data elements, the controlled terminology values and VMPR-specific business rules which are applicable to this domain.

\footnotetext{
${ }^{7}$ https://dms.efsa.europa.eu/otcs/cs.exe?func=\|l\&objId=11023773\&objAction=browse\&sort=name 


\subsection{Materials}

\subsubsection{Relevant documents}

All the documents used to produce deliverable D6 are listed under References.

\subsubsection{Software Tools}

Microsoft Office Excel 2007

Foodex2 browsing tool

As for the development that took place while the received data was being prepared, some software development tools were used by the IT members of the team. The tools that are going to be described allowed the creation of multiples single purpose tools which helped the team with the current data report to EFSA, following the new version of the standard (SSD2) and the implied data transformation.

Both types of software tools, the ones used for development and the ones that were the outcome of that development, were chosen with the purpose of creating useful applications in the smallest amount of time possible in order to meet the data reporting deadline, since that would be a very hard task to achieve if the technicians were to perform the data transformation under the SSD2 rules all manually.

For the software development, the IDE used was Microsoft's Visual Studio 2013 to create a Windows Form application under the .NET 4.5 Framework.

As for the Database management tool, the software used was Microsoft's SQL Server 2014 Management Studio, since it facilitated the process of importing the files with the information to be reported, once these files were prepared by the technicians. The Excel files were imported using the SQL Server Import and Export Wizard, all the remaining operations applied to the data were performed using SQL related commands and tasks.

\subsubsection{WEBSERVICES}

One of the dominant problems we encountered over the years when submitting data to EFSA was the number of human errors that would occur with the data treatment, and the process of data submission itself. Using the older INSA platform as an example, although having all the SSD v.1 business and other rules implemented internally only when submitting the data through the DCF was when most errors were identified. Encountering errors on our data reports via the DCF, most of the time meant that only on the next day those errors could be solved, delaying the actual final submission that had to occur before the deadline. Finding errors through the DCF also meant that the problems with the data had to be fixed on the source files, normally Excel files, that had be imported again on our system, mapped, treated, and validated internally only to have it imported again on the DCF platform for final validation. In many occasions this whole process of correcting the data would occur multiple times, consuming large amount of time.

In the older PT.ON.DATA platform, the new catalogues were acquired manually through EFSA's website or other medium, and had to be analysed, again manually, in order to identify which terms were out-dated and which were new to the catalogue so they could be inserted into the system's database. Since this was a task performed by a specialist assigned to the task, and since the task 
consists on a more manual process (specialist side) than an automated process (software side), it was a very time consuming thing to be done and for some occasions it created some disparity between the catalogues used to transform and validate the data on our side versus the catalogues expected by the DCF on EFSA's side.

We decided that for the new platform that had to be developed for the new version of the SSD v.2, we had to try to cut the amount of work performed by the specialists that were managing the data with the main purpose of improving the data quality and information retrieval efficiency. After seeing in the GDE2 that the Web Services communication between EFSA's platforms were a possibility from now on, we concluded that the catalogues management and data submission aspects on our side could be greatly improved. 


\section{Assessment/Results}

\subsection{Overview of national data sources}

The data sources of this project are discriminated in table 1 below.

Table 1: Data sources overview

\begin{tabular}{|c|c|c|c|}
\hline Entity & Matrices & Domain & Data Source \\
\hline $\begin{array}{c}\text { DGAV (General } \\
\text { Directorate of Food } \\
\text { and Veterinary } \\
\text { Affairs) }\end{array}$ & $\begin{array}{c}\text { Food, Feed, } \\
\text { Animal samples }\end{array}$ & $\begin{array}{c}\text { Residues of } \\
\text { veterinary medicinal } \\
\text { products }\end{array}$ & $\begin{array}{c}\text { SIPACE } \\
\text { database: Excel } \\
\text { file }\end{array}$ \\
\hline $\begin{array}{c}\text { INIAV (National } \\
\text { Agrarian and } \\
\begin{array}{c}\text { Veterinary Research } \\
\text { Institute) }\end{array}\end{array}$ & $\begin{array}{c}\text { Food, Feed, } \\
\text { Animal samples }\end{array}$ & $\begin{array}{c}\text { Residues of } \\
\text { verinary medicinal } \\
\text { products }\end{array}$ & $\begin{array}{c}\text { LIMS } \\
\text { (NAUTILUS): } \\
\text { Excel file }\end{array}$ \\
\hline
\end{tabular}

Regarding the different entities:

- DGAV:

The database (SIPACE) present in this authority, feature data from national official control plans.

SIPACE database contains sampling collected and aggregated analytical data, which is converted in a excel file. All controlled terminologies such as parameters, analytical method, etc., were converted to SSD2 catalogues provided by EFSA.

- INIAV:

This entity is an official laboratory for the analyses of the samples collected in the national official control plans.

Laboratory system NAUTILUS contains analytical data, and this information can be exported to an excel file. All controlled terminologies such as parameters, analytical method, etc., were converted to SSD2 catalogues provided by EFSA. Some information needed is sent in an additional Excel file since is not possible to export from the LIMS system (e.g. LOD, LOQ, CCa, CC $\beta$ ). Some information was aggregated and it was necessary to disaggregated them to make the transmission.

\subsection{Mapping between the current systems data elements and the VMPR data elements}

Regarding the "alimentos PT.ON.DATA" platform and its database, after the evaluation of multiple elements and different key points related to the database, we concluded that, as result of having two main tables with an almost identical format to the SSD1 shown by figure 1, which were used to store all information originated from the competent authorities reports, the process of mapping the SSD1 data gathered via the platform to the SSD2 standard could be done by following the correspondence between the two standards already established by EFSA. 

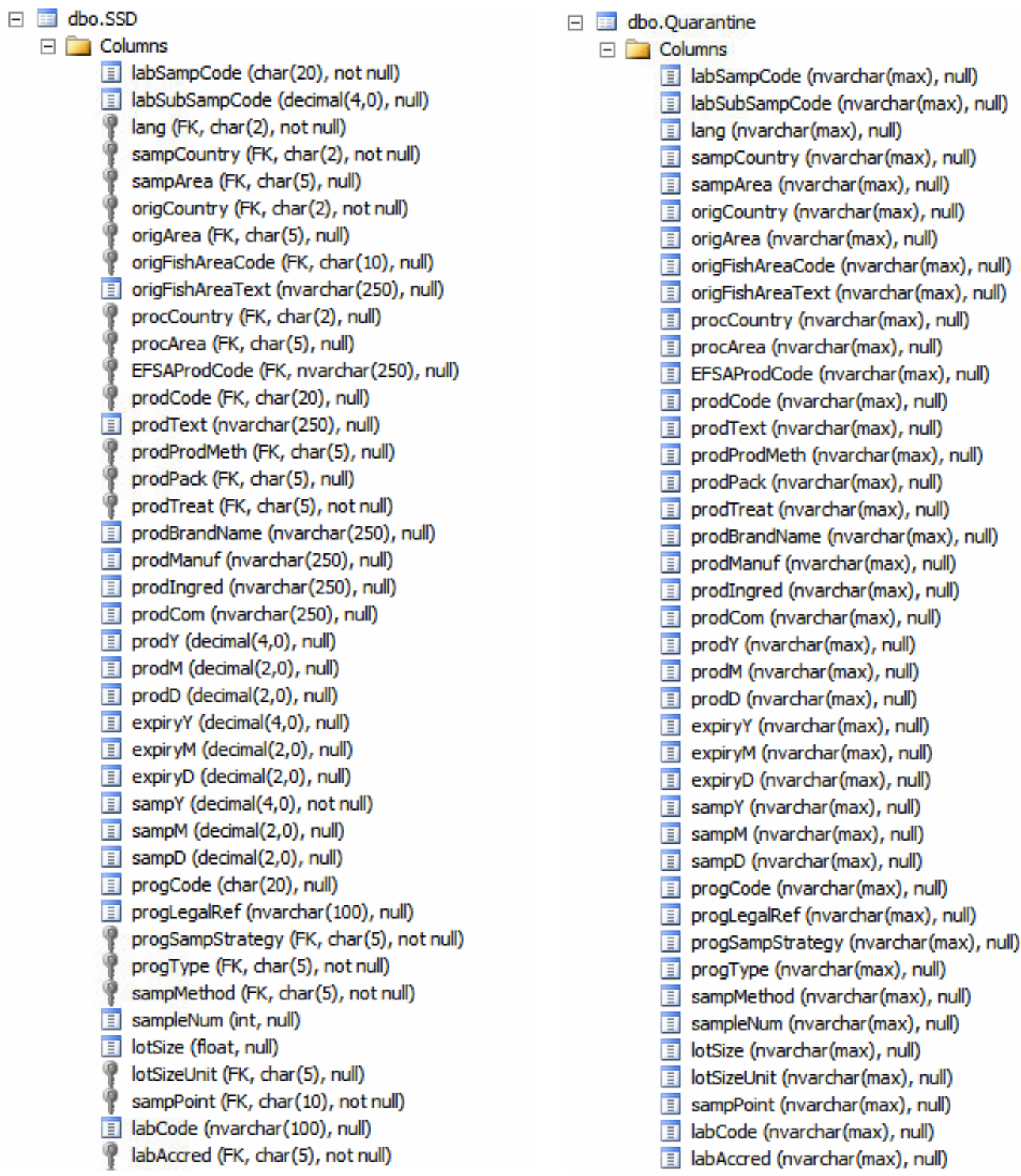

Figure 1: $\quad$ Current SSD v.1 primary tables structure in the Database

Using the mapping table present in the document that describes the SSD2 standard, it was possible and clear to implement an intermediary tool that takes the existing "alimentos PT.ON.DATA" database, primarily the dbo.SSD and dbo.Quarantine tables, and populate a new database with the same data transformed into the SSD2 standard. To better describe this process, the "Mapping from SSD1 to SSD2 in the contaminants and pesticide area" table from the Standard Sample Description ver. 2.0 document published by EFSA were thoroughly examined and every mapping between the two versions of the SSD was coded into a new custom tool that searched for the SSD1 field and its value inside the SSD1 database (taking into account whether an controlled terminology was used or not), and populate the corresponding SSD2 field inside the SSD2 database with its correct value. 


\subsection{Defining specific requirements to report data in SSD2 model by data domain}

Summary tables describing the specific requirements to report data in SSD2 model were produced using the approach described in point 2.1.4., Table 2 - Specific Requirements to report data in SSD2 in VMPR data domain. 
Table 2: Specific Requirements to report data in SSD2 in residues of veterinary medicinal products (VMPR) data domain

\begin{tabular}{|c|c|c|c|c|c|c|c|c|}
\hline $\begin{array}{l}\text { Element } \\
\text { code }\end{array}$ & $\begin{array}{l}\text { Section } \\
\text { code }\end{array}$ & Section & Element name & Element label & Type & $S / R / C^{(a)}$ & $\begin{array}{c}\text { Controlled } \\
\text { terminology }\end{array}$ & $\begin{array}{c}M / O / R / D \\
M / D^{(b)}\end{array}$ \\
\hline A.01 & A & Local organisation & localOrgId & Local organisation identification code & xs:string (100) & $\mathrm{S}$ & & $\mathrm{O}$ \\
\hline A.02 & A & Local organisation & localOrgCountry & Local organisation country & xs:string (2) & $\mathrm{S}$ & COUNTRY & 0 \\
\hline A.03 & A & Local organisation & localOrgInfo & Local organisation additional information & CompoundType & $\mathrm{C}$ & & 0 \\
\hline B.01 & B & $\begin{array}{l}\text { Sampling } \\
\text { programme }\end{array}$ & progId & Sampling programme identification code & xs:string (100) & $\mathrm{S}$ & & 0 \\
\hline B.02 & B & $\begin{array}{l}\text { Sampling } \\
\text { programme }\end{array}$ & progLegalRef & Programme legal reference & xs:string (5) & $\mathrm{R}$ & LEGREF & $\mathrm{R}$ \\
\hline B.03 & B & $\begin{array}{l}\text { Sampling } \\
\text { programme }\end{array}$ & sampStrategy & Sampling strategy & xs:string (5) & $\mathrm{S}$ & SAMPSTR & M \\
\hline B.04 & B & $\begin{array}{l}\text { Sampling } \\
\text { programme }\end{array}$ & progType & Programme type & xs:string (5) & $\mathrm{S}$ & PRGTYP & M \\
\hline B.05 & B & $\begin{array}{l}\text { Sampling } \\
\text { programme }\end{array}$ & sampMethod & Sampling method & xs:string (5) & $\mathrm{s}$ & SAMPMD & 0 \\
\hline B.06 & B & $\begin{array}{l}\text { Sampling } \\
\text { programme }\end{array}$ & sampler & Sampler & xs:string (5) & S & SAMPLR & $M$ \\
\hline B.07 & B & $\begin{array}{l}\text { Sampling } \\
\text { programme }\end{array}$ & sampPoint & Sampling point & xs:string (5) & $\mathrm{S}$ & SAMPNT & M \\
\hline B.08 & B & $\begin{array}{l}\text { Sampling } \\
\text { programme }\end{array}$ & progInfo & Additional sampling program information & CompoundType & $\mathrm{C}$ & & 0 \\
\hline C.01 & $\mathrm{C}$ & Sampling event & sampEventId & Sampling event identification code & xs:string (100) & $\mathrm{s}$ & & 0 \\
\hline C.02 & $\mathrm{C}$ & Sampling event & sampUnitType & Sampling unit type & xs:string (5) & $\mathrm{S}$ & SAMPUNTYP & M \\
\hline C.03 & $\mathrm{C}$ & Sampling event & sampUnitSize & Sampling unit size & xs:double & $\mathrm{S}$ & & 0 \\
\hline C.04 & $\mathrm{C}$ & Sampling event & sampUnitSizeUnit & Sampling unit size unit & xs:string (5) & $\mathrm{S}$ & UNIT & DM \\
\hline C.05 & $\mathrm{C}$ & Sampling event & sampUnitIds & Other sampling unit identifications & CompoundType & $\mathrm{C}$ & & M \\
\hline C.06 & $\mathrm{C}$ & Sampling event & sampEventInfo & Additional sampling event information & CompoundType & $\mathrm{C}$ & & 0 \\
\hline D.01 & D & Sample taken & sampId & Sample taken identification code & xs:string (100) & $\mathrm{S}$ & & M \\
\hline D.02 & D & Sample taken & repCountry & Reporting country & $x s$ :string (2) & $\mathrm{s}$ & COUNTRY & 0 \\
\hline D.03 & D & Sample taken & sampCountry & Country of sampling & xs:string (2) & $\mathrm{S}$ & COUNTRY & M \\
\hline D.04 & D & Sample taken & sampArea & Area of sampling & xs:string (5) & $\mathrm{s}$ & NUTS & 0 \\
\hline D.06 & D & Sample taken & sampY & Year of sampling & xs:integer (4) & $\mathrm{s}$ & & M \\
\hline D.07 & D & Sample taken & sampM & Month of sampling & xs:integer (2) & $\mathrm{s}$ & & 0 \\
\hline D.08 & D & Sample taken & sampD & Day of sampling & $x$ s:integer (2) & $\mathrm{S}$ & & 0 \\
\hline D.09 & D & Sample taken & sampSize & Sample taken size & xs:double & $\mathrm{s}$ & & 0 \\
\hline D.10 & D & Sample taken & sampSizeUnit & Sample taken size unit & xs:string (5) & $\mathrm{s}$ & UNIT & DM \\
\hline D.11 & D & Sample taken & sampInfo & Additional sample taken information & CompoundType & $\mathrm{C}$ & & DM \\
\hline
\end{tabular}




\begin{tabular}{|c|c|c|c|c|c|c|c|c|}
\hline $\begin{array}{l}\text { Element } \\
\text { code }\end{array}$ & $\begin{array}{l}\text { Section } \\
\text { code }\end{array}$ & Section & Element name & Element label & Type & $S / R / C^{(a)}$ & $\begin{array}{c}\text { Controlled } \\
\text { terminology }\end{array}$ & $\begin{array}{l}M / O / R / D \\
M / D^{(b)}\end{array}$ \\
\hline E.01 & $\bar{E}$ & Matrix sampled & sampMatType & Type of matrix & xs:string (5) & $\mathrm{s}$ & MTXTYP & $\bar{M}$ \\
\hline E.02 & $\mathrm{E}$ & Matrix sampled & sampMatCode & $\begin{array}{l}\text { Coded description of the matrix of the } \\
\text { sample taken }\end{array}$ & CompoundType & C & MTX & M \\
\hline E.03 & $\mathrm{E}$ & Matrix sampled & sampMatText & $\begin{array}{l}\text { Text description of the matrix of the } \\
\text { sample taken }\end{array}$ & xs:string (250) & $\mathrm{S}$ & & R, DM \\
\hline E.04 & $\mathrm{E}$ & Matrix sampled & origCountry & Country of origin of the sample taken & xs:string (2) & $\mathrm{s}$ & COUNTRY & M \\
\hline E.05 & $\mathrm{E}$ & Matrix sampled & origArea & Area of origin of the sample taken & xs:string (5) & $\mathrm{s}$ & NUTS & 0 \\
\hline E.06 & $\mathrm{E}$ & Matrix sampled & origFishAreaCode & $\begin{array}{l}\text { Area of origin for fisheries or aquaculture } \\
\text { activities code of the sample taken }\end{array}$ & xs:string (10) & $\mathrm{S}$ & FAREA & $\mathrm{O}$ \\
\hline E.07 & $\mathrm{E}$ & Matrix sampled & origFishAreaText & $\begin{array}{l}\text { Area of origin for fisheries or aquaculture } \\
\text { activities text of the sample taken }\end{array}$ & xs:string (250) & $\mathrm{s}$ & & $\mathrm{O}$ \\
\hline E.08 & $\mathrm{E}$ & Matrix sampled & procCountry & $\begin{array}{l}\text { Country of processing of the sample } \\
\text { taken }\end{array}$ & xs:string (2) & $\mathrm{s}$ & COUNTRY & $\mathrm{O}$ \\
\hline E.09 & $\mathrm{E}$ & Matrix sampled & procArea & Area of processing of the sample taken & xs:string (5) & $\mathrm{s}$ & NUTS & $\mathrm{O}$ \\
\hline E.10 & $\mathrm{E}$ & Matrix sampled & sampMatInfo & $\begin{array}{l}\text { Additional information on the matrix } \\
\text { sampled }\end{array}$ & CompoundType & C & & $\mathrm{O}$ \\
\hline F.01 & $\mathrm{F}$ & Sample analysed & sampAnId & Sample analysed identification code & xs:string (100) & $\mathrm{s}$ & & 0 \\
\hline F.03 & $\mathrm{F}$ & Sample analysed & analysisY & Year of analysis & xs:integer (4) & $\mathrm{s}$ & & M \\
\hline F.04 & $\mathrm{F}$ & Sample analysed & analysisM & Month of analysis & xs:integer (2) & $\mathrm{S}$ & & 0 \\
\hline F.05 & $\mathrm{F}$ & Sample analysed & analysisD & Day of analysis & xs:integer (2) & $\mathrm{S}$ & & $\mathrm{O}$ \\
\hline F.06 & $\mathrm{F}$ & Sample analysed & sampAnInfo & $\begin{array}{l}\text { Additional information on the sample } \\
\text { analysed }\end{array}$ & CompoundType & C & & $\mathrm{O}$ \\
\hline G.01 & G & Matrix analysed & anMatCode & Coded description of the analysed matrix & CompoundType & $\mathrm{C}$ & MTX & DM \\
\hline G.02 & G & Matrix analysed & anMatText & Text description of the matrix analysed & xs:string (250) & $\mathrm{s}$ & & $\mathrm{DR}$ \\
\hline G.03 & G & Matrix analysed & anMatInfo & $\begin{array}{l}\text { Additional information on the analysed } \\
\text { matrix }\end{array}$ & CompoundType & C & & $\mathrm{O}$ \\
\hline H.01 & $\mathrm{H}$ & $\begin{array}{l}\text { Sample analysed } \\
\text { portion }\end{array}$ & anPortSeq & Sample analysed portion sequence & xs:string (100) & $\mathrm{s}$ & & $\mathrm{O}$ \\
\hline H.02 & $\mathrm{H}$ & $\begin{array}{l}\text { Sample analysed } \\
\text { portion }\end{array}$ & anPortSize & Sample analysed portion size & xs:double & $\mathrm{s}$ & & $\mathrm{O}$ \\
\hline H.03 & $\mathrm{H}$ & $\begin{array}{l}\text { Sample analysed } \\
\text { portion }\end{array}$ & anPortSizeUnit & Sample analysed portion size unit & xs:string (5) & $\mathrm{S}$ & UNIT & DM \\
\hline H.04 & $\mathrm{H}$ & $\begin{array}{l}\text { Sample analysed } \\
\text { portion }\end{array}$ & anPortInfo & $\begin{array}{l}\text { Additional information on the sample } \\
\text { analysed portion }\end{array}$ & CompoundType & C & & $\mathrm{O}$ \\
\hline J.01 & J & Laboratory & labId & Laboratory identification code & xs:string (50) & $\mathrm{s}$ & & $\mathrm{R}$ \\
\hline 3.02 & J & Laboratory & labAccred & Laboratory accreditation & xs:string (1) & $\mathrm{s}$ & LABACC & M \\
\hline 3.03 & J & Laboratory & labCountry & Laboratory country & xs:string (2) & $\mathrm{s}$ & COUNTRY & $\mathrm{O}$ \\
\hline 3.04 & $\mathrm{~J}$ & Laboratory & labInfo & Additional information on the laboratory & CompoundType & C & & $\mathrm{O}$ \\
\hline
\end{tabular}




\begin{tabular}{|c|c|c|c|c|c|c|c|c|}
\hline $\begin{array}{l}\text { Element } \\
\text { code }\end{array}$ & $\begin{array}{l}\text { Section } \\
\text { code }\end{array}$ & Section & Element name & Element label & Type & $S / R / C^{(a)}$ & $\begin{array}{c}\text { Controlled } \\
\text { terminology }\end{array}$ & $\begin{array}{c}\mathrm{M} / \mathrm{O} / \mathrm{R} / \mathrm{D} \\
\mathrm{M} / \mathrm{DR}^{(\mathrm{b})}\end{array}$ \\
\hline K.01 & $\bar{K}$ & Parameter & paramType & Type of parameter & xs:string (5) & $\bar{S}$ & PARAMTYP & $\mathrm{M}$ \\
\hline K.02 & $\mathrm{K}$ & Parameter & paramCode & Coded description of the parameter & CompoundType & $\mathrm{C}$ & PARAM & M \\
\hline K.03 & K & Parameter & paramText & Parameter text & xs:string (250) & $\mathrm{S}$ & & DM \\
\hline L.01 & $\mathrm{L}$ & Analytical method & anMethRefId & Analytical method identification & xs:string (50) & $\mathrm{s}$ & & $\mathrm{O}$ \\
\hline L.02 & $\mathrm{L}$ & Analytical method & anMethRefCode & Analytical method reference code & xs:string (5) & $\mathrm{S}$ & ANLYREFMD & $\mathrm{O}$ \\
\hline L.03 & $\mathrm{L}$ & Analytical method & anMethType & Analytical method type & xs:string (5) & $\mathrm{S}$ & ANLYTYP & M \\
\hline L.04 & $\mathrm{L}$ & Analytical method & anMethCode & Analytical method code & CompoundType & $\mathrm{C}$ & ANLYMD & M \\
\hline L.05 & L & Analytical method & anMethText & Analytical method text & xs:string (250) & $\mathrm{s}$ & & DM \\
\hline L.06 & L & Analytical method & anMethInfo & $\begin{array}{l}\text { Additional information on the analytical } \\
\text { method }\end{array}$ & CompoundType & C & & $\mathrm{O}$ \\
\hline M.01 & M & Result & resId & Result identification code & xs:string (100) & $\mathrm{s}$ & & M \\
\hline M.02 & $M$ & Result & accredProc & $\begin{array}{l}\text { Accreditation procedure for the analytical } \\
\text { method }\end{array}$ & xs:string (5) & $\mathrm{S}$ & MDACC & $M$ \\
\hline M.03 & M & Result & resUnit & Result unit & xs:string (5) & $\mathrm{S}$ & UNIT & DM \\
\hline M.04 & M & Result & resLOD & Result LOD & xs:double & $\mathrm{S}$ & & DM \\
\hline M.05 & M & Result & resLOQ & Result LOQ & xs:double & $\mathrm{S}$ & & $\mathrm{R}, \mathrm{DM}$ \\
\hline M.06 & M & Result & resLLWR & Result lower limit of the working range & xs:double & $\mathrm{S}$ & & 0 \\
\hline M.07 & M & Result & resULWR & Result upper limit of the working range & xs:double & $\mathrm{S}$ & & $\mathrm{O}$ \\
\hline M.08 & M & Result & CCalpha & CC alpha & xs:double & $\mathrm{S}$ & & DM \\
\hline M.09 & M & Result & CCbeta & CC beta & xs:double & $\mathrm{s}$ & & DM \\
\hline M.10 & M & Result & resVal & Result value & xs:double & $\mathrm{S}$ & & DM \\
\hline M.11 & M & Result & resValRec & Result value recovery rate & xs:double & $\mathrm{S}$ & & $\mathrm{O}$ \\
\hline M.12 & M & Result & resValRecCorr & Result value corrected for recovery & xs:string (1) & $\mathrm{S}$ & YESNO & $\mathrm{O}$ \\
\hline M.13 & M & Result & exprResPerc & Expression of result percentage & CompoundType & C & & DR \\
\hline M.14 & M & Result & exprResType & Expression of result type & xs:string (5) & $\mathrm{s}$ & EXPRRES & 0 \\
\hline M.15 & M & Result & resQualValue & Result qualitative value & xs:string (3) & $\mathrm{s}$ & POSNEG & DM \\
\hline M.16 & M & Result & resType & Type of result & xs:string (3) & $\mathrm{S}$ & VALTYP & M \\
\hline M.17 & M & Result & resValUncert & Result value uncertainty & xs:double & $\mathrm{S}$ & & DR \\
\hline M.18 & M & Result & resValUncertSD & $\begin{array}{l}\text { Result value uncertainty Standard } \\
\text { deviation }\end{array}$ & xs:double & $\mathrm{S}$ & & DR \\
\hline M.20 & M & Result & resinfo & Additional information on the result & CompoundType & $\mathrm{C}$ & & $\mathrm{O}$ \\
\hline N.01 & $\mathrm{N}$ & Evaluation & evalLowLimit & Limit for the result evaluation & xs:double & $\mathrm{S}$ & & DR \\
\hline N.03 & $\mathrm{N}$ & Evaluation & evallimitType & Type of limit for the result evaluation & xs:string (5) & $\mathrm{S}$ & LMTTYP & $\mathrm{DR}, \mathrm{DM}$ \\
\hline N.04 & $\mathrm{N}$ & Evaluation & evalCode & Evaluation of the result & xs:string (5) & $\mathrm{S}$ & RESEVAL & M \\
\hline N.05 & $\mathrm{N}$ & Evaluation & actTakenCode & Action Taken & $x s$ string (1) & $\mathrm{R}$ & ACTION & DM \\
\hline N.06 & $\mathrm{N}$ & Evaluation & evalInfo & Additional information on the evaluation & CompoundType & $\mathrm{C}$ & & M \\
\hline
\end{tabular}

a): $S$, simple; $R$, repeatable; $C$, compound.

b): $M$, mandatory; $R$, recommended; $\mathrm{O}$, optional; $\mathrm{DM}$, dependent mandatory; $\mathrm{DR}$, dependent recommended.

The present document has been produced and adopted by the bodies identified above as author(s). This task has been carried out exclusively by the author(s) in the context of a contract between the European Food Safety Authority and the author(s), awarded following a tender procedure. The present document is published complying with the transparency principle to which the Authority is subject. It may not be considered as an output adopted by the Authority. The European Food Safety Authority reserves its rights, view and position as regards the issues addressed and the conclusions reached in the present document, without prejudice to the rights of the author(s). 


\subsection{Encoding and mapping}

The mapping results are presented in tables 3 to 10 for VMPR.

The encoding results of controlled terminologies from the data sources to SSD2 catalogues are presented in tables 11 to 17.

There are some fields with terms that are not necessarily dependent of the national authority itself and their official control plans, and could remain the same for more than one year of report. These terms are automatically filled in by the system (Auto-fill column), since they are previously known. For example, since all data received are from national authorities, the SSD2 field for the reporting country information (D.02) will be 'PT' for Portugal.

In the column SIPACE are indentified the terms that identifies the corresponding field present in the national authority system, in which data is retrieved.

The column INIAV-NAUTILUS refers to information sent from the existing Laboratory Information Management System.

The format in which the data is sent to be processed by the "alimentos PT.ON.DATA" is in Excel. 
Table 3: Residues of veterinary medicinal products (VMPR) sections A to B

\begin{tabular}{|c|c|c|c|c|c|c|c|c|c|c|c|c|c|c|c|c|c|}
\hline Element code & Section code & Section & Element name & Element label & Type & $\stackrel{S / R / C}{\square}$ & M & Controlled terminology & Description & $\begin{array}{c}\text { Veterinary } \\
\text { medicinal product } \\
\text { residues data } \\
\text { collection }\end{array}$ & SIPACE_FMR & $\begin{array}{r}\text { SIPACE_FMR2 } \\
v\end{array}$ & 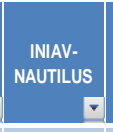 & Auto-Fill & $\begin{array}{r}\text { European } \\
\text { Commission } \\
\text { Database }\end{array}$ & $\stackrel{\text { EC_DB }}{-}$ & Obs. \\
\hline A.01 & A & Local organisation I & localorgld & $\begin{array}{l}\text { Local } \\
\text { organisation } \\
\text { identification } \\
\text { code }\end{array}$ & xs:string(100) S & s & & & $\begin{array}{l}\text { Unique identification of the local or regional or } \\
\text { national organisition (Compentent Authority or } \\
\text { company affiliate) requesting the analysis. }\end{array}$ & optional & & & Cliente & & & & \\
\hline A.02 & A & Local organisation I & localOrgCountry & $\begin{array}{l}\text { Local } \\
\text { organisation } \\
\text { country }\end{array}$ & xs:string(2) & s & & COUNTRY & $\begin{array}{l}\text { Country where the local organisation is placed. } \\
\text { (ISO } 3166-1-\text { alpha-2). }\end{array}$ & optional & & & & PT & & & \\
\hline A.03 & A & Local organisation I & localorglnto & $\begin{array}{l}\text { Local } \\
\text { organisation } \\
\text { additional } \\
\text { information }\end{array}$ & CompoundType C & C & & & $\begin{array}{l}\text { Addititional specific information and comments on } \\
\text { the local organisation depending on specific } \\
\text { requirements of the different data collection } \\
\text { domains. }\end{array}$ & optional & & & & & & & \\
\hline B.01 & B & $\begin{array}{l}\text { Sampling } \\
\text { programme }\end{array}$ & progld & $\begin{array}{l}\text { Sampling } \\
\text { programme } \\
\text { identification } \\
\text { code }\end{array}$ & xs:string(100) S & s & & & $\begin{array}{l}\text { Unique identification code of the programme or } \\
\text { project for which the sampling unit was taken. }\end{array}$ & optional & & & Protocolo & & & & \\
\hline B.02 & B & $\begin{array}{l}\text { Sampling } \\
\text { programme }\end{array}$ & proglegalRef & $\begin{array}{l}\text { Programme legal } \\
\text { reference }\end{array}$ & xs:string(5) R & $\mathrm{R}$ & & LEGREF & $\begin{array}{l}\text { Reference to the legislation for the programme } \\
\text { defined by programme code. Reference to the } \\
\text { legislation on what to sample, how to evaluate the } \\
\text { sample etc. }\end{array}$ & recommended & & & & & & & \\
\hline B.03 & B & $\begin{array}{l}\text { Sampling } \\
\text { programme }\end{array}$ & sampStrategy & $\begin{array}{l}\text { Sampling } \\
\text { strategy }\end{array}$ & xs:string(5) & s & & SAMPSTR & $\begin{array}{l}\text { Sampling strategy describe how the sample was } \\
\text { selected (ref. EUROSTAT - Typology of sampling } \\
\text { strategy performed in the programme or project } \\
\text { identified by programme code (e.g. objective and } \\
\text { selective sampling)). }\end{array}$ & mandatory & & & & ST10A & & & \\
\hline B. 04 & B & $\begin{array}{l}\text { Sampling } \\
\text { programme }\end{array}$ & progType & Programme type & xs:string(5) & s & & PRGTYP & $\begin{array}{l}\text { Indicate the type of programme for which the } \\
\text { samples have been collected (National, EU } \\
\text { programme, Total diet study, Control and } \\
\text { eradication programme). }\end{array}$ & mandatory & & & & K005A & & & \\
\hline B. 05 & B & $\begin{array}{l}\text { Sampling } \\
\text { programme }\end{array}$ & sampMethod & Sampling method & xs:string(5) & s & & $\underline{\text { SAMPMD }}$ & $\begin{array}{l}\text { Reference to the method for sampling (e.g. EU } \\
\text { legislation). }\end{array}$ & optional & & & & & & & \\
\hline B.06 & B & $\begin{array}{l}\text { Sampling } \\
\text { programme }\end{array}$ & sampler & Sampler & xs:string(5) & s & & SAMPLR & $\begin{array}{l}\text { Define which organisation (private or public) is } \\
\text { performing the sample. }\end{array}$ & mandatory & & & & DGAV & & & \\
\hline B.07 & B & $\begin{array}{l}\text { Sampling } \\
\text { programme }\end{array}$ & sampPoint & Sampling point & xs:string(5) $\mathrm{S}$ & s & & SAMPNT & $\begin{array}{l}\text { Point, in the food chain, where the sample was } \\
\text { taken. (See Doc. ESTAT/F5/ES/155 "Data } \\
\text { dictionary of activities of the establishments"). }\end{array}$ & mandatory & FaseCadeia & & & & Sampling & & \\
\hline B. 08 & B & $\begin{array}{l}\text { Sampling } \\
\text { programme }\end{array}$ & proglinio & $\begin{array}{l}\text { Additional } \\
\text { sampling } \\
\text { piogram } \\
\text { information }\end{array}$ & CompoundType C & & & & 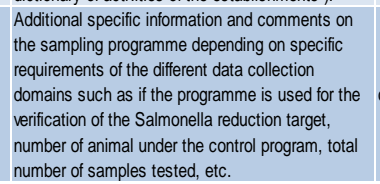 & optional & & & & & & & \\
\hline
\end{tabular}

The present document has been produced and adopted by the bodies identified above as author(s). This task has been carried out exclusively by the author(s) in the context of a contract between the European Food Safety Authority and the author(s), awarded following a tender procedure. The present document is published complying with the transparency principle to which the Authority is subject. It may not be considered as an output adopted by the Authority. The European Food Safety Authority reserves its rights, view and position as regards the issues addressed and the conclusions reached in the present document, without prejudice to the rights of the author(s). 
Table 4: Residues of veterinary medicinal products (VMPR) sections $C$ to $D$

\begin{tabular}{|c|c|c|c|c|c|c|c|c|c|c|c|c|c|c|c|c|c|}
\hline Element code & Section code & Section & Element name & Element label & Type & $\stackrel{S / R / C}{V}$ & m & Controlled terminology & Description & $\begin{array}{c}\text { Veterinary } \\
\text { medicinal product } \\
\text { residues data } \\
\text { collection }\end{array}$ & SIPACE_FMR & SIPACE_FMR2 & 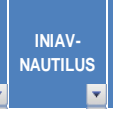 & Auto-Fill & $\begin{array}{r}\text { European } \\
\text { Commision } \\
\text { Database }\end{array}$ & EC_DB & Obs. \\
\hline c.01 & c & Sampling event & sampEventld & $\begin{array}{l}\text { Sampling event } \\
\text { identification } \\
\text { code }\end{array}$ & xs:string(100) & s & & & $\begin{array}{l}\text { Unique identification of the sampling event. The } \\
\text { entity yepresenting the samplininunitextracted at } \\
\text { certain time from the sampled population, whose } \\
\text { chemical or microbilogical properties are the } \\
\text { target of the sampling. }\end{array}$ & optional & & & & & & & \\
\hline c.02 & c & Sampling event & sampUnitype & $\begin{array}{l}\text { Sampling unit } \\
\text { type }\end{array}$ & xs:string(5) & s & & $\underline{\text { SAMPUNTYP }}$ & $\begin{array}{l}\text { Define the type of sampling unit taken in this event: } \\
\text { a batch, an animal, a flock, a herd, etc. }\end{array}$ & mandatory & UnidadeAmostra & & & & & & \\
\hline c.03 & c & Sampling event & sampUnitsize & $\begin{array}{l}\text { Sampling unit } \\
\text { size }\end{array}$ & xs:double & s & & & It contains the size/amount of the sampling unit. & optional & & & & & & & \\
\hline C.04 & c & Sampling event & sampUnitSizeUnit & $\begin{array}{l}\text { Sampling unit } \\
\text { size unit }\end{array}$ & xs:string(5) & s & & UNIT & $\begin{array}{l}\text { It contains the Unit in which the sampling unit size } \\
\text { is expressed. }\end{array}$ & dependent mandatory & & & & & & & \\
\hline c.05 & c & Sampling event & sampUnitds & $\begin{array}{l}\text { Other sampling } \\
\text { unit } \\
\text { identifications }\end{array}$ & CompoundType & ec & & & $\begin{array}{l}\text { Additional identification codes for the sampling } \\
\text { unit, at a more detatele level than the sampling } \\
\text { event ID e.g. herd code or animal ear tag number. }\end{array}$ & mandatory & $\begin{array}{l}\text { Identificacaolndiv } \\
\text { idualAnimais }\end{array}$ & & & 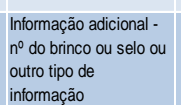 & & & \\
\hline C.06 & c & Sampling event & sampEventinfo & $\begin{array}{l}\text { Additional } \\
\text { sampling event } \\
\text { information }\end{array}$ & CompoundType & ec & & & $\begin{array}{l}\text { Additional intormation on the sampling event } \\
\text { depending on specific requirements of the different } \\
\text { data collection domains such as status of the } \\
\text { holdding, the vaccication sutatus, the date and } \\
\text { county of slaughtering, etc. }\end{array}$ & optional & & & & & & & \\
\hline D. 01 & D & Sample taken & sampld & $\begin{array}{l}\text { Sample taken } \\
\text { identification } \\
\text { code }\end{array}$ & xs:string(100) & s & M & & Identification code of the sample taken. & mandatory & \$ld & & & & & & \\
\hline D. 02 & D & Sample taken & repCountry & $\begin{array}{l}\text { Reporting } \\
\text { country }\end{array}$ & xs:string(2) s s & s & & COUNTRY & $\begin{array}{l}\text { The county the reported data refer to (ISO } 3166-1 \text { - } \\
\text { alpha-2). }\end{array}$ & optional & & & & & & & \\
\hline D.03 & D & Sample taken & sampCountry & $\begin{array}{l}\text { Country of } \\
\text { sampling }\end{array}$ & $x$ s:string(2) & s & M & $\underline{\text { COUNTRY }}$ & $\begin{array}{l}\text { Country where the sample was taken for laboratory } \\
\text { testing (ISO 3166-1-alpha-2). }\end{array}$ & mandatory & & & & PT & & & \\
\hline D. 04 & D & Sample taken & sampArea & Area of sampling & xs:string(5) & s & & NUTS & $\begin{array}{l}\text { Area where the sample was collected } \\
\text { (Nomenclature of fertitorial units for statistics - } \\
\text { NuTS - ooding system valid only for EEA and } \\
\text { Switzerland). }\end{array}$ & optional & DAV & Regiāo & & & & & \\
\hline D.05 & D & Sample taken & repYear & Reporting year & $x$ s:integer(4) & s & & & The year the reported data refer to. & n/a & & & & & & & \\
\hline D. 06 & D & Sample taken & sampY & Year of sampling & $x$ s:integer(4) & s & M & & $\begin{array}{l}\text { Year of sampling. In case the sampling has been } \\
\text { performed over a period of time the start date (as } \\
\text { year) of sampling should be reported. }\end{array}$ & mandatory & DataColheita & & $\begin{array}{l}\text { Data de } \\
\text { colheita }\end{array}$ & & & & \\
\hline D. 07 & D & Sample taken & sampM & $\begin{array}{l}\text { Month of } \\
\text { sampling }\end{array}$ & $x$ s:integer(2) & s & & & $\begin{array}{l}\text { Month of sampling. In case the sampling has been } \\
\text { performed vere a period of time the start date (as } \\
\text { month) of sampling should be reportede. }\end{array}$ & optional & DataColheita & & $\begin{array}{l}\text { Data de } \\
\text { colheita }\end{array}$ & & & & \\
\hline D. 08 & D & Sample taken & sampD & Day of sampling & $x$ s:integer(2) & s & & & $\begin{array}{l}\text { Day of sampling. In case the sampling has been } \\
\text { petormed over a period of time the start date (as } \\
\text { day) of sampling should be reported. }\end{array}$ & optional & DataColheita & & $\begin{array}{l}\text { Data de } \\
\text { colheita }\end{array}$ & & & & \\
\hline D.09 & D & Sample taken & sampSize & $\begin{array}{l}\text { Sample taken } \\
\text { size }\end{array}$ & xs:double & s & & & Total size/amount of the sample taken. & optional & & & & & & & \\
\hline D.10 & D & Sample taken & sampSizeUnit & $\begin{array}{l}\text { Sample taken } \\
\text { size unit }\end{array}$ & xs:string(5) & s & & $\underline{\mathrm{UNIT}}$ & $\begin{array}{l}\text { Unit in which the size/amount of the sample taken } \\
\text { is expressed. }\end{array}$ & dependent mandatory & & & & & & & \\
\hline D. 11 & D & Sample taken & samplinio & $\begin{array}{l}\text { Additional } \\
\text { Sample taken } \\
\text { information }\end{array}$ & CompoundType & ec & & & $\begin{array}{l}\text { Additional intormation on the sample taken } \\
\text { depending on specific requirements of the different } \\
\text { data collection domains (e.g. day of arvival in the } \\
\text { lab). }\end{array}$ & dependent mandatory & & & & & & & \\
\hline
\end{tabular}

The present document has been produced and adopted by the bodies identified above as author(s). This task has been carried out exclusively by the author(s) in the context of a contract between the European Food Safety Authority and the author(s), awarded following a tender procedure. The present document is published complying with the transparency principle to which the Authority is subject. It may not be considered as an output adopted by the Authority. The European Food Safety Authority reserves its rights, view and position as regards the issues addressed and the conclusions reached in the present document, without prejudice to the rights of the author(s). 
Table 5: Residues of veterinary medicinal products (VMPR) section $E$

\begin{tabular}{|c|c|c|c|c|c|c|c|c|c|c|c|c|c|c|c|c|c|}
\hline Element code & Section code & Section & Element name & Element label & Type & $\begin{array}{r}S / R / C \\
.\end{array}$ & M & Controlled terminology & Description & $\begin{array}{c}\text { Veterinary } \\
\text { medicinal product } \\
\text { residues data } \\
\text { collection }\end{array}$ & SIPACE_FMR & SIPACE FMR2 & $\begin{array}{l}\text { INAAV- } \\
\text { NAUTILUS } \\
\end{array}$ & Auto-Fill & $\begin{array}{c}\text { European } \\
\text { Commission } \\
\text { Database }\end{array}$ & EC_DB & obs. \\
\hline E.01 & E & Matrix sampled & sampMatype & Type of matrix & 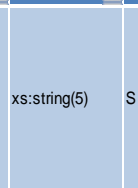 & s & M & MTXTYP & 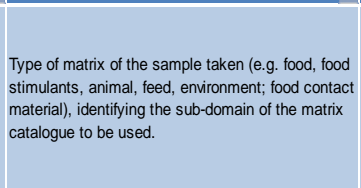 & mandatory & $\begin{array}{l}\text { TipoProdutoNi } \\
\text { vel1 (Type of } \\
\text { matrix; Coded } \\
\text { description of } \\
\text { the matrix of } \\
\text { the sample } \\
\text { taken) }\end{array}$ & & & & $\begin{array}{l}\text { Species/Prod } \\
\text { ucts }\end{array}$ & & \\
\hline E.02 & E & Matrix sampled & sampMatCode & $\begin{array}{l}\text { Coded } \\
\text { description of the } \\
\text { matrix of the } \\
\text { sample taken }\end{array}$ & CompoundType C & & M & $\underline{M T X}$ & $\begin{array}{l}\text { Description of the sample taken characteristics } \\
\text { using the FoodEx2 catalogue. }\end{array}$ & mandatory & TipoProdutoNiv & TipoprodutoNive 1 & Matriz & & Matrix & & \\
\hline E.03 & E & Matrix sampled & sampMatText & $\begin{array}{l}\text { Text description } \\
\text { of the matrix of } \\
\text { the sample taken }\end{array}$ & xs:string(250) S & s & & & $\begin{array}{l}\text { Description of the sample taken characteristics } \\
\text { using tree text. }\end{array}$ & $\begin{array}{l}\text { recommended }+ \\
\text { dependent mandatory }\end{array}$ & $\begin{array}{l}\text { TipoprodutoNi } \\
\text { vel1 (Type of } \\
\text { matrix Coded } \\
\text { description of } \\
\text { the matrix of } \\
\text { the sample } \\
\text { taken) }\end{array}$ & TipoProdutoNivel2 & & & Matrix & & \\
\hline E.04 & E & Matrix sampled & origCountry & $\begin{array}{l}\text { Country of origin } \\
\text { of the sample } \\
\text { taken }\end{array}$ & xs:string(2) $\mathrm{s}$ & $\mathrm{s}$ & & COUNTRY & $\begin{array}{l}\text { Country of origin of the sample taken (ISO 3166-1. } \\
\text { alpha-2 country code). }\end{array}$ & mandatory & $\begin{array}{l}\text { Pais de } \\
\text { Origem?????/Ex } \\
\text { ploracaoPais }\end{array}$ & & & $\begin{array}{l}\text { Confirmar se a DGAV } \\
\text { não tem um campo } \\
\text { com esta intormação }\end{array}$ & & & \\
\hline E.05 & E & Matrix sampled & origarea & $\begin{array}{l}\text { Area of origin of } \\
\text { the sample taken }\end{array}$ & xs:string(5) $s$ & s & & NUTS & 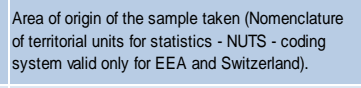 & optional & & & & & & & \\
\hline E.06 & E & Matrix sampled & origfishAreaCode & $\begin{array}{l}\text { Area of origin for } \\
\text { fisheries or } \\
\text { aquaculture } \\
\text { activities code of } \\
\text { the sample taken }\end{array}$ & $x$ s:string(10) S & s & & FAREA & $\begin{array}{l}\text { Fisheries or aquaculture area speiting the origin } \\
\text { of the sample (FAO Fisheries areas). }\end{array}$ & optional & & & & & & & \\
\hline E.07 & E & Matrix sampled & origFishAreaText & $\begin{array}{l}\text { Area of origin for } \\
\text { fisheries or } \\
\text { aquaculture } \\
\text { activities text of } \\
\text { the sample taken }\end{array}$ & xs:string(250) S & s & & & Fisheries or aquaculture area specified in free text. & t. optional & & & & & & & \\
\hline E.08 & E & Matrix sampled & procCounty & $\begin{array}{l}\text { Country of } \\
\text { processing of the } \\
\text { sample taken }\end{array}$ & xs:string(2) & s & & COUNTRY & $\begin{array}{l}\text { Country where the food was processed (ISO } 3166 \text { - } \\
\text { 1-alpha-2). }\end{array}$ & optional & & & & & & & \\
\hline E.09 & E & Matrix sampled & procarea & $\begin{array}{l}\text { Area of } \\
\text { processing of the } \\
\text { sample taken }\end{array}$ & xs:string(5) & s & & NUTS & $\begin{array}{l}\text { Area of product processing (Nomenclature of } \\
\text { teritorial units for statistics - NUTS - coding } \\
\text { system valid only for EEA and Switzerland). }\end{array}$ & optional & & & & & & & \\
\hline E.10 & E & Matrix sampled & sampMattino & $\begin{array}{l}\text { Additional } \\
\text { intormation on } \\
\text { the matrix } \\
\text { sampled }\end{array}$ & CompoundType C & & & & $\begin{array}{l}\text { Additional specifici intormation and comments on } \\
\text { the mantrix sampled, depending on specific } \\
\text { requirements of the different data collection } \\
\text { domanis. }\end{array}$ & optional & & & & & & & \\
\hline
\end{tabular}

The present document has been produced and adopted by the bodies identified above as author(s). This task has been carried out exclusively by the author(s) in the context of a contract between the European Food Safety Authority and the author(s), awarded following a tender procedure. The present document is published complying with the transparency principle to which the Authority is subject. It may not be considered as an output adopted by the Authority. The European Food Safety Authority reserves its rights, view and position as regards the issues addressed and the conclusions reached in the present document, without prejudice to the rights of the author(s). 
Table 6: Residues of veterinary medicinal products (VMPR) sections $\mathrm{F}$ to $\mathrm{H}$

\begin{tabular}{|c|c|c|c|c|c|c|c|c|c|c|c|c|c|c|c|c|c|}
\hline Element code & Section code & Section & Element name & Element label & Type & $\stackrel{S I R C}{2}$ & M & Controlled terminology & Description & $\begin{array}{c}\text { Veterinary } \\
\text { medicinal product } \\
\text { residues adata } \\
\text { collection }\end{array}$ & $\begin{array}{r}\text { SIPACE FMR } \\
\sim\end{array}$ & SIPACE_FMR2 & $\begin{array}{r}\text { INAVV. } \\
\text { NAUTILUS } \\
\end{array}$ & Auto-Fill & 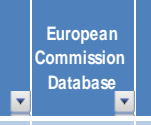 & ${ }^{E C D D B}$ & Obs. \\
\hline F.01 & $\mathrm{F}$ & Sample analysed & sampAnld & $\begin{array}{l}\text { Sample analysed } \\
\text { identification } \times \\
\text { code }\end{array}$ & xs:string(100) & s & & & $\begin{array}{l}\text { Identification code of the analysed sample, by } \\
\text { default the same as sampld. }\end{array}$ & optional & & & Amostrane & & & & \\
\hline $\mathrm{F} .02$ & $\mathrm{~F}$ & Sample analysed & sampAnRertime & $\begin{array}{l}\text { Sample analysis } \\
\text { reference time }\end{array}$ & xs:string(5) & s & & REFTM & 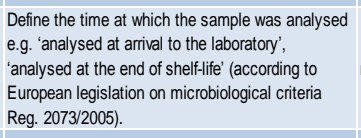 & n/a & & & & & & & \\
\hline F.03 & $\mathrm{F}$ & Sample analysed & analysisY & Year of analysis $x$ & $x$ xs:integer(4) & s & M & & Year when the analysis was completed. & mandatory & & & $\begin{array}{l}\text { Data de } \\
\text { autorização }\end{array}$ & & & & \\
\hline F.04 & $\mathrm{F}$ & Sample analysed & analysisM & $\begin{array}{l}\text { Month of } \\
\text { analysis }\end{array}$ & xs:integer(2) & s & & & Month when the analysis was completed. & optional & & & $\begin{array}{l}\text { Data de } \\
\text { autorização }\end{array}$ & & & & \\
\hline F.05 & F & Sample analysed & analysisD & Day of analysis $x$ & xs:integer(2) & s & & & Day when the analysis was completed. & optional & & & $\begin{array}{l}\text { Data de } \\
\text { autorização }\end{array}$ & & & & \\
\hline F.06 & $\mathrm{F}$ & Sample analysed & sampAnlnio & $\begin{array}{l}\text { Additional } \\
\text { intormation on } \\
\text { the sample } \\
\text { analysed }\end{array}$ & CompoundType C & $c$ & & & $\begin{array}{l}\text { Additional specific information and comments on } \\
\text { the sample analysed depending on specific } \\
\text { requirements of the different data collection } \\
\text { domains. }\end{array}$ & optional & & & & & & & \\
\hline G.01 & G & Matrix analysed & anMatcode & $\begin{array}{l}\text { Coded } \\
\text { description of the } 0 \\
\text { analysed matrix }\end{array}$ & Compoundtype & $c$ & & MTX & $\begin{array}{l}\text { Encoding of the matrix analysed characteristics } \\
\text { using the FoodEx catalogue. By defaut this } \\
\text { lement has the same value as "sampMaticode". }\end{array}$ & dependent mandatory & & & Matriz & & & & \\
\hline G.02 & G & Matrix analysed & anMatText & $\begin{array}{l}\text { Text description } \\
\text { of the mattix } \\
\text { analysed }\end{array}$ & xs:string(250) s & s & & & $\begin{array}{l}\text { Description of the matrix analysed characteristics } \\
\text { using tree text. }\end{array}$ & $\begin{array}{l}\text { dependent } \\
\text { recommended }\end{array}$ & & & Matriz & & & & \\
\hline G.03 & G & Matrix analysed & anMathnio & $\begin{array}{l}\text { Additional } \\
\text { information on } \\
\text { the analysed } \\
\text { matrix }\end{array}$ & CompoundType C & c & & & $\begin{array}{l}\text { Additional specific intormation and commentits on } \\
\text { the matrix analysed depending on specific } \\
\text { requirements of the different data collection } \\
\text { domains. }\end{array}$ & optional & Observacoes & & & & & & \\
\hline H.01 & H & $\begin{array}{l}\text { Sample analysed } \\
\text { portion }\end{array}$ & anPortseq & $\begin{array}{l}\text { Sample analysed } \\
\text { portion sequence }\end{array}$ & xs:string(100) s & s & & & $\begin{array}{l}\text { Sequence number }(\text { e.g. } 1,2,3) \text { refecting the } \\
\text { sample analysed portion actually under analysis. } \\
\text { The defaut value is } 1 \text {. }\end{array}$ & optional & & & & & & & \\
\hline H.02 & H & $\begin{array}{l}\text { Sample analysed } \\
\text { portion }\end{array}$ & anPortSize & $\begin{array}{l}\text { Sample analysed } \\
\text { portion size }\end{array}$ & xs:double & s & & & $\begin{array}{l}\text { Size/amount of the sample analysed portion, i.e. } \\
\text { amount of sample weight for analysis (weight of } \\
\text { test portion). }\end{array}$ & optional & & & & & & & \\
\hline H.03 & $\mathrm{H}$ & $\begin{array}{l}\text { Sample analysed } \\
\text { portion }\end{array}$ & anPortSizeUnit & $\begin{array}{l}\text { Sample analysed } \\
\text { portion size unit }\end{array}$ & xs:String(5) & s & & UNIT & $\begin{array}{l}\text { Unit in which the size of the sample analysed } \\
\text { portion is expressed. }\end{array}$ & dependent mandatory & & & & & & & \\
\hline H.04 & H & $\begin{array}{l}\text { Sample analysed } \\
\text { portion }\end{array}$ & anPorthnfo & $\begin{array}{l}\text { Additional } \\
\text { information on } \\
\text { the sample } \\
\text { analysed portion }\end{array}$ & Compoundtype $C$ & c & & & $\begin{array}{l}\text { Additional information and comments on the } \\
\text { sample analysed portion depending on specific } \\
\text { requirements of the dififerent data collection } \\
\text { domains. }\end{array}$ & optional & & & & & & & \\
\hline
\end{tabular}

The present document has been produced and adopted by the bodies identified above as author(s). This task has been carried out exclusively by the author(s) in the context of a contract between the European Food Safety Authority and the author(s), awarded following a tender procedure. The present document is published complying with the transparency principle to which the Authority is subject. It may not be considered as an output adopted by the Authority. The European Food Safety Authority reserves its rights, view and position as regards the issues addressed and the conclusions reached in the present document, without prejudice to the rights of the author(s). 
Table 7: Residues of veterinary medicinal products (VMPR) sections I to $\mathrm{K}$

\begin{tabular}{|c|c|c|c|c|c|c|c|c|c|c|c|c|c|c|c|c|c|}
\hline Element code & Section code & Section & Element name & Element label & Type & S/RC & M & Controlled terminology & Description & $\begin{array}{c}\text { Veterinary } \\
\text { medicinal product } \\
\text { residues data } \\
\text { collection }\end{array}$ & SIPACE_FMR & SIPACE FMR2 & $\mid \begin{array}{r}\text { INAVV. } \\
\text { NAUTILUS } \\
\end{array}$ & v & $\begin{array}{c}\text { European } \\
\text { Commission } \\
\text { Database }\end{array}$ & $\stackrel{\text { EC_DB }}{-}$ & Obs. \\
\hline 1.01 & I & Isolate & isolld & $\begin{array}{l}\text { Isolate } \\
\text { identification }\end{array}$ & xs:string(100) & s & & & $\begin{array}{l}\text { Identification code used to group an isolate } \\
\text { identification with antimicrobial susceptibility tests } \\
\text { performed on the same isolate. }\end{array}$ & n/a & & & & & & & \\
\hline 1.02 & I & Isolate & isolParamCode & $\begin{array}{l}\text { Coded } \\
\text { descripition of the } \\
\text { isolate }\end{array}$ & xs:string(15) & s & & PARAM & $\begin{array}{l}\text { Encoding of the isolate parameter code according } \\
\text { to the PARAM catalogue. It is used to report the } \\
\text { speciation or serotyping of the isolate. }\end{array}$ & n/a & & & & & & & \\
\hline 1.03 & 1 & Isolate & isolParamText & $\begin{array}{l}\text { Text description } \\
\text { of the isolate }\end{array}$ & xs:string(250) & s & & & $\begin{array}{l}\text { Description of the isolate parametere (e.g. } \\
\text { speciation/serotyping) using tree text. }\end{array}$ & n/a & & & & & & & \\
\hline 1.04 & I & Isolate & isollnto & $\begin{array}{l}\text { Additional } \\
\text { intormation on } \\
\text { the isolate }\end{array}$ & CompoundType & $c$ & & & $\begin{array}{l}\text { Addititional specififi intormation and comments on } \\
\text { the isolate depending on specific requirements of } \\
\text { the different datat collection domains. }\end{array}$ & n'a & & & & & & & \\
\hline J.01 & J & Laboratory & labld & $\begin{array}{l}\text { Laboratory } \\
\text { identification } \\
\text { code }\end{array}$ & xs:string(50) & s & & & $\begin{array}{l}\text { Identification code of the laboratory (National } \\
\text { laborataty code if avalable). This code should be } \\
\text { nationally unique and consistent through all data } \\
\text { domain transmissions. }\end{array}$ & recommended & Laboratorio & & & & & & \\
\hline J.02 & J & Laboratory & labAccred & $\begin{array}{l}\text { Laboratory } \\
\text { accreditation }\end{array}$ & xs:string(1) & s & & $\underline{\angle A B A C C}$ & $\begin{array}{l}\text { The accreditation status of the laboratory and its } \\
\text { reference proceculue. }\end{array}$ & mandatory & & & & $\begin{array}{l}\text { LO01A (conforme o } \\
\text { laboratório que envia os } \\
\text { resultados neste caso } \\
\text { como é só o INIAV O } \\
\text { código pode estar pré- }\end{array}$ & & & \\
\hline J.03 & j & Laboratory & labCountry & $\begin{array}{l}\text { Laboratory } \\
\text { country }\end{array}$ & xs:string(2) & s & & COUNTRY & $\begin{array}{l}\text { Country where the laboratory is located (ISO } 3166 \text { - } \\
\text { 1-alpha-2). }\end{array}$ & optional & & & & $\begin{array}{l}\text { PT ou conforme o } \\
\text { laboratório que enviva os } \\
\text { resultados neste caso } \\
\text { como és so o NIAV o } \\
\text { código pode estar pré- } \\
\text { preenchido }\end{array}$ & & & \\
\hline J.04 & J & Laboratory & lablinio & $\begin{array}{l}\text { Additional } \\
\text { information on } \\
\text { the laboratory }\end{array}$ & CompoundType & $c$ & & & $\begin{array}{l}\text { Additional specific intormation and comments on } \\
\text { the laboratory (e.g. total humber of fisolates } \\
\text { available in the laboratory) depending on speciic } \\
\text { requirements of the different data collection } \\
\text { domains. }\end{array}$ & optional & & & & & & & \\
\hline K.01 & k & Parameter & paramType & $\begin{array}{l}\text { Type of } \\
\text { parameter }\end{array}$ & xs:String(5) & s & M & PARAMTYP & $\begin{array}{l}\text { Define if the parameter reported is an individual } \\
\text { residue/analyte, a summed residue definition or } \\
\text { part of a summed residue definition. }\end{array}$ & mandatory & Parametro & & & $\begin{array}{l}\text { PO01A - Está } \\
\text { dependente do } \\
\text { parâmetro analisado } \\
\text { (em principio será } \\
\text { sempre individual) }\end{array}$ & & & $\begin{array}{l}\text { It will be } \\
\text { elaborate a } \\
\text { correspondence } \\
\text { table (CT) }\end{array}$ \\
\hline K.02 & k & Parameter & paramCode & $\begin{array}{l}\text { Coded } \\
\text { description of the } \\
\text { parameter }\end{array}$ & CompoundType & $c$ & M & PARAM & $\begin{array}{l}\text { Encoding of the parameterlanalyte according to the } \\
\text { PARAM catalogue. }\end{array}$ & mandatory & Parametro & & $\begin{array}{l}\begin{array}{l}\text { Metodologia } \\
\text { analise* }\end{array} \\
\text { Substâncias }\end{array}$ & & Substances & & Info trom LAB \\
\hline K.03 & k & Parameter & paramText & Parameter text & xs:string(250) & s & & & Description of the parameter/analyte using free & dependent mandatory & & & & & & & \\
\hline
\end{tabular}

The present document has been produced and adopted by the bodies identified above as author(s). This task has been carried out exclusively by the author(s) in the context of a contract between the European Food Safety Authority and the author(s), awarded following a tender procedure. The present document is published complying with the transparency principle to which the Authority is subject. It may not be considered as an output adopted by the Authority. The European Food Safety Authority reserves its rights, view and position as regards the issues addressed and the conclusions reached in the present document, without prejudice to the rights of the author(s). 
Table 8: Residues of veterinary medicinal products (VMPR) sections $L$ to $M$

\begin{tabular}{|c|c|c|c|c|c|c|c|c|c|c|c|c|c|c|c|c|c|}
\hline Element code & Section code & Section & Element name & Element label & Type & $\stackrel{S / R C}{-}$ & ${ }^{\mathrm{M}}$ & Controlled terminology & Description & $\begin{array}{c}\text { Veterinary } \\
\text { medicinal product } \\
\text { residues data } \\
\text { collection }\end{array}$ & SIPACE_FMR & SIPACE FMR2 & 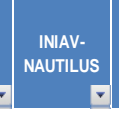 & Auto-Fill & $\begin{array}{c}\text { European } \\
\text { Commission } \\
\text { Database }\end{array}$ & EC_DB & obs. \\
\hline L.01 & L & Analytical method a & anMethRefld & $\begin{array}{l}\text { Analytical } \\
\text { method } \\
\text { identification }\end{array}$ & xs:string(50) & s & & & Identifier for the method used in the laboratory. & optional & & & & & & & \\
\hline L.02 & L & Analytical method a & $d$ anMethRefCode & $\begin{array}{l}\text { Analytical } \\
\text { method reference } \\
\text { code }\end{array}$ & exs:string(5) & s & & ANLYREFMD & $\begin{array}{l}\text { When validated methods are used, the official } \\
\text { reference code should be provided. }\end{array}$ & optional & & & & & & & \\
\hline L.03 & L & Analytical method a & anMethType & $\begin{array}{l}\text { Analytical } \\
\text { method type }\end{array}$ & xs:String(5) & s & & ANLYTYP & Type of analytical method used. & mandatory & & & $\begin{array}{l}\begin{array}{l}\text { Metodologia } \\
\text { análise* }\end{array} \\
\text { Substâncias }\end{array}$ & & & & \\
\hline L.04 & L & Analytical method a & anMethCode & $\begin{array}{l}\text { Analytical } \\
\text { method code }\end{array}$ & xs:string(5) & c & & ANLYMD & $\begin{array}{l}\text { Encoding of the method or instrument used trom } \\
\text { the ANLYMD catalogue. }\end{array}$ & mandatory & & & $\begin{array}{l}\text { Ensaios } \\
\text { revueridos/M } \\
\text { etodologia } \\
\text { analise" }\end{array}$ & & $\begin{array}{l}\text { Screening } \\
\text { Method }\end{array}$ & $\begin{array}{l}\text { Confirmatory } \\
\text { Method }\end{array}$ & TC \\
\hline L.05 & L & Analytical method a & anMethText & $\begin{array}{l}\text { Analytical } \\
\text { method text }\end{array}$ & xs:string(250) & s & & & $\begin{array}{l}\text { Description of the method or instrument using free } \\
\text { text, particularly if 'other' was reported for } \\
\text { 'Analytical method code. }\end{array}$ & dependent mandatory & & & & & & & \\
\hline L.06 & L & Analytical method a & d anMethlinfo & $\begin{array}{l}\text { Additional } \\
\text { intiomation on } \\
\text { the analytical } \\
\text { method }\end{array}$ & CompoundType & c & & & 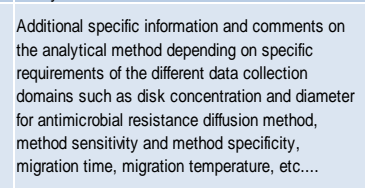 & optional & & & & & & & \\
\hline M.01 & M & Result & resld & $\begin{array}{l}\text { Result } \\
\text { identification } \\
\text { code }\end{array}$ & xs:string(100) & s & M & & 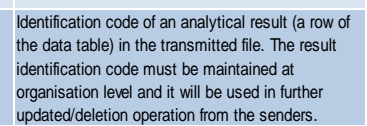 & mandatory & & & & $\begin{array}{l}\text { Criado } \\
\text { automaticamente pelo } \\
\text { sistema }\end{array}$ & & & Auto numbering \\
\hline м.02 & M & Result & accredProc & $\begin{array}{l}\text { Accreditation } \\
\text { procedure for the } \\
\text { analytical } \\
\text { method }\end{array}$ & xs:string(5) & $s$ & & MDACC & $\begin{array}{l}\text { The accreditation status of the analytical method } \\
\text { used and its reference procedure. }\end{array}$ & mandatory & & & $\begin{array}{l}\text { Ensaio } \\
\text { acreditido } \\
\text { (sim/Não) }\end{array}$ & & & & \\
\hline м.03 & M & Result & resUnit & Result unit & xs:string(5) & s & & UNIT & 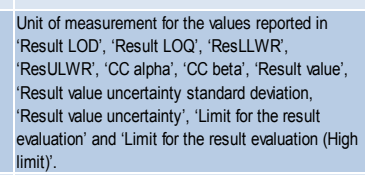 & dependent mandatory & & & $\begin{array}{l}\text { Resultado:Ex } \\
\text { pressáo } \\
\text { resultados } \\
\text { (unidades) }\end{array}$ & & & & \\
\hline M.04 & M & Result & resLOD & Result LOD & xs:double & s & & & $\begin{array}{l}\text { Limit of detection expressed in the unit specififed } \\
\text { by the element Result unit.' }\end{array}$ & dependent mandatory & & & Resultado/ & & & & \\
\hline M.05 & M & Result & resLOQ & Result LOQ & xs:double & s & & & $\begin{array}{l}\text { Limit of quantitication expressed in the unit } \\
\text { specified by the element Result unit'. }\end{array}$ & $\begin{array}{l}\text { recommended }+ \\
\text { dependent mandatory }\end{array}$ & & & Resultado & & & & \\
\hline M.06 & M & Result & resLLWR & $\begin{array}{l}\text { Result lower limit } \\
\text { of the working } \\
\text { range }\end{array}$ & xs:double & $\mathrm{s}$ & & & $\begin{array}{l}\text { Lower limit of the working range expressed in the } \\
\text { unit specified by the element 'Result unit'. }\end{array}$ & optional & & & & & & & \\
\hline M.07 & M & Result & resULWR & $\begin{array}{l}\text { Result upper limit } \\
\text { of the wokking } \\
\text { range }\end{array}$ & it ${ }_{\text {is: double }}$ & s & & & $\begin{array}{l}\text { Upper limit of the working range expressed in the } \\
\text { unit specified by the element 'Resut unitit. }\end{array}$ & optional & & & & & & & \\
\hline
\end{tabular}

The present document has been produced and adopted by the bodies identified above as author(s). This task has been carried out exclusively by the author(s) in the context of a contract between the European Food Safety Authority and the author(s), awarded following a tender procedure. The present document is published complying with the transparency principle to which the Authority is subject. It may not be considered as an output adopted by the Authority. The European Food Safety Authority reserves its rights, view and position as regards the issues addressed and the conclusions reached in the present document, without prejudice to the rights of the author(s). 
Table 9: Residues of veterinary medicinal products (VMPR) section M

\begin{tabular}{|c|c|c|c|c|c|c|c|c|c|c|c|c|c|c|c|}
\hline Element code & Section code & Section & Element name & Element label & Type & $\begin{array}{r}\mathrm{S} / \mathrm{R} / \mathrm{C} \\
-\mathrm{V}\end{array}$ & M Controlled terminology & Description & $\begin{array}{c}\text { Veterinary } \\
\text { medicinal product } \\
\text { residues data } \\
\text { collection }\end{array}$ & SIPACE_FMR SIPACE_FMR2 & $\begin{array}{r}\text { INAVV- } \\
\text { NAUTILUS } \\
-\end{array}$ & Auto-Fill & $\begin{array}{c}\text { European } \\
\text { Commission } \\
\text { Database }\end{array}$ & EC_DB & $\stackrel{ }{\text { Obs. }}$ \\
\hline M.08 & M & Result & CCalpha & CC alpha & xs:double & s & & $\begin{array}{l}\text { CC alpha value (decision limit) expressed in the } \\
\text { unit specified by the element 'Result unit'. }\end{array}$ & dependent mandatory & & $\begin{array}{l}\text { Limite de } \\
\text { decisão } \\
\text { (CCalfa) }\end{array}$ & & $\begin{array}{l}\text { CCalpha- } \\
\text { decision } \\
\text { limits } \\
\text { confirmatory } \\
\text { method }\end{array}$ & & \\
\hline M.09 & M & Result & Ccbeta & $\mathrm{CC}$ beta & xs:double & s & & $\begin{array}{l}\text { CC beta value (detection capability) expressed in } \\
\text { the unit specified by the element 'Result unit'. }\end{array}$ & dependent mandatory & & CCbeta & & $\begin{array}{l}\text { cCbeta- } \\
\text { detection } \\
\text { capability } \\
\text { screening } \\
\text { method }\end{array}$ & & \\
\hline M. 10 & M & Result & resval & Result value & xs:double & s & & $\begin{array}{l}\text { The result of the analytical measure expressed in } \\
\text { the unit specified by the element Result unit. }\end{array}$ & dependent mandatory & & Resultado & & & & \\
\hline M.11 & M & Result & resValRec & $\begin{array}{l}\text { Result value } \\
\text { recovery rate }\end{array}$ & xs:double & s & & $\begin{array}{l}\text { Recovery value associated with the concentration } \\
\text { measurement expressed as a percentage (\%). i.e. } \\
\text { report } 100 \text { tor } 100 \% \text {. }\end{array}$ & optional & & & & & & \\
\hline M.12 & M & Result & resValRecCorr & $\begin{array}{l}\text { Result value } \\
\text { corrected for } \\
\text { recovery }\end{array}$ & xs:string(1) & s & YESNO & $\begin{array}{l}\text { Define if the result value has been corrected for } \\
\text { recovery. }\end{array}$ & optional & & & & & & \\
\hline M.13 & M & Result & expresesPerc & $\begin{array}{l}\text { Expression of } \\
\text { result percentage }\end{array}$ & Compoundtype C & & & 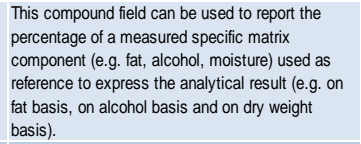 & $\begin{array}{l}\text { dependent } \\
\text { recommended }\end{array}$ & & & & & & \\
\hline M.14 & M & Result & exprRes Type & $\begin{array}{l}\text { Expression of } \\
\text { result type }\end{array}$ & xs:string(5) & s & EXPRRES & $\begin{array}{l}\text { Code to describe how the result has been } \\
\text { expressed: whole weight, tat weight, dy weight, } \\
\text { etc. }\end{array}$ & optional & & & & & & \\
\hline M.15 & M & Result & resoualValue & $\begin{array}{l}\text { Result qualitative } \\
\text { value }\end{array}$ & xs:string(3) & s & POSNEG & $\begin{array}{l}\text { This field should be completed only if the result } \\
\text { value is qualitative e.g. positive present or or 'Rest } \\
\text { negagiveleabsent. In this case the element 'Result } \\
\text { value' should be lef blank. }\end{array}$ & dependent mandatory R & Resultado (Result from lab) & Resultado & & & & \\
\hline M.16 & M & Result & resType & Type of result & xs:string(3) & s & VALTYP & $\begin{array}{l}\text { Indicatet the type of result, whether it could be } \\
\text { quantifiedddetermined or not. }\end{array}$ & mandatory & & Resultado & & & & \\
\hline M.17 & M & Result & resValluncert & $\begin{array}{l}\text { Result value } \\
\text { uncertainty }\end{array}$ & xs:double & s & & $\begin{array}{l}\text { Indicatet the expanded uncertainty value (usually } \\
95 \% \text { confidence interal) associated with the } \\
\text { measurement expressed in the unit reported in the } \\
\text { feld 'Result unit'. }\end{array}$ & $\begin{array}{l}\text { dependent } \\
\text { recommended }\end{array}$ & & & & & & \\
\hline M.18 & M & Result & resValuncertSD & $\begin{array}{l}\text { Result value } \\
\text { uncertainty } \\
\text { Standard } \\
\text { deviation }\end{array}$ & xs:double & s & & $\begin{array}{l}\text { Standard deviation for the uncertainty of } \\
\text { measurement. }\end{array}$ & $\begin{array}{l}\text { dependent } \\
\text { recommended }\end{array}$ & & & & & & \\
\hline M.19 & M & Result & resRefild & $\begin{array}{l}\text { Result reference } \\
\text { identification }\end{array}$ & CompoundType C & & & 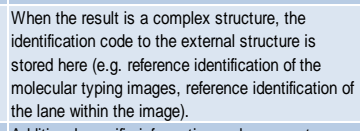 & n/a & & & & & & \\
\hline M.20 & M & Result & resintio & $\begin{array}{l}\text { Additional } \\
\text { intoration on } \\
\text { the result }\end{array}$ & CompoundType C & & & $\begin{array}{l}\text { Additional specific information and commentits on } \\
\text { the reselt section depending on specific } \\
\text { requirements of the different data collection } \\
\text { domanins, such has the referenece type in case of } \\
\text { PFGE, the vector of the numbery of repeat units at } \\
\text { each locus in case of MLVA. }\end{array}$ & optional & & & & & & \\
\hline
\end{tabular}

The present document has been produced and adopted by the bodies identified above as author(s). This task has been carried out exclusively by the author(s) in the context of a contract between the European Food Safety Authority and the author(s), awarded following a tender procedure. The present document is published complying with the transparency principle to which the Authority is subject. It may not be considered as an output adopted by the Authority. The European Food Safety Authority reserves its rights, view and position as regards the issues addressed and the conclusions reached in the present document, without prejudice to the rights of the author(s). 
Table 10: Residues of veterinary medicinal products (VMPR) section $\mathrm{N}$

\begin{tabular}{|c|c|c|c|c|c|c|c|c|c|c|c|c|c|c|c|c|}
\hline Element code & Section code & Section & Element name & Element label & Type & SIRC & M Controlled terminology & Description & $\begin{array}{l}\text { Veterinary } \\
\text { medicinal product } \\
\text { residues data } \\
\text { collection }\end{array}$ & SIPACE FMR & SIPACE FMR2 & $\begin{array}{r}\text { INIAV- } \\
\text { NAUTILUS } \\
-\end{array}$ & Auto-Fill & $\begin{array}{c}\text { European } \\
\text { Commission } \\
\text { Database }\end{array}$ & ECDB & Obs. \\
\hline N.01 & $\mathrm{N}$ & Evaluation & evallowlimit & $\begin{array}{l}\text { Limit for the } \\
\text { result evaluation }\end{array}$ & xs:double & s & & $\begin{array}{l}\text { Report the reference or legal limit, limit or cut-off } \\
\text { value for the parameterlanalyte for the relevant } \\
\text { matrix or the lower level of three-class evaluation } \\
\text { limit analyte. It is expressed in the unit specified } \\
\text { by the element "Result unit". }\end{array}$ & $\begin{array}{l}\text { dependent } \\
\text { recommended }\end{array}$ & & & & & & & \\
\hline N.02 & $\mathrm{N}$ & Evaluation & evallighlimit & $\begin{array}{l}\text { Limit for the } \\
\text { result evaluation } \\
\text { (High limit) }\end{array}$ & xs:double & s & & $\begin{array}{l}\text { Report the higher legal limit of the analyte for the } \\
\text { three-class evaluation limit analyte. It is expressed } \\
\text { in the unit specified by the element "Result unit". }\end{array}$ & & & & & & $\begin{array}{l}\text { Level of } \\
\text { Action }\end{array}$ & & \\
\hline N.03 & $\mathrm{N}$ & Evaluation & evallimitType & $\begin{array}{l}\text { Type of limit for } \\
\text { the result } \\
\text { evaluation }\end{array}$ & xs:string(5) & s & LMTTYP & $\begin{array}{l}\text { Type of legal limit used to evaluate the result. ML, } \\
\text { MRPL, MRL, action limit, cut-of value etc. }\end{array}$ & $\begin{array}{l}\text { dependent } \\
\text { recommended }+ \\
\text { dependent mandatory }\end{array}$ & & & & & & & \\
\hline N.04 & $\mathrm{N}$ & Evaluation & evalcode & $\begin{array}{l}\text { Evaluation of the } \\
\text { result }\end{array}$ & xs:string(5) & s & RESEVAL & $\begin{array}{l}\text { Evaluation of the result. If the result exceeds a limit } \\
\text { specified above or contains the evaluation on } \\
\text { Sampling Event, Sample Taken, or Sample } \\
\text { Analysed as indicated by evalLowLimit (N.01). }\end{array}$ & it mandatory & & & & $\begin{array}{l}\text { Confirmar com a DGAV } \\
\text { se existe algum campo } \\
\text { que alimente este } \\
\text { requisito }\end{array}$ & & & \\
\hline N.05 & $\mathrm{N}$ & Evaluation & actTakenCode & Action Taken & xs:string(1) & R & ACTION & $\begin{array}{l}\text { Describe any follow-up actions taken as a result } \\
\text { higher than the legal limit. }\end{array}$ & dependent mandatory & & & & & & & \\
\hline N.06 & N & Evaluation & evallntio & $\begin{array}{l}\text { Additional } \\
\text { information on } \\
\text { the evaluation }\end{array}$ & CompoundType & & & $\begin{array}{l}\text { Additional specific information and comments on } \\
\text { the evaluation section depending on specific } \\
\text { requirements of the different data collection } \\
\text { domains. }\end{array}$ & mandatory & & & & $\begin{array}{l}\text { Confirmar com a DGAV } \\
\text { se existe algum campo } \\
\text { que alimente este } \\
\text { requisito }\end{array}$ & & & \\
\hline
\end{tabular}


Table 11: Controlled Terminology - Parameters from SIPACE and NAUTILUS (Example)

\begin{tabular}{|c|c|c|c|c|c|c|c|c|}
\hline Parameters_level & SIPACE & INIAV & $\begin{array}{c}\text { Informação } \\
\text { adicional INIAV } \\
(2015 / 2016)\end{array}$ & $\begin{array}{c}\text { Informação } \\
\text { adicional INIAV } \\
(2015 / 2016) 2\end{array}$ & $\begin{array}{c}\text { Informação } \\
\text { adicional INIAV } \\
(2015 / 2016) 3\end{array}$ & SSD2_code & SSD2_text & Obs. \\
\hline & Estilbenos & Estilbenos & & & & RF-00000284-VET & $\begin{array}{l}\text { Stilbenes, stilbene } \\
\text { derivatives }\end{array}$ & \\
\hline Benzestrol & & & & & & RF-00000286-VET & Benzestrol & \\
\hline Cytostatin & & & & & & RF-00000288-VET & Cytostatin & \\
\hline Dienestrol & & Dienestrol (DIE) & Dienestrol (DIE) & & & RF-00000291-VET & Dienestrol & \\
\hline $\begin{array}{l}\text { Diethylstilbestrol } \\
\text { (Stilbestrol) }\end{array}$ & & $\begin{array}{l}\text { Dietilestilbestrol } \\
\text { (DES) }\end{array}$ & $\begin{array}{l}\text { Dietilestilbestrol } \\
\text { (DES) }\end{array}$ & & & RF-00000289-VET & $\begin{array}{l}\text { Diethylstilbestrol } \\
\text { (Stilbestrol) }\end{array}$ & \\
\hline $\begin{array}{l}\text { Diethylstilbestrol } \\
\text { dipropionate } \\
\text { (Stilbestroldipropi } \\
\text { onate) } \\
\end{array}$ & & & & & & RF-00000290-VET & $\begin{array}{l}\text { Diethylstilbestrol } \\
\text { dipropionate } \\
\text { (Stilbestroldipropi } \\
\text { onate) }\end{array}$ & \\
\hline Fosfestrol & & & & & & RF-00000285-VET & Fosfestrol & \\
\hline Hexestrol & & Hexestrol (HEX) & Hexestrol (HEX) & & & RF-00000292-VET & Hexestrol & \\
\hline Mestilbol & & & & & & RF-00000287-VET & Mestilbol & \\
\hline & Tireostáticos & Tireostáticos & & & & RF-00000293-VET & Antithyroid agents & \\
\hline $\begin{array}{l}\text { 2- } \\
\text { Mercaptoimidazol } \\
\text { e }\end{array}$ & & $\begin{array}{l}\text { Mercaptobenzimid } \\
\text { azol (MBI) }\end{array}$ & $\begin{array}{l}\text { Mercaptobenzimid } \\
\text { azol (MBI) }\end{array}$ & & & RF-00000298-VET & $\begin{array}{l}\text { 2- } \\
\text { Mercaptoimidazol } \\
\text { e }\end{array}$ & \\
\hline $\begin{array}{l}\text { 5-Ethinyl-2- } \\
\text { thiouracil }\end{array}$ & & & & & & RF-00000304-VET & $\begin{array}{l}\text { 5-Ethinyl-2- } \\
\text { thiouracil }\end{array}$ & \\
\hline $\begin{array}{l}\text { 5-Methyl-2- } \\
\text { thiouracil }\end{array}$ & & & & & & RF-00000305-VET & $\begin{array}{l}\text { 5-Methyl-2- } \\
\text { thiouracil }\end{array}$ & \\
\hline $\begin{array}{l}\text { 5-Propyl-2- } \\
\text { thiouracil }\end{array}$ & & & & & & RF-00000301-VET & $\begin{array}{l}\text { 5-Propyl-2- } \\
\text { thiouracil }\end{array}$ & \\
\hline $\begin{array}{l}\text { 6-Methyl-2- } \\
\text { thiouracil }\end{array}$ & & $\begin{array}{l}\text { Metiltiouracilo } \\
\text { (MTU) }\end{array}$ & $\begin{array}{l}\text { Metiltiouracilo } \\
\text { (MTU) }\end{array}$ & & & RF-00000297-VET & $\begin{array}{l}\text { 6-Methyl-2- } \\
\text { thiouracil }\end{array}$ & \\
\hline $\begin{array}{l}\text { 6-Propyl-2- } \\
\text { thiouracil }\end{array}$ & & $\begin{array}{l}\text { 4(6)-n-propil-2- } \\
\text { tiouracilo (PTU) }\end{array}$ & $\begin{array}{l}\text { 4(6)-n-propil-2- } \\
\text { tiouracilo (PTU) }\end{array}$ & & & RF-00000303-VET & $\begin{array}{l}\text { 6-Propyl-2- } \\
\text { thiouracil }\end{array}$ & \\
\hline Benzylthiouracil & & & & & & RF-00000300-VET & Benzylthiouracil & \\
\hline
\end{tabular}

The present document has been produced and adopted by the bodies identified above as author(s). This task has been carried out exclusively by the author(s) in the context of a contract between the European Food Safety Authority and the author(s), awarded following a tender procedure. The present document is published complying with the transparency principle to which the Authority is subject. It may not be considered as an output adopted by the Authority. The European Food Safety Authority reserves its rights, view and position as regards the issues addressed and the conclusions reached in the present document, without prejudice to the rights of the author(s). 
Table 12: Controlled Terminology - Matrix from DGAV (Example)

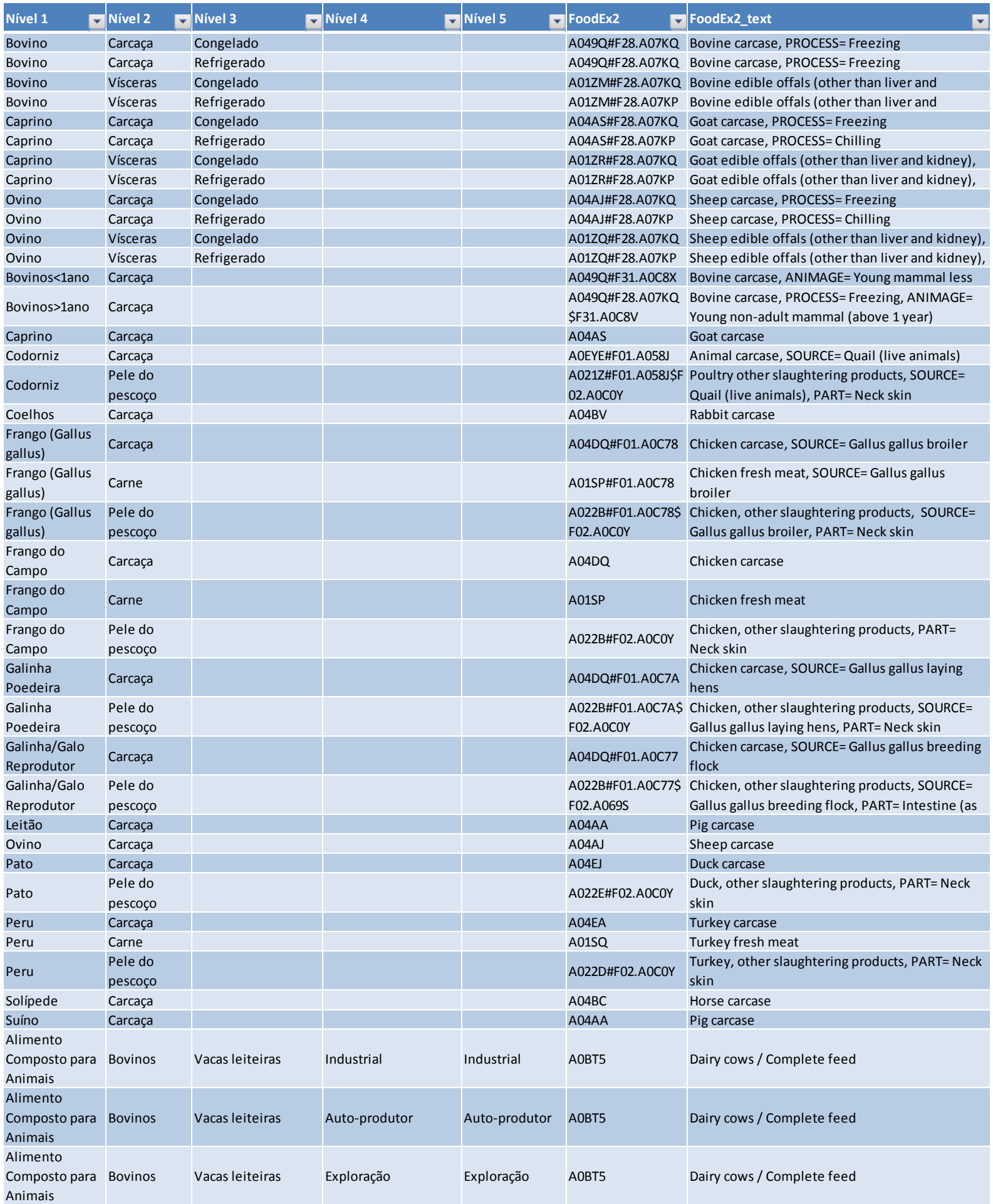

The present document has been produced and adopted by the bodies identified above as author(s). This task has been carried out exclusively by the author(s) in the context of a contract between the European Food Safety Authority and the author(s), awarded following a tender procedure. The present document is published complying with the transparency principle to which the Authority is subject. It may not be considered as an output adopted by the Authority. The European Food Safety Authority reserves its rights, view and position as regards the issues addressed and the conclusions reached in the present document, without prejudice to the rights of the author(s). 
Table 13: Controlled Terminology - NUTS from DGAV

\begin{tabular}{|ll}
\hline DAV & D.04 \\
\hline SDA Faial & PT2 \\
\hline SDA Flores & PT2 \\
\hline SDA Pico & PT2 \\
\hline SDA S. Jorge & PT2 \\
\hline SDA S. Miguel & PT2 \\
\hline SDA Santa Maria & PT2 \\
\hline SDA Terceira & PT2 \\
\hline DAV Alentejo Central & PT183 \\
\hline DAV Alentejo Litoral & PT181 \\
\hline DAV Alto Alentejo & PT182 \\
\hline DAV Baixo Alentejo & PT184 \\
\hline DAV Faro & PT15 \\
\hline DAV Aveiro & PT161 \\
\hline DAV Castelo Branco & PT169 \\
\hline DAV Coimbra & PT16 \\
\hline DAV Guarda & PT168 \\
\hline DAV Leiria & PT163 \\
\hline DAV Viseu & PT165 \\
\hline DAV Oeste & PT16B \\
\hline DAV Ribatejo & PT16C \\
\hline DAV Setúbal & PT172 \\
\hline DHPV & PT112 \\
\hline DAV Braga & PT118 \\
\hline DAV Bragança & PT115 \\
\hline DAV Chaves - Mirandela & PT114 \\
\hline DAV Porto & PT111 \\
\hline DAV Viana do Castelo & PT117 \\
\hline DAV Vila Real - Douro Sul & \\
\hline & \\
\hline
\end{tabular}


Table 14: Controlled Terminology - Sampling Point from DGAV

\begin{tabular}{|l|l|l|}
\hline Fases da cadeia & SSD2 & Coluna1 \\
\hline Produção & E300A & Manufacturing \\
\hline Produção primária & E100A & Primary production \\
\hline Produção/Indústria & E301A & Processing plant \\
\hline Distribuição & E500A & Distribution: wholesale and retail sale \\
\hline Retalho & E520A & Retail \\
\hline
\end{tabular}

Table 15: Controlled Terminology - Program type from DGAV

\begin{tabular}{|lll|}
\hline Fases da cadeia & SSD2 & Texto \\
\hline Autocontrolo & K012A & Industry/ private programme \\
\hline Inspeção Sanitária & K022A & Monitoring \\
\hline Abate sanitário & K021A & Control and eradication programmes \\
\hline Gripe Aviária & K021A & Control and eradication programmes \\
\hline RASFF & K033A & RASSF alert notification \\
\hline PIGA & K005A & Official (National) programme \\
\hline PIGA (Seguimento) & K026A & Surveillance \\
\hline PNCR & K005A & Official (National) programme \\
\hline PNCR (ASAE) & K005A & Official (National) programme \\
\hline PNCR (Suspeita/Sequestro) & K026A & Surveillance \\
\hline Pesticidas & K005A & Official (National) programme \\
\hline PVRAM & K005A & Official (National) programme \\
\hline Outro & K029A & Unspecified \\
\hline CAA & K005A & Official (National) programme \\
\hline Certificação para exportação & K019A & EU increased control programme on imported food \\
\hline & & \\
\hline
\end{tabular}

Table 16: Controlled Terminology - Units from INIAV

\begin{tabular}{|l|l|l|}
$\begin{array}{l}\text { Expressão } \\
\text { resultados } \\
\text { (unidades) }\end{array}$ & SSD2_Unidades & Text \\
\hline$\mu \mathrm{g} / \mathrm{kg}$ & G050A & Microgram/kilogram \\
\hline$\mu \mathrm{g} / \mathrm{l}$ & $\mathrm{G} 051 \mathrm{~A}$ & Microgram/litre \\
\hline $\mathrm{mg} / \mathrm{kg}$ & $\mathrm{G} 061 \mathrm{~A}$ & Milligram/kilogram \\
\hline $\mathrm{ug} / \mathrm{l}$ & $\mathrm{G} 051 \mathrm{~A}$ & Microgram/litre \\
\hline $\mathrm{mg} / \mathrm{l}$ & G062A & Milligram/litre \\
\hline $\mathrm{ug} / \mathrm{kg}$ & $\mathrm{G} 050 \mathrm{~A}$ & Microgram/kilogram \\
\hline
\end{tabular}


Table 17: Controlled Terminology - Methods from INIAV

\begin{tabular}{|c|c|c|}
\hline Método & SSD2_Método & SSD2_Método2 \\
\hline L.01 & L.04 & \\
\hline $\begin{array}{l}\text { PE-089-TSA/AR (08-04-2014) Pesquisa de resíduos de estilbenos - método de triagem e confirmação } \\
\text { por LC-MS/MS }\end{array}$ & F027A & LC-MS/MS \\
\hline $\begin{array}{l}\text { PE-106-TSA/AR (15-04-2014) Pesquisa de resíduos de esteroides e estilbenos - método de triagem e } \\
\text { confirmação por LC-MS/MS }\end{array}$ & F027A & LC-MS/MS \\
\hline $\begin{array}{l}\text { PE-088-TSA/AR (23-06-2014) Pesquisa de Resíduos de Tireóstaticos- método de triagem e } \\
\text { confirmação por LC-MS/MS }\end{array}$ & F027A & LC-MS/MS \\
\hline $\begin{array}{l}\text { PE-092-HP/BR (05-05-2014) Pesquisa de resíduos de Lactonas do Ácido Resorcílico - método de } \\
\text { triagem e confirmação por GC-MS }\end{array}$ & F046A & GC-MS \\
\hline $\begin{array}{l}\text { PE-096-TSA/AR (15-04-2014) Pesquisa de resíduos de AINE's - método de triagem e confirmação por } \\
\text { LC-MS/MS }\end{array}$ & F027A & LC-MS/MS \\
\hline $\begin{array}{l}\text { PE-108-TSA/AR (15-04-2014) Pesquisa de resíduos de anti-inflamatórios não esteroides - Método de } \\
\text { triagem e confirmação por LC-MS/MS }\end{array}$ & F027A & LC-MS/MS \\
\hline $\begin{array}{l}\text { PE-021-TSA/AR (23-06-2014) Pesquisa de resíduos de corticosteroides -método de triagem e } \\
\text { confirmação por LC-MS/MS }\end{array}$ & F027A & LC-MS/MS \\
\hline $\begin{array}{l}\text { PE-037-TSA/AR (23-06-2014) Pesquisa de resíduos de metabolitos de nitrofuranos- método de } \\
\text { triagem e confirmação por LC-MS/MS }\end{array}$ & F027A & LC-MS/MS \\
\hline $\begin{array}{l}\text { PE-050-TSA/AR (23-06-2014) Pesquisa de resíduos de nitroimidazóis - método de triagem e de } \\
\text { confirmação LC-MS/MS }\end{array}$ & F027A & LC-MS/MS \\
\hline $\begin{array}{l}\text { PE-066-TSA/AR (22-04-2014) Pesquisa de resíduos de coccidiostáticos - método de triagem e } \\
\text { confirmação por LC-MS/MS }\end{array}$ & F027A & LC-MS/MS \\
\hline $\begin{array}{l}\text { PE-109-TSA/AR (07-04-2015) Pesquisa de resíduos de coccidiostáticos - Método de triagem e } \\
\text { confirmação por LC-MS/MS }\end{array}$ & F027A & LC-MS/MS \\
\hline $\begin{array}{l}\text { PE-084-TSA/AR (07-04-2015) Pesquisa de resíduos de avermectinas -método de triagem e } \\
\text { confirmação por HPLC-FL }\end{array}$ & F022A & HPLC-FD \\
\hline $\begin{array}{l}\text { PE-107-TSA/AR (07-04-2015) Pesquisa de resíduos de anti-helmintícos - método de triagem e } \\
\text { confirmação por LC-MS/MS }\end{array}$ & F027A & LC-MS/MS \\
\hline $\begin{array}{l}\text { PE-097-TSA/AR (06-07-2015) Pesquisa de resíduos de agonistas beta-adrenérgicos -método de } \\
\text { triagem e confirmação por LC-MS/MS }\end{array}$ & F027A & LC-MS/MS \\
\hline $\begin{array}{l}\text { PE-098-TSA/AR (11-04-2014) Pesquisa de residuos de agonistas beta-adrenérgicos -metodo de } \\
\text { triagem e confirmação por LC-MS/MS }\end{array}$ & F027A & LC-MS/MS \\
\hline PE-041-TSA/AR (23-06-2014) Doseamento de cádmio e chumbo por Z-ETA-AAS & F054A & ETAAS (GFAAS) \\
\hline PE-006-TSA/AR (16-06-2014). Doseamento de cádmio e chumbo por Z-ETA-AAS & F054A & ETAAS (GFAAS) \\
\hline $\begin{array}{l}\text { PE-045-TSA/RT (2013-07-09). Pesquisa de resíduos de pesticidas organoclorados - Método de } \\
\text { Triagem por GC-MS }\end{array}$ & F046A & GC-MS \\
\hline $\begin{array}{l}\text { PE-064-TSA/RT (2013-07-09) Pesquisa de resíduos de pesticidas organoclorados - Método de } \\
\text { confirmação por GC-MS }\end{array}$ & F046A & GC-MS \\
\hline PE-063-HP/RT-P (2012-07-31). Pesquisa de resíduos de piretróides - Método de triagem por GC-ECD & F039A & GC-ECD \\
\hline $\begin{array}{l}\text { PE-044-TSA/RT. Pesquisa de resíduos de cloranfenicol em leite. Método de triagem por ELISA (Ed.05 } \\
\text { de 02/06/2014) }\end{array}$ & F080A & $\begin{array}{l}\text { Enzyme-linked immunosorbent assay } \\
\text { (ELISA) }\end{array}$ \\
\hline PE-043-TSA/RT (2014-06-02) Determinação de Cloranfenicol. Método de triagem por ELISA & F080A & $\begin{array}{l}\text { Enzyme-linked immunosorbent assay } \\
\text { (ELISA) }\end{array}$ \\
\hline PE-002-TSA/CAA Ed.4(15-5-2015) - Pesquisa de agonistas beta-adrenérgicos por ELISA & F080A & $\begin{array}{l}\text { Enzyme-linked immunosorbent assay } \\
\text { (ELISA) }\end{array}$ \\
\hline PE-107-HP/CAA - Pesquisa de nitrofuranos - Método de triagem por HPLC-DAD & F587A & HPLC-DAD \\
\hline $\begin{array}{l}\text { PE-116-HP/CAAPesquisa de resíduos de agonistas beta-adrenérgicos - Método de triagem e } \\
\text { confirmação por LC-MS/MS }\end{array}$ & F027A & LC-MS/MS \\
\hline PE-118-HP/CAA Pesquisa de Ractopamina - Método de Triagem por ELISA & F080A & $\begin{array}{l}\text { Enzyme-linked immunosorbent assay } \\
\text { (ELISA) }\end{array}$ \\
\hline PE-118-HP/CAA Pesquisa de Ractopamina - Método de Triagem por ELISA (alimento) & F080A & $\begin{array}{l}\text { Enzyme-linked immunosorbent assay } \\
\text { (ELISA) }\end{array}$ \\
\hline
\end{tabular}

The present document has been produced and adopted by the bodies identified above as author(s). This task has been carried out exclusively by the author(s) in the context of a contract between the European Food Safety Authority and the author(s), awarded following a tender procedure. The present document is published complying with the transparency principle to which the Authority is subject. It may not be considered as an output adopted by the Authority. The European Food Safety Authority reserves its rights, view and position as regards the issues addressed and the conclusions reached in the present document, without prejudice to the rights of the author(s). 
In order to maximize the future automation of the data collecting system, mapping tables (already submitted to EFSA with the Document D1 - Data Standardization: the encoding and mapping strategy developed and used) between the controlled vocabularies used in the entities mentioned above and the controlled vocabularies used in the SSD2 system were made. These mapping tables will be included in the software developed, and DGAV will be responsible for their maintenance. This will allow the country to continue using and updating the terminologies employed on each data source and matches those to the EFSA controlled terminology values.

\subsection{Data collection, collation and mapping to SSD2}

For the sampling period to which the project relates (2015), information on more than 30000 analytical determinations was collected.

The information available in each data sources extracted directly from their electronic systems was not sufficient to complete all the mandatory fields requested by EFSA or to be mapped directly to EFSA's SSD2; therefore, it was necessary to request additional information and to perform several transformations to the original data. The extension of the transformations and missing information varied according to the data source.

In annex A we show all the specific transformation made in the VMPR data domain, to accomplish all EFSA requested information, necessary to fulfill SSD2 fields.

The linkage between "sample collection files" and "results files" was made using the IT tool described in chapter 3.6. After the linkage a human readable EXEL file in SSD2 format was produced and validated by the data domain experts, considering coherence and specific business rules. Subsequently, data was coded to SSD2 catalogues and the XML was produced to be transmitted through DCF.

\subsection{IT tool to manage sample and results filles for the XML fille production}

As it was referred in the sub-section 2.3.2 Software Tools of the 'Methods and Materials' section, some tools were developed in order to help the technicians, that report the data, meet the deadline and to avoid the manual operations and transformation (raw information to SSD2 language and codes) that were to be executed in case of such tools did not exist. Also referred in the Software Tools subsection, the developed software had to be created in a short time; as such an agile methodology of development took place having only as main requirements the basic modules to produce a XML file based on the Excel files received from several sources.

This tool was developed specifically for this data transmition; it was only a small portion of the main module that is being developed for the PT.ON.DATA platform. Just to reinstate what was mentioned previously, the tool was only developed in the same amount of time available since the main SSD2 solution for Portugal was still in development and not ready to be use. 


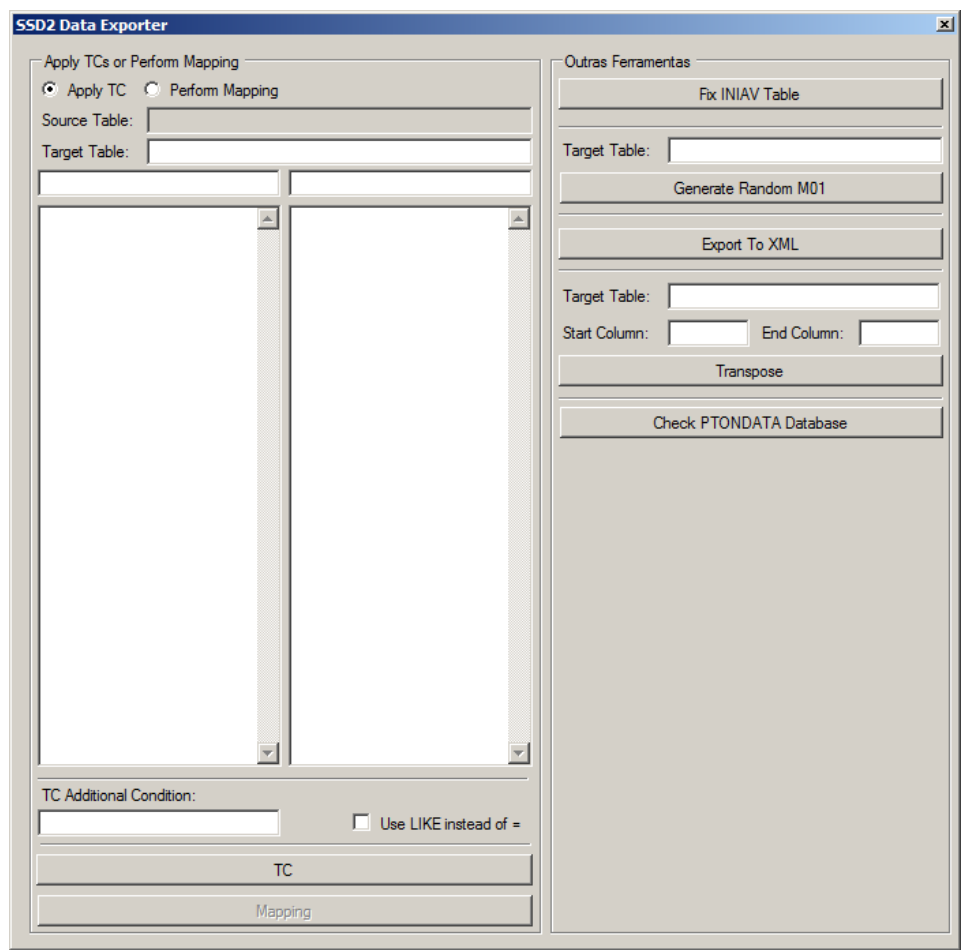

Figure 2: $\quad$ Software developed for the data report (Main Screen)

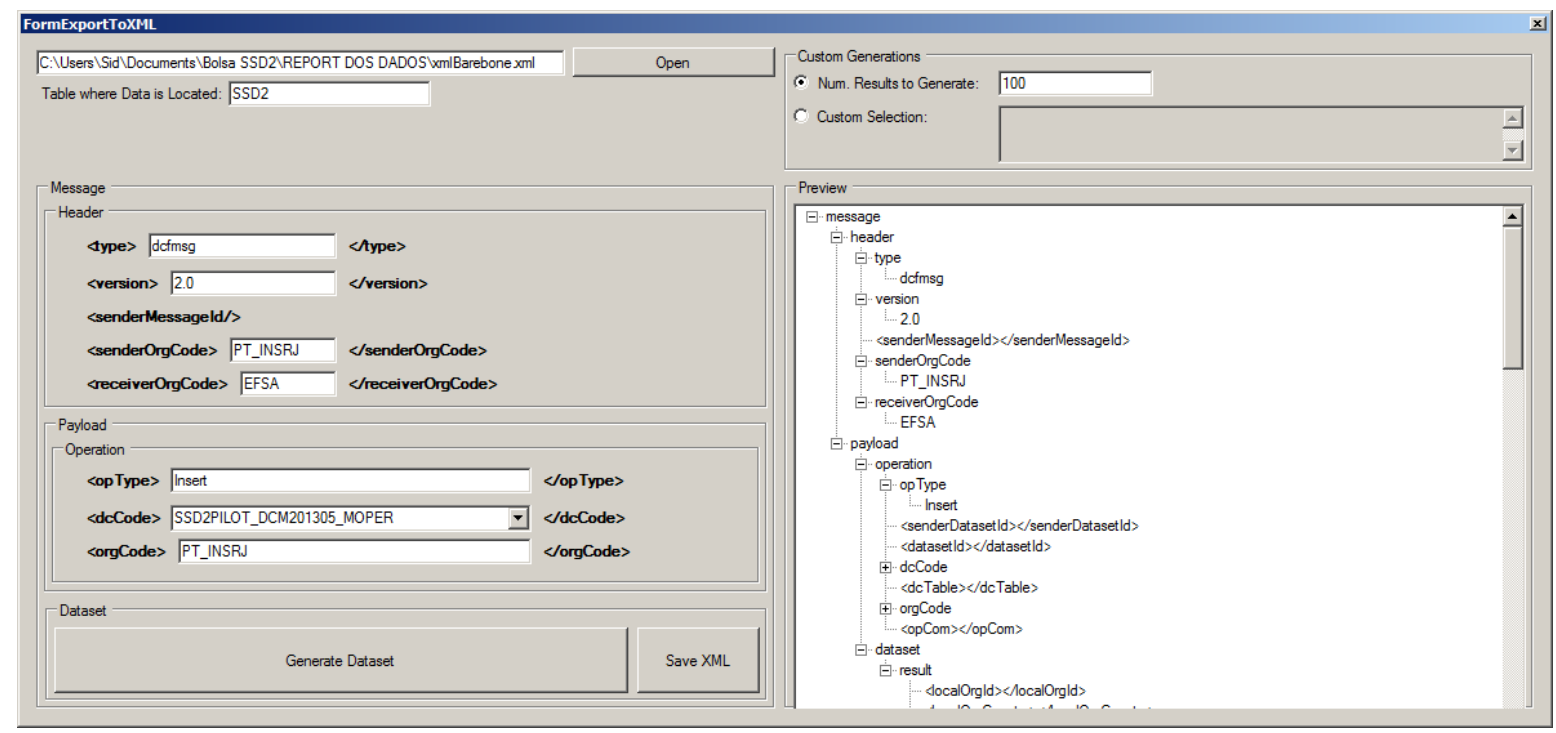

Figure 3: $\quad$ Software developed for the data report (Export XML screen)

The SSD2 Data Export tool shown in the picture 2 and 3 has implemented multiple functionalities that were suggested to be created by the team technicians once they realized that most data did not followed a common layout and structure for the data to be manipulated before the SSD2 transformations could take place. As such, functionalities like table transposition, specific checks on the information in order to identify missing data, data mapping, and employment of Translation Tables (TC in Portuguese), are present in this tool. 


\subsection{PT.ON.DATA2}

The national database, PT.ON.DATA for SSD1, is in development, their modules and functionalities will be upgraded in order to extend to all the domains now covered by the new version of the standard (SSD2). This new process of expanding the existing system is a huge and delicate task which involves other tools developed since the start of the project. Despite PT.ON.DATA 1 for SSD1 only covered the Chemical Contaminants and the Food Additives domain we think that as an advantage to use and improve existing functionalities that where common in both versions of the standard (Data Upload, Data Mapping, Business Rules check, Data Transformation to XML) and expand the existing project rather than start a new database project.

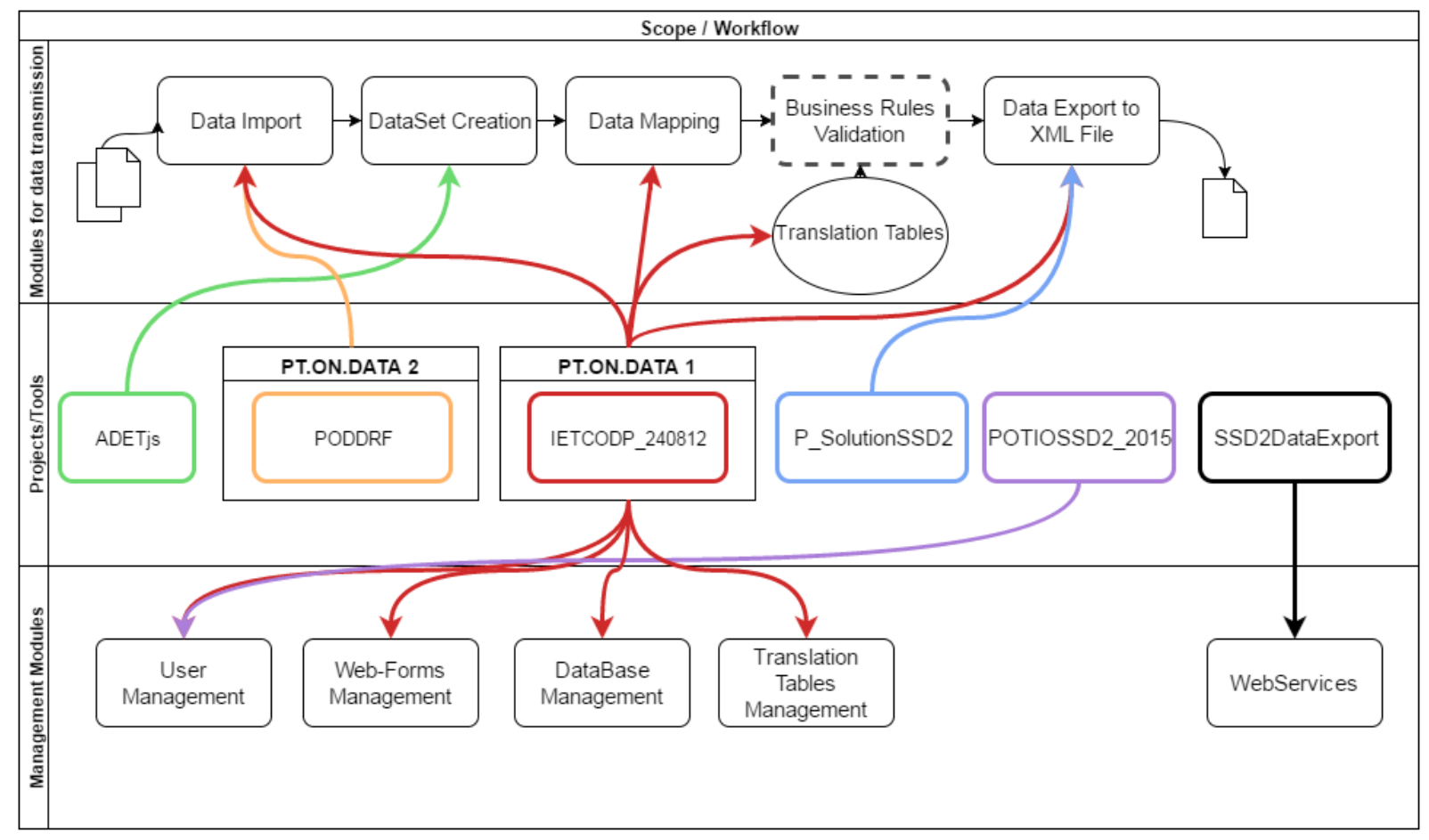

Figure 4: Top level diagram displaying developed tools to date in and how are being reused to develop PT.ON.DATA 2

The diagram above (figure 4) shows all the developed tools and projects that will help expand the PT.ON.DATA 1 platform to the SSD2. All modules in the first row of the diagram are still being implemented, the others that not make part of the first project are being planned and designed to be created by the ITs.

\subsection{Web services}

Already described in the 2.3.3 section, the task of testing the Web Services functionalities took place in the early stages of development of the new PT.ON.DATA platform; as such the several modules that composed the whole platform did not exist at the time, so they couldn't communicate with each other, i.e., for example there wasn't a Data Export module that would extract the information from the database and send it to the Web Service Communication Module to report that data to EFSA. This resulted in the creation of additional tools that helped testing these specific functions that were crucial 
in the early stages to know with some certainty if they were or not to be included in the final platform. In the figure 4 , it is possible to visualize the overall workflow of the new PT.ON.DATA platform on the top section of the diagram, displaying the several modules, and since the Web Services were yet to be properly analysed, a tool named "SSD2DataExport", shown in the Project/Tools section at the very end of the diagram, was developed using the same development environment as the platform, which is under the .NET Framework using the CSharp language, however this tool would be a Desktop Windows Form application, differing from the web platform using ASP.NET technologies.

The SSD2DataExport tool was a very rudimentary application however at the time of its development it turned out to be quite useful once the required data submission to test the SSD v. 2 were nearby and we had to have the updated catalogues.

Aside from testing some Web services (WS) methods and successfully retrieving, this tool also helped identifying some problems related to a few WS methods that were functioning incorrectly or not functioning at all. These problems will be discussed later in this report.

After some months developing the new platform and each of its main modules, we decided to initiate the implementation the WS Communication Module, using what we had learned from the SSD2DataExport tool. Since this module had to be included in the web platform, it could no longer be a desktop form application, however taking in consideration that the environment itself was the same (Microsoft's .NET), we had no problem adapting the existing code. As the WS Communication Module is still on its very early stage of development, where it has its core functionalities implemented and are enough to complete the tasks described in the Tender Specification, it has many aspects were it should be improved.

Both groups of WS methods for catalogue retrieval and data transmission are implemented inside the same WS Communication Module, but they are presented as different tools when requested by a platform user.

In relation to the data submission task and the data used to be transmitted over the Web Services, a simple dataset was prepared based on a previous report made to EFSA. This dataset was cut down in order to facilitate the transmission and make somewhat easy to debug in case a problem occurred, less data is easier to analyse and treat compared to a large dataset. The figure below, Base dataset used for data submission, shows the dataset created with only two results which hidden in the figure but have some data in them that is not relevant to show.

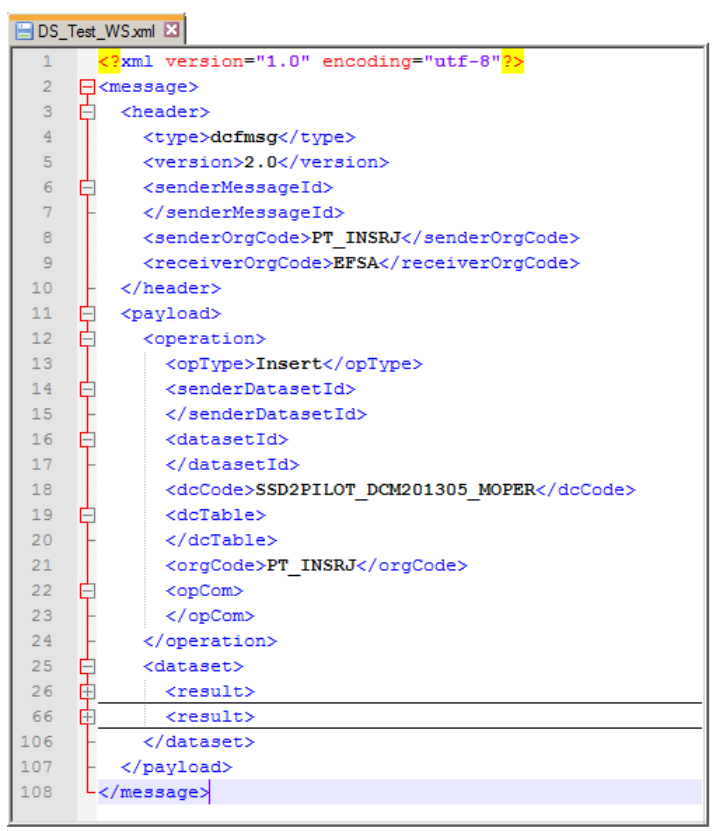

Figure 5: Base dataset used for data submission 
It is important to note that the file DS_Test_WS.xml shown in the figure 5 is the base dataset used to test the transmission, i.e., multiple files were used on the test and suffered slight modifications in order to comply with all the dataset operations (Insert, Replace, Partial-Replace, Partial-Delete, Delete, Submit, Reject and Confirm).

Also related to the test of the data transmission, we made use of a very important free tool named SoapUI (figure 6). We advise to use it since it is very helpful to analyse the raw message that sent and is also received from EFSA's side. In our opinion it is easier tweak some communication settings, ex: security configurations, and read soap messages than using some IDE internal debugger.

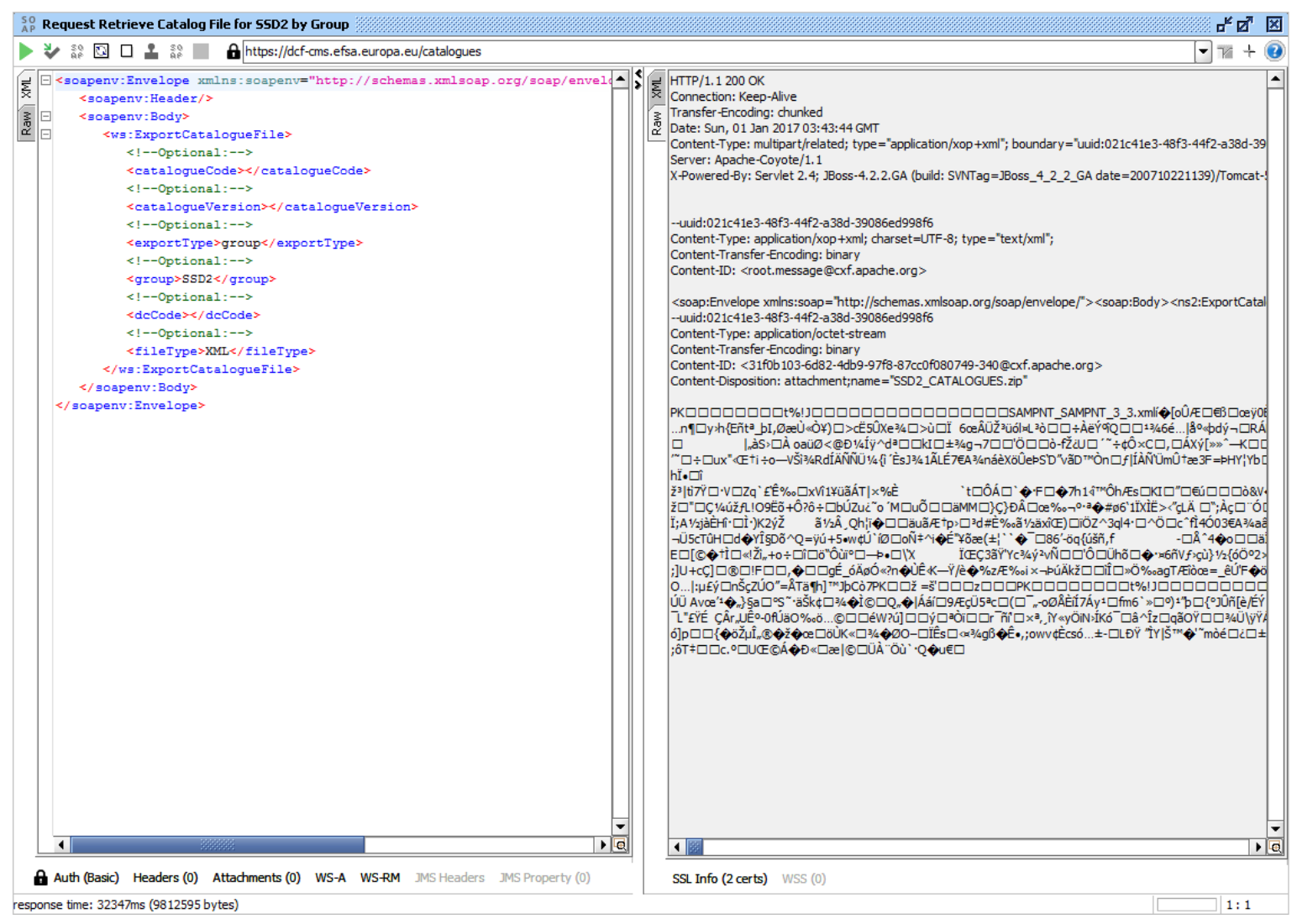

Figure 6: SoapUI interface for data analysis

Moving to the subject of data used related to the catalogues retrieval test, there are two databases used by the PT.ON.DATA platform. The first database it's supposed to be static, since it is accessed by the ORM (Object-relational mapping) solution named Entity Framework developed by Microsoft, and for this type of ORM tables can't be created nor have their structure modified once the software is in production. As such, this first database only contains table that remain the same throughout the entire and expected lifetime of the platform. This resulted in the creation of a second database which would contain catalogues related information since one the main objectives of our platform was to allow the possibility to add, remove and edit any catalogue in the system, whether it is a catalogues by EFSA or by a national organisation. This database, differing from the previous one, isn't accessible by the ORM solution, which meant that some sort of interface had to be developed in order to access the several catalogues and their related information as objects, as we wanted to avoid manipulating SQL statements directly. Fortunately this interface was developed in time for the tasks of testing the Web Services for catalogues retrieval which meant that the WS Communication Module could use this interface to read and update the catalogues.

The catalogues database was then created with all the catalogues that were made available by EFSA through the publication of the GDE 2 article where it had the Excel files attached to it. It is important 
to note that never a catalogue has been imported to the database in the XML format now chosen and requested by the appropriate WS. The figure below shows the basic structure of the catalogue database.

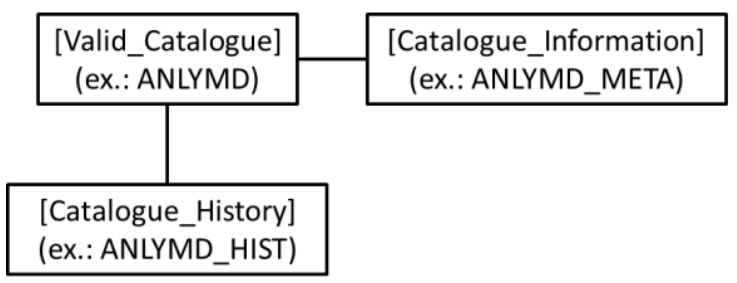

Figure 7: $\quad$ Catalogues Database basic structure (example for the ANLY catalogue)

As shown in the figure 7 , each catalogue consists of basically three different tables. The first table identified in the figure by VALID_CATALOGUE represents the full and ready to be used catalogue, it has all usable terms and they are all up to date. This table, however, doesn't have the information related to the terms, this table only consists of unique keys which references the term itself that is stored the second table shown, the CATALOGUE_HISTORY table. This second table has all the terms that ever existed for that catalogue, all the different versions, whether they are up to date or deprecated. Finally we have the CATALOGUE_INFORMATION table which contains metadata related to the catalogue, for example, it has the current version of the catalogue, the last time it was updated, its name, code, etc.

This solution for the catalogues database was chosen since all data that were imported into our system had to be accessible at time with the same information as it had when it got in. A history had to be maintained in order to access the original data whether a term of the catalogue previously referenced had now been updated.

For both data transmission and catalogue retrieval tasks the actual mean of communication had to be developed in order to communicate via Web Services. Since EFSA implemented and described on their side Web Services using the SOAP protocol specification and since we were already using a Microsoft environment for our development, we had the required tools to start communicating. The IDE that we were using in conjunction with the .NET technology also being used allowed for a simple import of the WS definition into our solution. An option is available in the IDE (Service References) which, through the WSDL link provided in the GDE 2 and the DCF manual, auto-generates the required class that represents the objects being sent between the two endpoints, and also generates the configurations required for the communication to start. However only the classes' generation part of this process truly worked since the generated configurations were completely incorrect, but this subject will be discussed in the next sub-section.

After having the bottom layer required to start communicating with EFSA, which includes the autogenerated objects and the additional code developed, we only needed now to provide a user interface. 


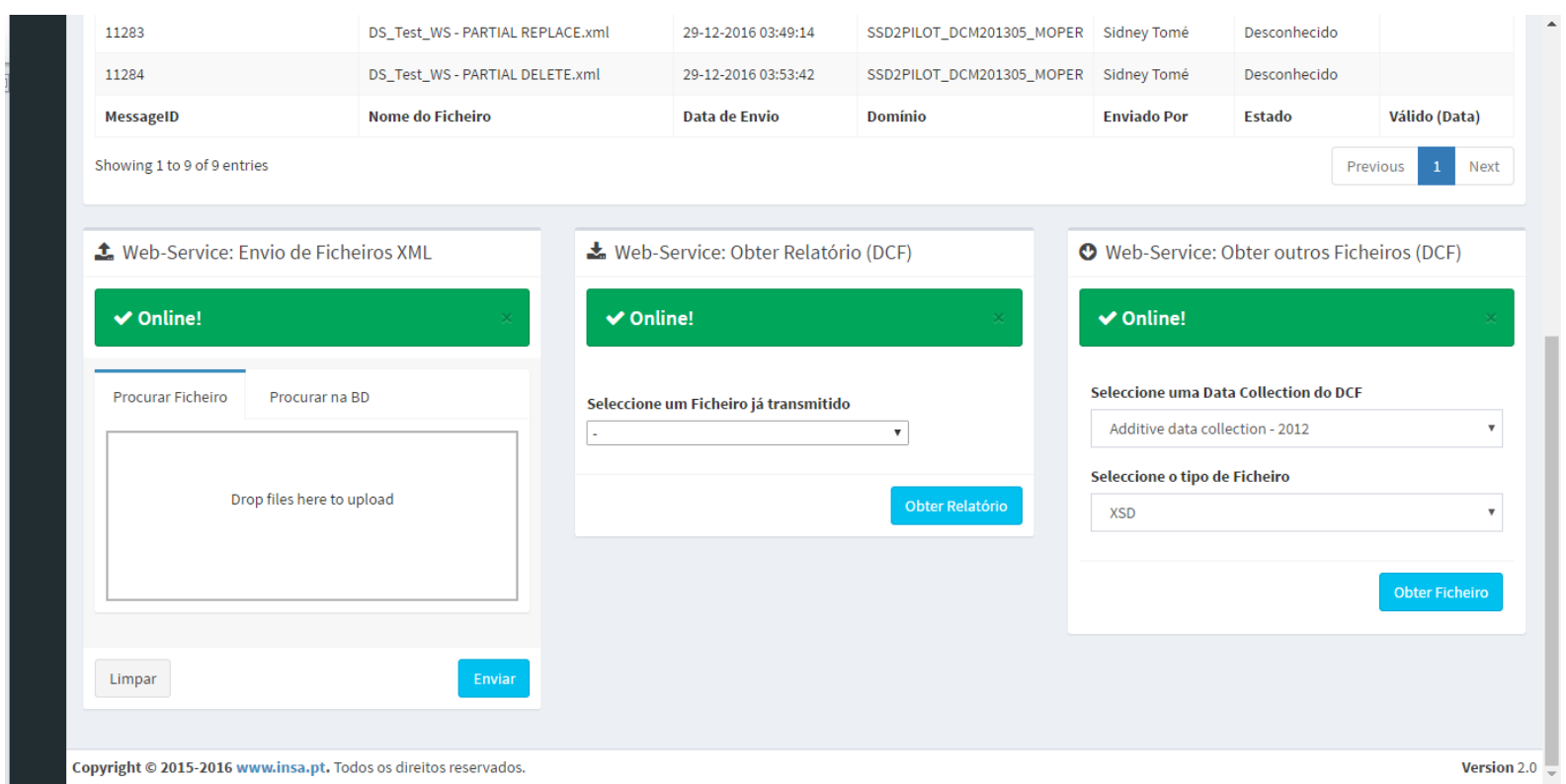

Figure 8: $\quad$ Data Transmission UI for the PT.ON.DATA 2 platform

The figure 8 shows the User Interface created and integrated with the web platform PT.ON.DATA 2. Through this UI it is possible to identify multiples web services methods that were being used at the same time in a completely transparent way for the user.

The green containers displayed in the figure with the text "Online!" represent the response receive after calling the Ping method of the dcf-elect.efsa.europa.eu/elect2 web service. This container has the purpose of letting the user know that he can successfully start using the available WS functionalities.

The left-most container that has the title "Web-Service: Envio de Ficheiros XML" contains the main operations that achieves the tasks of data transmission. In this container the user has an option of being able to drag and drop any XML file with report data. Once the target file has been dropped in the container, the user only has to press the blue button "Enviar" for the SendMessage() WS method to be called. After the call successfully been made, the user will receive a message display that information, and at the same time the database used by the PT.ON.DATA platform will have a table dedicated for XML transmissions populated with the MessageID received after the SendMessage() call.

The stored MessageID can now be utilized by the user to track down the status of the file reported via WS. The figure below, shows the functionality made available for the user through the option shown in the second/middle container that has the title "Web-Service: Obter Relatório (DCF)". In this container the user only has to choose from a list of already sent XML report files, which file he wants to know the status of. 


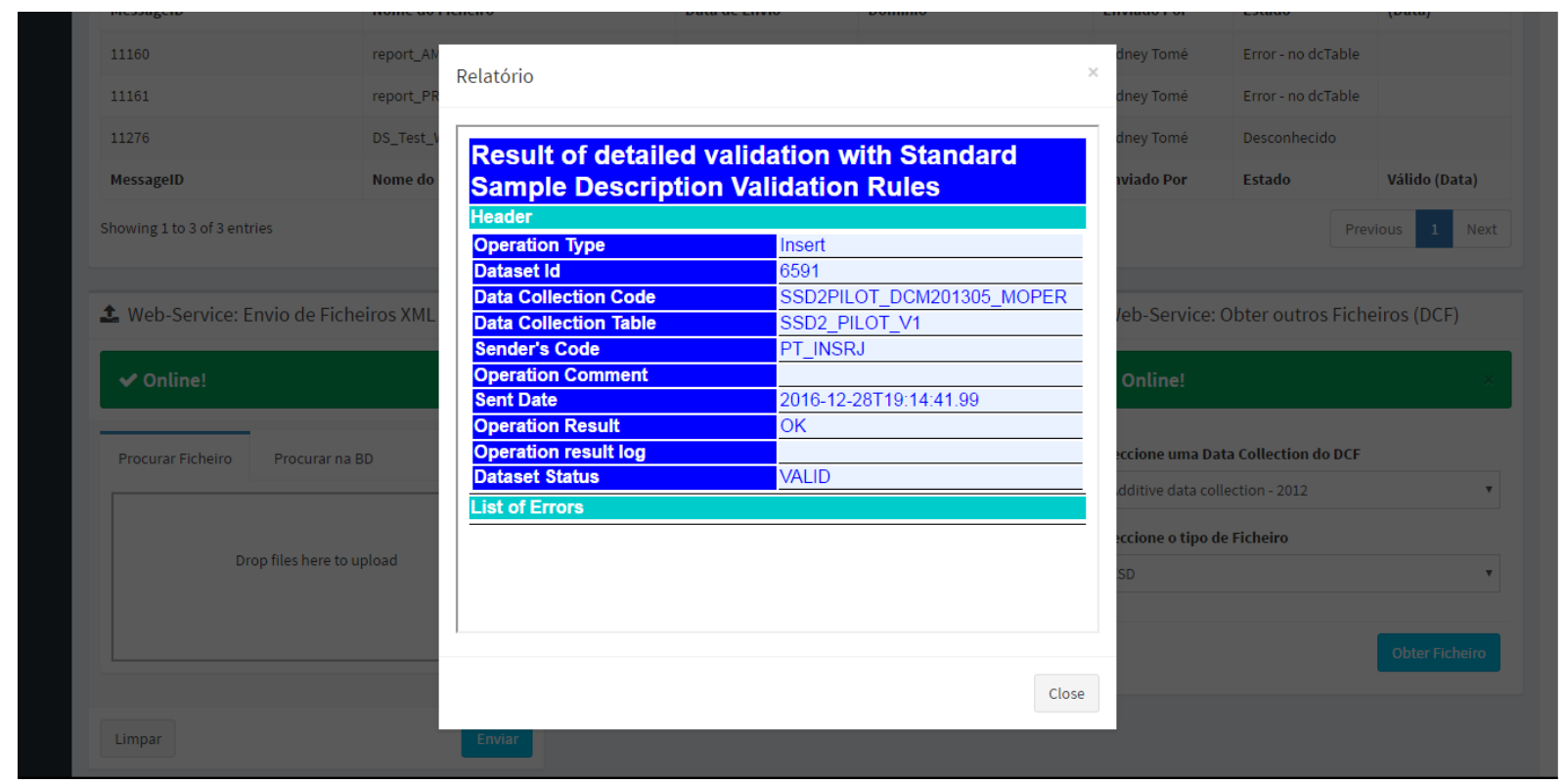

Figure 9: Visualization of the reported file status in the PT.ON.DATA platform

The retrieval of a report status is done through the call of the GetFile() WS method sending as parameters the DATAILED_ACK_RES_ID option number (i.e. "06_") and the MessageID selected previously by the user from the list. The visual display of the information received in binary form as a response of the GetFile() call was made through the help of the FormatGDESchema.xslt file made available by EFSA, and since this results on a HTML string, we had no problem in integrating it on our web platform.

As it was mentioned in a previous section of this report, many XML report files were sent in order to test the many existing dataset operations, this can be seen in the table shown at the top. All possible operations were tested successfully and their status helped confirming this result.

Finally in the right-most container we give the user the possibility of being able to download any resource file available in the DCF, through the use the GetDataCollectionList(), GetResourceList() and also the GetFile(), all represent by the lists in this container with the title Web-Service: Obter outros Ficheiros (DCF).

As for the catalogue retrieval task that had to be accomplished, another user interface was created and made available for the user, the figure below displays the resulting UI. 


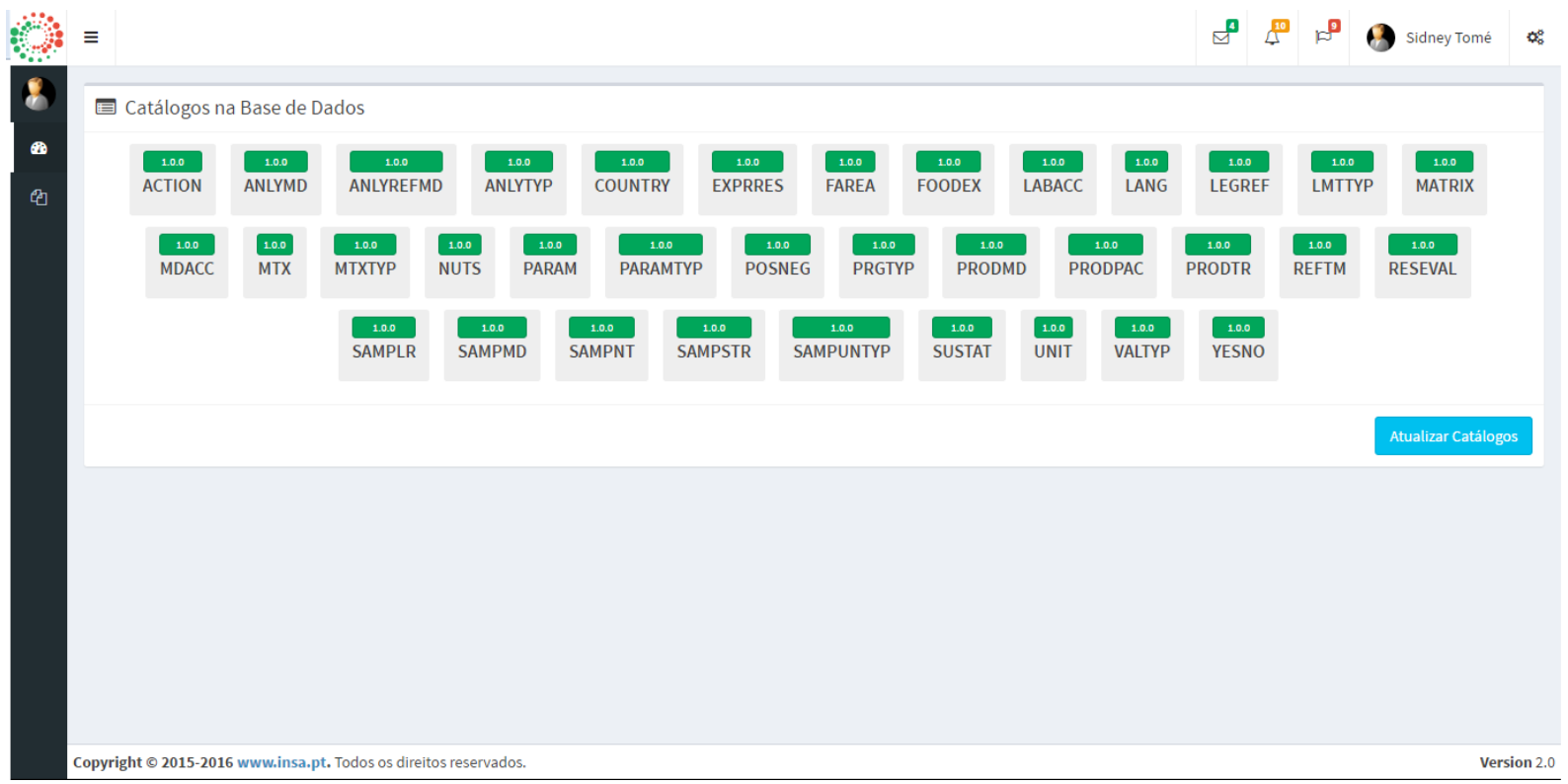

Figure 10: $\quad$ Updating of catalogues UI for the PT.ON.DATA 2 platform

As a result of manually inserting into the system for the first the catalogues made available in Excel format when the GDE 2 and SSD 2 were published, each catalogue version was manually inserted with the version "1.0.0". This turned out to be quite helpful now testing the catalogues retrieval web services methods since it aided ensuring that all catalogues were to be updated.

The interface shown in the figure 10 is very simple and has a very direct purpose; with a press of a button (the blue button with the "Atualizar Catalogos" label) the user is able to check with the DCF platform for any catalogue that needs to be updated. This interface makes use of the ExportCatalogueFile() method made available on dcf-cms.efsa.europa.eu/catalogues endpoint. This method has a very simple used signature: ExportCatalogueFile(String.Empty, String.Empty, "group", "SSD2", String.Empty, "XML"); which its simplicity helps achieving exactly what is needed, all SSD v.2 catalogues, since we are reporting in this format, and in XML files.

The resulting Zip file after calling the ExportCatalogueFile() is read and decompressed in memory, and every file extracted this way, still in memory, is read in order to compare versions. Each XML representing a catalogue has the catalogue version read and compared with the catalogue version stored the PT.ON.DATA second database ([CATALOGUE_INFORMATION] table, (Figure 7). In case the XML file has the higher version, an process of update takes place, where each term in the XML file has its version compared with the term version in the [VALID_CATALOGUE] table (Figure 7), if the term in the XML file has a higher version then this term added to the [CATALOGUE_HISTORY] table (Figure 7) and the reference to this term is updated in the [VALID_CATALOGUE] table. In case a term is not found in the [VALID_CATALOGUE] table, a search is performed on the [CATALOGUE_HISTORY] table, if it happens to not exists in this table, the term is added to the history table and its reference to the valid catalogue table.

Once all terms have its version compared, the [CATALOGUE_INFORMATION] table will have the according metadata information updated, finalizing the catalogues retrieval and update task. 


\subsection{Describe issues encountered (details)}

The main issue encountered when implementing the Web Services communication was related to the classes/objects auto-generated and required configurations when telling the IDE (Visual Studio) that we wanted to add Services References.

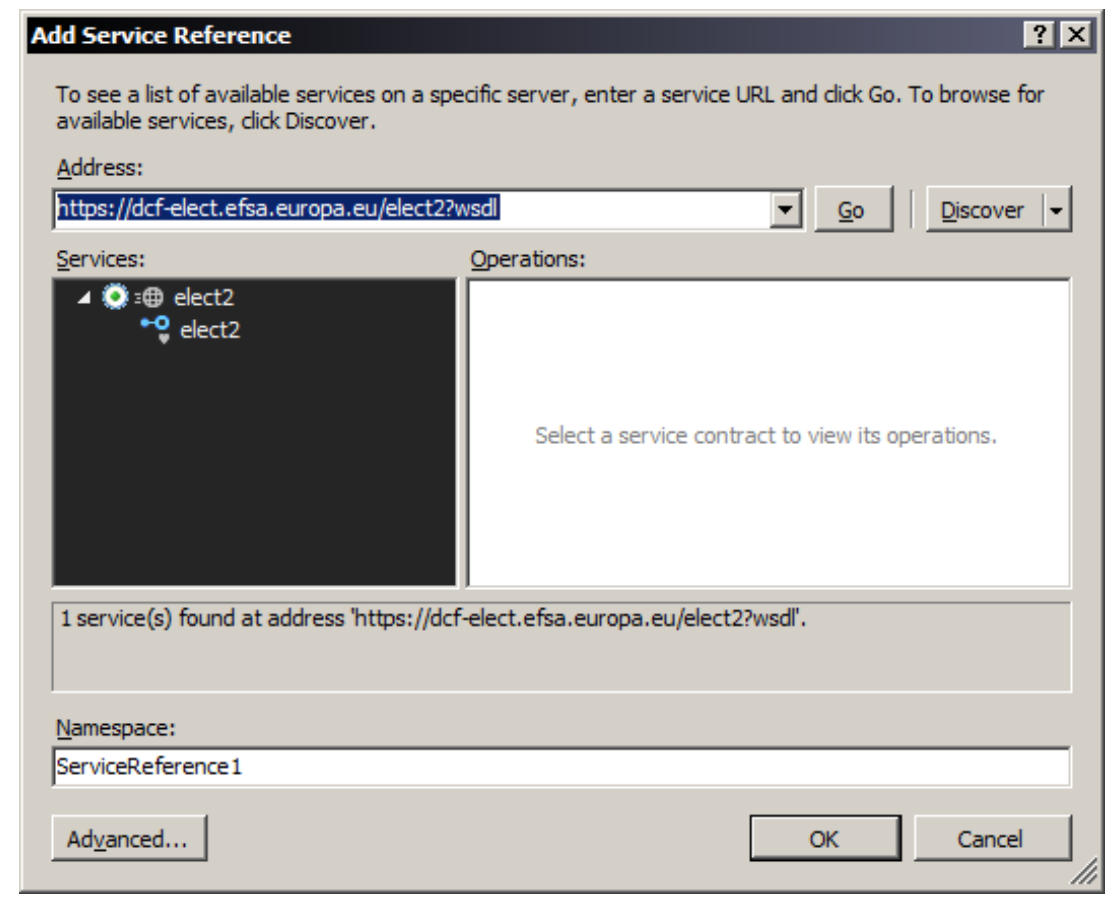

Figure 11: $\quad$ Add Service Reference Wizard (Visual Studio)

After using the wizard shown in Figure 11, a set of abstract classes are automatically generated which represent the client object and objects that will be transmitted in the messages between the two endpoints. These classes are generated correctly, as expected to since it all circles around the Microsoft domain. However the issue arises when automatically generating the configurations that should be used by the client object.

The generated configurations are supposed to be created based on the WSDL read from the link, but seeing the result of this generation process, the configurations are completely incorrect. The resulting configuration states that the communication should be performed under the HTTP Transport protocol instead of the HTTPS Transport, no authentication methods are said to be used when clearly it is needed a Basic type of authentication (Username and Password), and finally it also incorrectly states that the type of SOAP messages being traded is a Text type of message, when it should of MTOM type (Message Transmission Optimization Mechanism) since not only text is sent in the SOAP messages but also binary information is sent, in attachments for example.

We believe that problem relies in the WSDL definition on EFSAs side, but we are not sure. We were able to successfully communicate with other SOAP type of Web Services, yet fail when trying to do the same through the automated process. Also in the process of trying to solve this problem, we've found out that this is a common issue when a .NET oriented application tries to communicate with a Java oriented application via Web Services.

We were able to solve this problem by specifying through code the correct configurations, but the most important piece that had to be created in order to have the communication working was a custom message encoder. Although specifying, ultimately forcing by code, that we wanted to use the 
existing implementation of a MTOM message encoder available in the .NET libraries, we were unable to receive SOAP messages and decode them. An exception was always being thrown stating that the SOAP message was malformed when coming from EFSAs side.

In order to solve this first and considered to be a more serious issue, we had to implement from scratch a somewhat low level custom message encoder (named internally DCFMessageEncoder). This custom encoder is a variation of the MTOM encoder but allowed us to treat the incoming message however we wanted. The incoming messages were received in binary format, and we decided to analyse this binary content as to identify the problem. We weren't able to exactly pinpoint the error with the message but it seemed that extra characters (binary values) were being sent in the SOAP message header resulting in the message malformation exception. We solved this problem by unpacking the received message and reconstructing it resulting in a new, properly formed, SOAP message that was being able to be read from now on.

The second and less serious issue that we encountered was related with the error messages received in the messages as a response by EFSAs side. Whenever we incorrectly used a method signature, some of the times we would receive a message point the exact error that we committed when calling a method, and that message was helpful finding the problem and solving it. An example of this is when we forgot to state the dcTable value in the dcTable element in the XML report file, and the response would say exactly that, to name a dcTable related to the data being. However there was message sent as a response to improper use of a WS method that would only have in the body of the message the word "FAIL", leaving us unable to know exactly where we failed, resulting in a process of trial and error in order to found the problem.

\subsection{Improvement proposals and recommendations}

In this subsection, we will present our feedback and concerns in relation to some elements, which are listed below, that were found to be of most importance to point them out in order to improve the SSD2 standard and all the involved data treatment and reporting processes. Some of these topics that will be discussed were also identified in previous reports for other domains, however due to our experience on treating and transmitting SSD2 data, most of those problems were simply bypassed by creating internal procedures to deal with them, or their existence were acknowledged and we proceeded to create temporary solutions. Since we are noticing some reoccurrence of these same issues, now for this domain and its transmission, we've decided to identify them in an exact manner and propose some resolutions.

\subsubsection{Reporting guidelines}

Before pointing out the issues with the main documents that guideline the VMPR data transmission, we've felt that another problem should be addressed first, since it was considered to be the one which caused most discord when analyzing and treating the data. We're referring to the fact that most of these same documents can be found in multiples repositories, however this wouldn't be a problem if they all had the same version, preferably the most recent one, or at least the repositories should have the different versions for download. Most of the time what happened is that we would have some member of the data treatment team that received, directly from EFSA via e-mail, the required documents (Reporting Guidelines and other equally important files), however the rest of the team members that also require these documents to work on the data would acquire such files from EFSA's website (as an example), since they didn't receive the e-mail -and- the information was also available somewhere else, what it was believed to be the same information. This would result on some confusion when the two parts of the team encountered problems related to the data. A considerable amount of time and resources had to be diverted in order to solve this versioning problem, but we 
think it could be easily avoided if these repositories would not have these files themselves but instead have a reference link to a main repository (preferably related to the DCF) where all versions would exist.

Finally, the second main issue that we've found, now related to the reporting guidelines themselves, could be describe in a very succinct manner. The Reporting Guidelines should always present examples whenever applicable. It is true that the documents present some examples, and even when it makes since to have examples when referring to some domain specific case, for instance. However we felt that more examples are needed; from our experience on submitting data to EFSA, most problems occur with non-expected cases, that weren't either expected to occur by us the data provider, or by the data receiver, since it wasn't mentioned in the guidelines. Whether it is a simple field in the SSD2 that wasn't properly filled in, or business rule that wasn't properly respected, we think that there should always be present an example (or pair of examples) on how should a field or BR should be respected in order to have the Valid output, and what kind of inputs would cause the different cases of Invalid outputs, causing the data to be rejected.

\subsubsection{SSD2 Data Model for VMPR}

As for the SSD2 Data Model currently in use for the VMPR domain, we have some doubts about the necessity of the member states provide information that is not important from the EFSA point of view. Some of these fields are really important but only to the reporting countries self control, for us is not information relevant for the EFSA risk assessment.

One of the fields that is mandatory in SSD2 Data Model and in our opinion should be optional is the C 05 - Other sampling unit identifications (e.g.: animal identification code; flock/herd code; batch code), sharing this information may cause some problems with regard to transparency issue and FBO data confidentiality, the same for the M.04 and M.05 fields that shouldn't be always mandatory since there are some methods that is not possible to calculate LOQ only LOD should be required. The M.08 and M.09 have the same problem in certain methods it should be sufficient to refer only the CC alpha value, because like the previous case some methods don't have CC beta value.

Other issue that should be reviewed is the discrepancies between the data model for VMPR and the DCF business rules, in several cases fields which are optional in the VMPR Guidelines are mandatory in DCF structure, this brings extra work to solve this problems (as C.01 and F.01 - classified as optional, however causes an error on report, needs to be filled in).

Another case that we would like to draw attention to is the field N.04 (Evaluation of the result). Not always the evaluation of the result is based only on a test result, there are situations in which a sample may be above a certain legal limit and not considered positive, there may be other factors to take into account that lead us to consider the sample negative. The sample final evaluation can be influenced by several conjugated results. This situation may lead to the existence of false positives.

Going beyond these "small" details we think that in a general way the data model adopted for VMPR fits very well to the needs of the domain.

\subsubsection{SSD2 catalogues}

As for the actual use of the catalogues provided for the VMPR report, we also noted some confusion when cleaning and preparing the data. Before talking in more detail about the content of the catalogues themselves, we would like to raise again the already mentioned problem related to the versioning of multiples file, we found to be a really big problem when we discover that part of the team has been using the wrong codes in the process of data mapping to SSD2, only to have it all redone later. Since we've already talked about these issues, there is no need to go more into it, however we would like to suggest some workarounds to avoid this type of dilemma. We think that some kind of changelog should exist for most documents, but especially for the catalogue files. It is 
very important to know what kind of changes took place from the previous versions, and this information should be placed in a single place, whether is on a specific portion of file dedicated only to this information, or on an official document produced by EFSA. Equally relevant to point out in relation to this topic, this changelog should include a description or some type of reference to the description that depicts the reasons behind the changes. It is critical to show the interpretation/reasoning behind the adjustment so the data provider team has a sense, not only of choosing the correct option for the data, but also an understanding of the path that the SSD2 standard is taking.

A second aspect that we would like to mention is related to the structure in which most catalogues are presented. We've felt that most catalogues that are set up in a tree format (such as the PARAM) should have some tools that would allow a more efficient and precise search. Not only tree structured catalogues should have such type of assistance, other catalogues that also depend of other attributes besides the SSD2 Code. A possible solution would be to make available a tool similar to the FoodEx Browsing Tool, which brings the desired ability to retrieve the correct code in an efficient manner. This possible tool could be applied to any catalogue in the SSD2 model, and instead of being a standalone software, it could be integrated with the DCF, since the platform somewhat possesses a browsing functionality.

\subsubsection{VMPR requirements and the related Business Rules}

Related to the requirements presented and the assigned business rules to the VMPR domain, we only have a few points to raise to question. We've noticed in this transmission and in previous ones for others domains that the received business rules that we, data providers, found out that they weren't the same as the business rules that were being applied in the DCF. We think that it would be preferred to have the data providers refer to the DCF and have the current business rules, the ones that are actually applied to the data, retrieved from there, instead of having others repositories for this purpose.

Speaking specifically to the content of the business rules, we've only determined that some of them could be followed with a better, or a more extended, description. We would also suggest to have more examples that would cause de business rules to fail and examples that would lead to a valid result after applying the BR.

\section{Conclusions}

There are some technical issues for us to complete our mapping to the SSD2. Some of them are outlined in the bullet points below:

- The organizations involved in the official controls have their own databases and only some of the fields are populated with controlled vocabulary, the most difficult was to collect all the controlled terminologies and do the mapping to the SSD2 terms.

- The dispersion of data made the annual reporting to EFSA a highly laborious process.

- Sometimes it was necessary to overcome some administrative barriers to obtain the necessary data.

- We identified some fields with no controlled vocabularies so we received a large amount of data that had to be subjected to technical screening and its subsequent correspondence to the SSD2 system.

- The coding of samples according to FoodEx2 is the most time consuming task and a solution to make the process automated keeping adequate sample information detail was not found yet. It would be important to invest in this field in a near future. 
- The matrix catalogue based on FoodEx2 available in the catalogue file of the Guidelines for reporting data on residues of veterinary medicinal products is outdated. Some codes attributed to food matrices gave an error in file submission in the DCF.

- The fact that DCF only identifies a specific number of errors in each run makes the submission and validation process very time consuming.

- EFSA should provide a pre-validation tool with all DCF business rules in order to permit that each country can pre-validate their own data before the DCF data submission. This tool would probably reduce the time consuming for the validation process in DCF.

- The delay on the implementation of the web services on the DCF platform hindered the implementation of D3 and D4. It also led to a great deal of IT's time consumption in solving various communication problems detected during the implementation of Web services.

- When implementing the Web Service Communication module, the development process occurred properly as it was expected. The only recommendations that we think that should be given is, perhaps, to present more documentation with the types of responses expected for each WS method and describing them in more detail, specially the error messages and error codes used (if any).

- It might help to implement the communication interfaces and solve problems related to them if some documentation is created in relation to the technologies, software, tools, protocols, and other elements used by EFSA when creating the Web Service access on their side.

There are several specific issues that have to be overcome to the implementation of the SSD2 model in the VMPR Data Domain in Portugal.

The biggest problem to be solved is to improve the data quality in order to facilitate their treatment, all technicians involved in the process should be aware of the importance of quality of data collected.

Since it will cannot be possible to implement the same controlled languages in all institutions that carry out the official control plans it will be important that the existing languages can be reviewed and standardized, if created new terms they should approach to the EFSA terms.

In our opinion the implementation of SSD2 in the VMPR will be easy since it was already experimented in Chemical Contaminants, Food Additives and Pesticides Residues domains and it was compatible with the level of information requested. 


\section{References}

- EFSA (European Food Safety Authority), 2015. Guidelines for reporting data on residues of veterinary medicinal products. EFSA supporting publication 2015:EN-783. $77 \mathrm{pp}$.

- European Food Safety Authority, 2014. Guidance on Data Exchange version 2.0. EFSA Journal 2014;12(12):3945, 173 pp., doi:10.2903/j.efsa.2014.3945

- European Food Safety Authority; Standard sample description for food and feed. EFSA Journal 2010;8(1):1457 [54 pp.]. doi:10.2903/j.efsa.2010.1457. Available online: www.efsa.europa.eu

- GUIDANCE OF EFSA - Standard Sample Description ver. 2.0 - EFSA Journal 2013;11(10):3424. http://www.efsa.europa.eu/en/efsajournal/pub/3424.htm

- GUIDANCE OF EFSA - Standard Sample Description ver. 2.0 - EFSA Journal 2013;11(10):3424. EXCEL Supplementary Material Table. http://www.efsa.europa.eu/en/efsajournal/pub/3424.htm

- National controlled terminologies and data formats 


\title{
Glossary [and/or] Abbreviations
}

\author{
CA Autoridade Competente/ Competent Authority \\ CAA Controlo da Alimentação Animal/ Animal Feed Control \\ DGAV Direção Geral Alimentar e Veterinária/ General Directorate of Food and Veterinary \\ Affairs \\ INIAV Instituto Nacional de Investigação Agrária e Veterinária/ National Agrarian and \\ INSA Veterinary Research Institute \\ INSA Instituto Nacional de Saúde Dr. Ricardo Jorge/ The National Health Institute Doutor \\ Ricardo Jorge \\ PNPR Plano Nacional de Pesquisa de Resíduos/ National Residue Monitorin Plan \\ NAUTILUS Sistema Informático Laboratorial/ Laboratory Information System \\ SIPACE Sistema de Informação do Plano de Aprovação e Controlo dos Estabelecimentos/ \\ Informatic System to support the Approval and Establishments Control Plan
}




\section{Annex A - Changes made in the entities data files for the $\mathbf{2 0 1 5}$ data transmission of residues of veterinary medicinal products (VMPR).}

\section{Previous Note}

The original files have not been changed. Copies were created, and all changes made were to those copies. 


\section{Content}

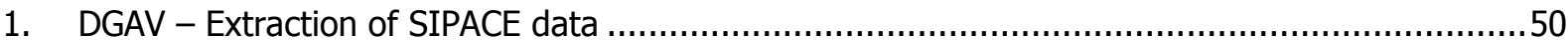

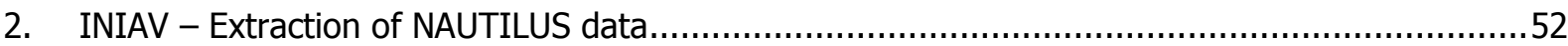

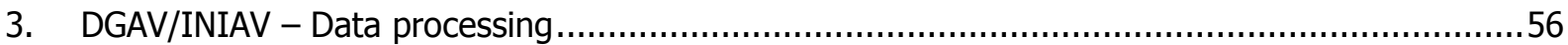

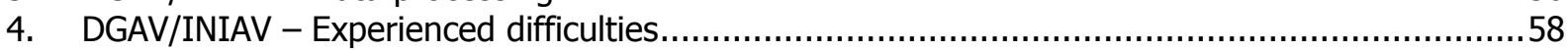

The present document has been produced and adopted by the bodies identified above as author(s). This task has been carried out exclusively by the author(s) in the context of a contract between the European Food Safety Authority and the author(s), awarded following a tender procedure. The present document is published complying with the transparency principle to which the Authority is subject. It may not be considered as an output adopted by the Authority. The European Food Safety Authority reserves its rights, view and position as regards the issues addressed and the conclusions reached in the present document, without prejudice to the rights of the author(s). 


\section{List of Figures}

Figure 1 - Data received from SIPACE (partial view) ..................................................... 51

Figure 2 - File with VMPR "Parametro" only (partial view) ............................................. 52

Figure 3 - Column "CodigoAmostra" - Example of codes to be corrected (partial view) .................5 52

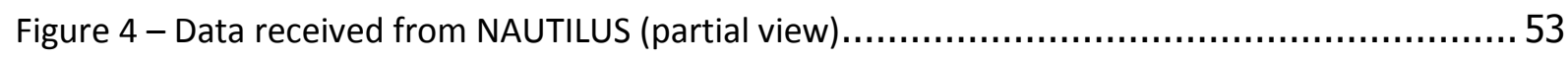

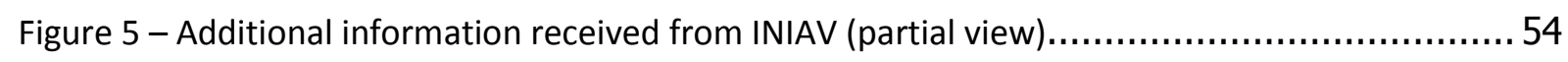

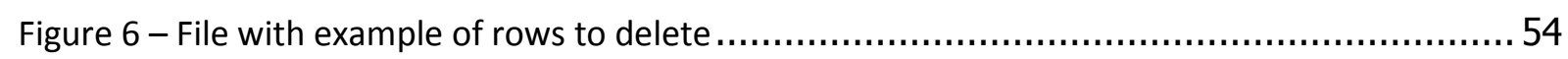

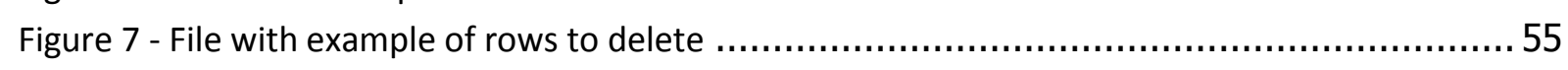

Figure 8 - File with indication of the column to be separated (partial view) ............................. 55

Figure 9 - Detail concerning the separation of the column "external_reference". Original column on the left and separate column on the right "Referencia" (partial view) .................................... 56

Figure 10 - Detail of the columns for which the two files are connected. On the left the results file

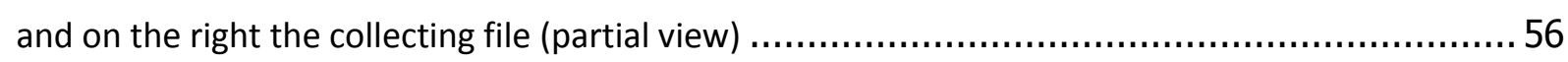

Figure 11 - Detail relative to the result column "formatted_result" (partial view) ........................ 59 


\section{DGAV - Extraction of SIPACE data}

Data was extracted from the SIPACE database in Excel format (figure 1). From this file the following fields must be extracted in order to ensure the information necessary to meet EFSA requirements.

- ID SIPACE

- DAV

- DataColheita

- CodigoAmostra

- NumeroSeloAmostra

- Parametro

- TipoExploracao

- ExploracaoPais

- Ambito
- $\quad$ TipoProdutoNivel1

- TipoProdutoNivel2

- FaseCadeia

- Laboratorio

- DataResultado

- NumBoletimLaboratorio

- Resultado

- Quantificacao

- AmostraPrejudicadPor

\section{Note}

Data extraction should be done as closely as possible to the date of transmission in order to ensure that all data available for the report is properly entered into the system (SIPACE). 


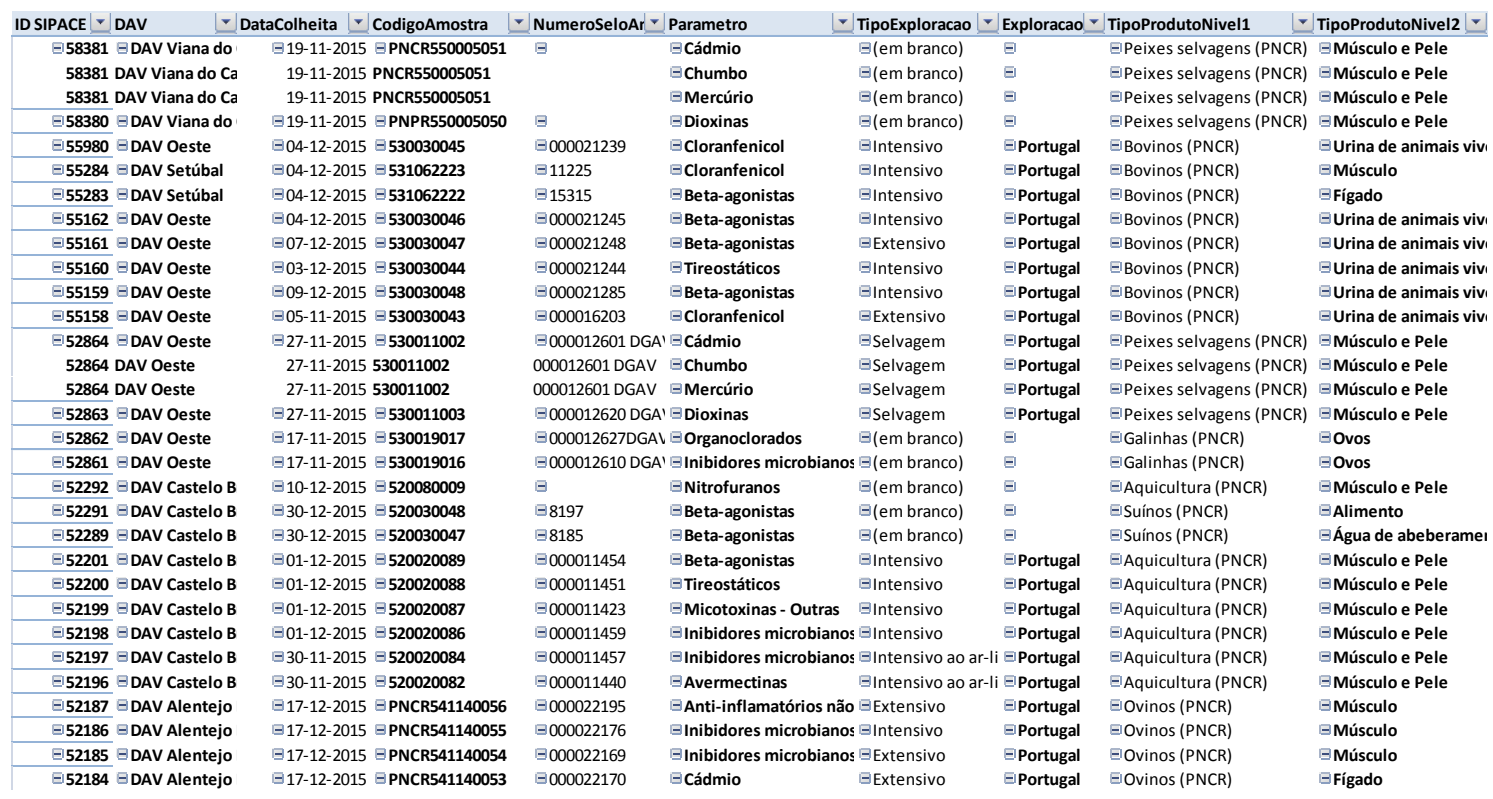

Figure 1 - Data received from SIPACE (partial view)

\section{of Procedure\#1}

DGAV - Residues of veterinary medicinal products

Data relating to the Animal Feed Control (CAA) plan that were not entered into the system were added to the SIPACE data file. This operation was performed manually since there were few data, thus making it possible to maintain the SIPACE headers.

\section{o3 Procedure\#2}

DGAV - Residues of veterinary medicinal products

In the "Parametro" column filter / select all the analyzes that are not related to the residue of veterinary medicinal products (VMPR) domain and delete them, leaving only the lines corresponding to the domain that we are treating, as exemplified in Figure 2.

The present document has been produced and adopted by the bodies identified above as author(s). This task has been carried out exclusively by the author(s) in the context of a contract between the European Food Safety Authority and the author(s), awarded following a tender procedure. The present document is published complying with the transparency principle to which the Authority is subject. It may not be considered as an output adopted by the Authority. The European Food Safety Authority reserves its rights, view and position as regards the issues addressed and the conclusions reached in the present document, without prejudice to the rights of the author(s). 


\begin{tabular}{|c|c|c|c|c|c|c|c|c|c|c|c|}
\hline ID SIPACE & DAV & DataColheita & CodigoAmostra & Numeros & lo Parametro & DExplorac & ExploracaoPais & TipoProduton TipoProdutoN & NFaseCadeia & Laboratc & riDataResultado NumBoletimLa \\
\hline 55980 & DAV Oeste & 04-12-2015 & ; 530030045 & 000021239 & Cloranfenico In & nsivo & Portugal & Bovinos (PNC Urina de anin & n Produção & INIAV & (em branco) \\
\hline 55284 & DAV Setúba & 04-12-2015 & 531062223 & 11225 & Cloranfenico In & nsivo & Portugal & Bovinos (PNC Músculo & Produção & INIAV & (em branco) \\
\hline 55283 & DAV Setúba & 04-12-2015 & 531062222 & 15315 & Beta-agonist Int & nsivo & Portugal & Bovinos (PNC Figado & Produção & INIAV & (em branco) \\
\hline 55162 & DAV Oeste & 04-12-2015 & 530030046 & 000021245 & Beta-agonist Int & nsivo & Portugal & Bovinos (PNC Urina de anin & n Produção & INIAV & (em branco) \\
\hline 55161 & DAV Oeste & 07-12-2015 & 530030047 & $00002124 \varepsilon$ & Beta-agonist $\mathrm{Ex}$ & ensivo & Portugal & Bovinos (PNC Urina de anin & n Produção & INIAV & (em branco) \\
\hline 55160 & DAV Oeste & 03-12-2015 & 530030044 & 000021244 & Tireostáticos $\ln$ & nsivo & Portugal & Bovinos (PNC Urina de anin & n Produção & INIAV & 29-03-2016 HP-15-03997/B| \\
\hline 55159 & DAV Oeste & 09-12-2015 & 530030048 & 000021285 & Beta-agonist In & nsivo & Portugal & Bovinos (PNC Urina de anin & n Produção & INIAV & (em branco) \\
\hline 55158 & 3 DAV Oeste & 05-11-2015 & 530030043 & "00001620 & Cloranfenico $\mathrm{Ex}$ & ensivo & Portugal & Bovinos (PNC Urina de anim & nProdução & INIAV & (em branco) \\
\hline 52862 & DAV Oeste & $17-11-2015$ & 530019017 & $00001262 \pi$ & COrganoclorar(e & branco) & & Galinhas (PNCOvos & Produção pri & i LGC & (em branco) \\
\hline 52861 & DAV Oeste & $17-11-2015$ & 530019016 & 000012610 & Inibidores $\mathrm{m}$ (e & (branco) & & Galinhas (PNCOvos & Produção pri & i LGC & (em branco) \\
\hline 52292 & DAV Castelc & $10-12-2015$ & 520080009 & & Nitrofuranos $(\mathrm{e}$ & (branco) & & Aquicultura (f Músculo e Pe & I Produção & INIAV & 10-05-2016 HP-16-00100/BI \\
\hline 52291 & DAV Castelc & 30-12-2015 & 520030048 & 8197 & Beta-agonist (e & branco) & & Suinos (PNCR'Alimento & Produção & INIAV & 31-03-2016 HP-16-00168/Q \\
\hline 52289 & DAV Castelc & 30-12-2015 & 520030047 & 8185 & Beta-agonist (e & branco) & & Suínos (PNCR Água de abeb & Produção & INIAV & 21-03-2016 HP-16-00170/Q \\
\hline 52201 & DAV Castelc & 01-12-2015 & 520020089 & 000011454 & Beta-agonist In & nsivo & Portugal & Aquicultura (f Músculo e Pe & I Produção pr & i LGC & (em branco) \\
\hline 52200 & DAV Castelc & c $01-12-2015$ & 520020088 & 000011451 & Tireostáticos $\ln$ & nsivo & Portugal & Aquicultura (f Músculo e Pe & I Produção pr & i LGC & (em branco) \\
\hline 52198 & 3 DAV Castelc & 01-12-2015 & 520020086 & 000011455 & Inibidores $\mathrm{m}$ & nsivo & Portugal & Aquicultura (f Músculo e Pe & IProdução pri & iLGC & (em branco) \\
\hline 52197 & DAV Castelc & 30-11-2015 & 520020084 & 00001145 & Inibidores $\mathrm{m}$ I & nsivo ao & Portugal & Aquicultura (f Músculo e Pe & I Produção pri & iLGC & (em branco) \\
\hline 52196 & DAV Castelc & 30-11-2015 & 520020082 & 00001144 & Avermectina In & nsivo ao & Portugal & Aquicultura (f Músculo e Pe & I Produção pri & iLGC & (em branco) \\
\hline 52187 & DAV Alentej & 17-12-2015 & PNCR541140056 & 000022195 & Anti-inflama Ex & ensivo & Portugal & Ovinos (PNCR Músculo & Produção & INIAV & (em branco) \\
\hline 52186 & DAV Alente] & 17-12-2015 & PNCR541140055 & "00002217 & Inibidores $\mathrm{m}$ In & nsivo & Portugal & Ovinos (PNCR Músculo & Produção & INIAV & (em branco) \\
\hline 52185 & DAV Alentej & 17-12-2015 & PNCR541140054 & 00002 & Inibidores $\mathrm{m}$ Ex & ensivo & Portugal & Ovinos (PNCRMúsculo & Produção & INIAV & inco) \\
\hline
\end{tabular}

Figure 2 - File with VMPR "Parametro" only (partial view)

\section{b) Procedure\#3}

DGAV - Residues of veterinary medicinal products

In the "CodigoAmostra" column delete all non-numeric characters and spaces and verify that all column data is formatted to numeric value (Figure 2).

\begin{tabular}{|c|c|c|c|c|c|c|c|c|c|c|c|}
\hline ID SIPACE & DAV & DataColheit= & CodigoAmostra & NumeroSelo & Parametro & TipoExplorac & c ExploracaoPais & TipoProduton TipoProdutoN & N FaseCadeia & Laboratc & riDataResultado NumBoletimLa \\
\hline 55980 & DAV Oeste & $04-12-20$ & 530030045 & 000021239 & Cloranfenico & oIntensivo & Portugal & Bovinos (PNC Urina de anim & n Producão & INIAV & (em branco) \\
\hline 55284 & DAV Setúba & $04-12-20$ & 531062223 & 11225 & Cloranfenico & o Intensivo & Portugal & Bovinos (PNC Músculo & Produção & INIAV & (em branco) \\
\hline 55283 & 3 DAV Setúba & 04-12-20: & 531062222 & 15315 & Beta-agonist & t Intensivo & Portugal & Bovinos (PNC Figado & Produção & INIAV & (em branco) \\
\hline 55162 & 2 DAV Oeste & 04-12-20: & 530030046 & 000021245 & Beta-agonist & t Intensivo & Portugal & Bovinos (PNC Urina de anim & n Produção & INIAV & (em branco) \\
\hline 55161 & DAV Oeste & $07-12-20$ & 530030047 & 000021248 & Beta-agonist & t Extensivo & Portugal & Bovinos (PNC Urina de anim & n Produção & INIAV & (em branco) \\
\hline 55160 & DAV Oeste & $03-12-20$ & 530030044 & 000021244 & Tireostáticos & sIntensivo & Portugal & Bovinos (PNC Urina de anim & n Produção & INIAV & 29-03-2016 HP-15-03997/B \\
\hline 55159 & DAV Oeste & $09-12-20$ & 530030048 & 000021285 & Beta-agonist & t Intensivo & Portugal & Bovinos (PNC Urina de anim & n Produção & INIAV & (em branco) \\
\hline 55158 & 3 DAV Oeste & $05-11-20$ & 530030043 & 000016203 & Cloranfenico & oxtensivo & Portugal & Bovinos (PNC Urina de anim & n Produção & INIAV & (em branco) \\
\hline 52862 & 2 DAV Oeste & $17-11-20$ & 530019017 & $000012627 \mathrm{DC}$ & Corganoclorar & (em branco) & & Galinhas (PNC Ovos & Produção pr & i LGC & (em branco) \\
\hline 52861 & I DAV Oeste & $17-11-20$ & 530019016 & $000012610 \mathrm{D}$ & Inibidores $\mathrm{m}$ & n (em branco) & & Galinhas (PNCOvos & Produção pri & i LGC & (em branco) \\
\hline 52292 & 2 DAV Castelc & $10-12-20$ & 520080009 & & Nitrofuranos & $\mathrm{s}$ (em branco) & & Aquicultura (₹Músculo e Pel & I Produção & INIAV & $10-05-2016$ HP-16-00100/B \\
\hline 52291 & 1 DAV Castelc & $30-12-20$ & 520030048 & 8197 & Beta-agonist & $t$ (em branco) & & Suinos (PNCR'Alimento & Produção & INIAV & 31-03-2016 HP-16-00168/Q \\
\hline 52289 & DAV Castelc & $30-12-20$ & 520030047 & 8185 & Beta-agonist & $t$ (em branco) & & Suinos (PNCR'Água de abebr & Produção & INIAV & 21-03-2016 HP-16-00170/Q \\
\hline 52201 & 1 DAV Castelc & $01-12-20$ & 520020089 & 000011454 & Beta-agonist & t Intensivo & Portugal & Aquicultura (F Músculo e Pel & IProdução pr & i LGC & (em branco) \\
\hline 52200 & DAV Castelc & $01-12-20$ & 520020088 & 000011451 & Tireostáticos & sintensivo & Portugal & Aquicultura (F Músculo e Pel & IProdução pr & i LGC & (em branco) \\
\hline 52198 & 3 DAV Castelc & $01-12-20$ & 520020086 & 000011459 & Inibidores $\mathrm{m}$ & Intensivo & Portugal & Aquicultura (F Músculo e Pel & I Produção pri & i LGC & (em branco) \\
\hline 52197 & DAV Castelc & $30-11-20$ & 520020084 & 000011457 & Inibidores $\mathrm{m}$ & n Intensivo ao & Portugal & Aquicultura (' Músculo e Pel & I Produção pri & i LGC & (em branco) \\
\hline 52196 & 5 DAV Castelc & $30-11-20$ & $5=530030082$ & 000011440 & Avermectina & a Intensivo ao & Portugal & Aquicultura (F Músculo e Pel & I Produção pri & i LGC & (em branco) \\
\hline 52187 & DAV Alente] & $17-12-2$ & PNCR541140056 & 00022195 & Anti-inflama & a Extensivo & Portugal & Ovinos (PNCRMúsculo & Produção & INIAV & (em branco) \\
\hline 52186 & DAV Alentej & $17-12-2$ & PNCR541140055 & 00022176 & Inibidores $\mathrm{m}$ & Intensivo & Portugal & Ovinos (PNCR Músculo & Produção & INIAV & (em branco) \\
\hline 52185 & DAV Alentej & $17-12-2$ & PNCR541140054 & 00022169 & Inibidores $\mathrm{m}$ & Extensivo & Portugal & Ovinos (PNCRMúsculo & Produção & INIAV & (em branco) \\
\hline
\end{tabular}

Figure 3 - Column "CodigoAmostra" - Example of codes to be corrected (partial view)

\section{INIAV - Extraction of NAUTILUS data}

Data from LIMS NAUTILUS database was extracted in Excel format (figure 4). From this file the following fields must be extracted in order to ensure the information necessary to meet EFSA requirements. The extractor should be asked to extract all the information without any filter so that there is no loss of information.

The present document has been produced and adopted by the bodies identified above as author(s). This task has been carried out exclusively by the author(s) in the context of a contract between the European Food Safety Authority and the author(s), awarded following a tender procedure. The present document is published complying with the transparency principle to which the Authority is subject. It may not be considered as an output adopted by the Authority. The European Food Safety Authority reserves its rights, view and position as regards the issues addressed and the conclusions reached in the present document, without prejudice to the rights of the author(s). 
- name

- name

- external_reference

- name

- u_test_reason

- u_product_description

- u_method_name

- description

- u_metodo
- formatted result

- original_unit

- sampled_on

- u_delivered_on

- authorised_on

- u_tests_required

- u_special_cases

- authorised_on

Data extraction should be done as closely as possible to the date of transmission in order to ensure that all data available for the report are properly entered into the system (NAUTILUS).

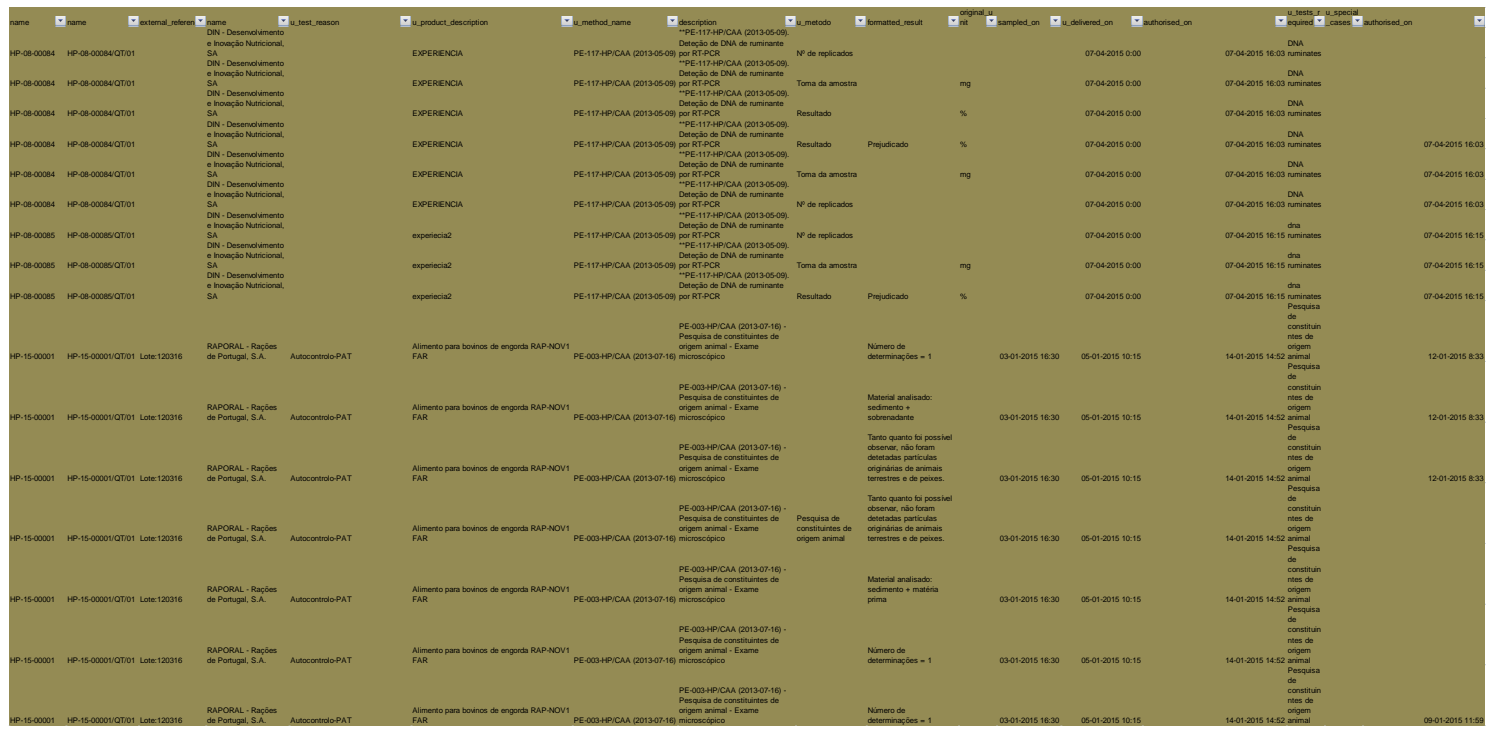

Figure 4 - Data received from NAUTILUS (partial view)

Since there is a large amount of information needed for the report that cannot be extracted from NAUTILUS, an additional Excel file with supplementary information should be requested from INIAV (figure 5). The following fields should be included in this file to ensure the information necessary to meet EFSA requirements. 
- Métodos

- Parâmetro

- Matriz

- Substâncias

- LOD e/ou CCalfa

- LOQ e/ou CCbeta
- Expressão resultados (unidades)

- Recuperação \%

- Resultado corrigido para a recuperação (Sim/Não)

- Incerteza \%

- Ensaio acreditado (Sim/Não)

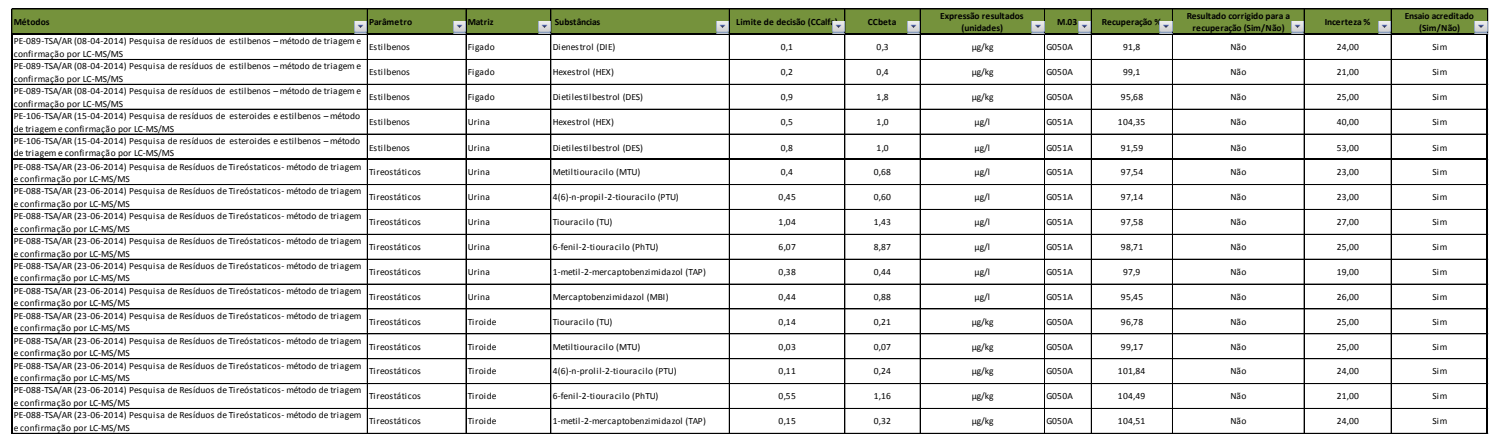

Figure 5 - Additional information received from INIAV (partial view)

\section{6) Procedure\#1}

INIAV - Residues of veterinary medicinal products

In the file with the data sent by INIAV select the "u_test_reason" column to filter / select all rows that are not related to the official control and delete them. Lines relating to own check (PAT), proficiency tests, experience and Border Inspection were deleted (Figure 2). There are names of private companies which concern samples analyzed under official control and therefore should not be deleted. In case of doubt, the information should always be confirmed with the source of the data.

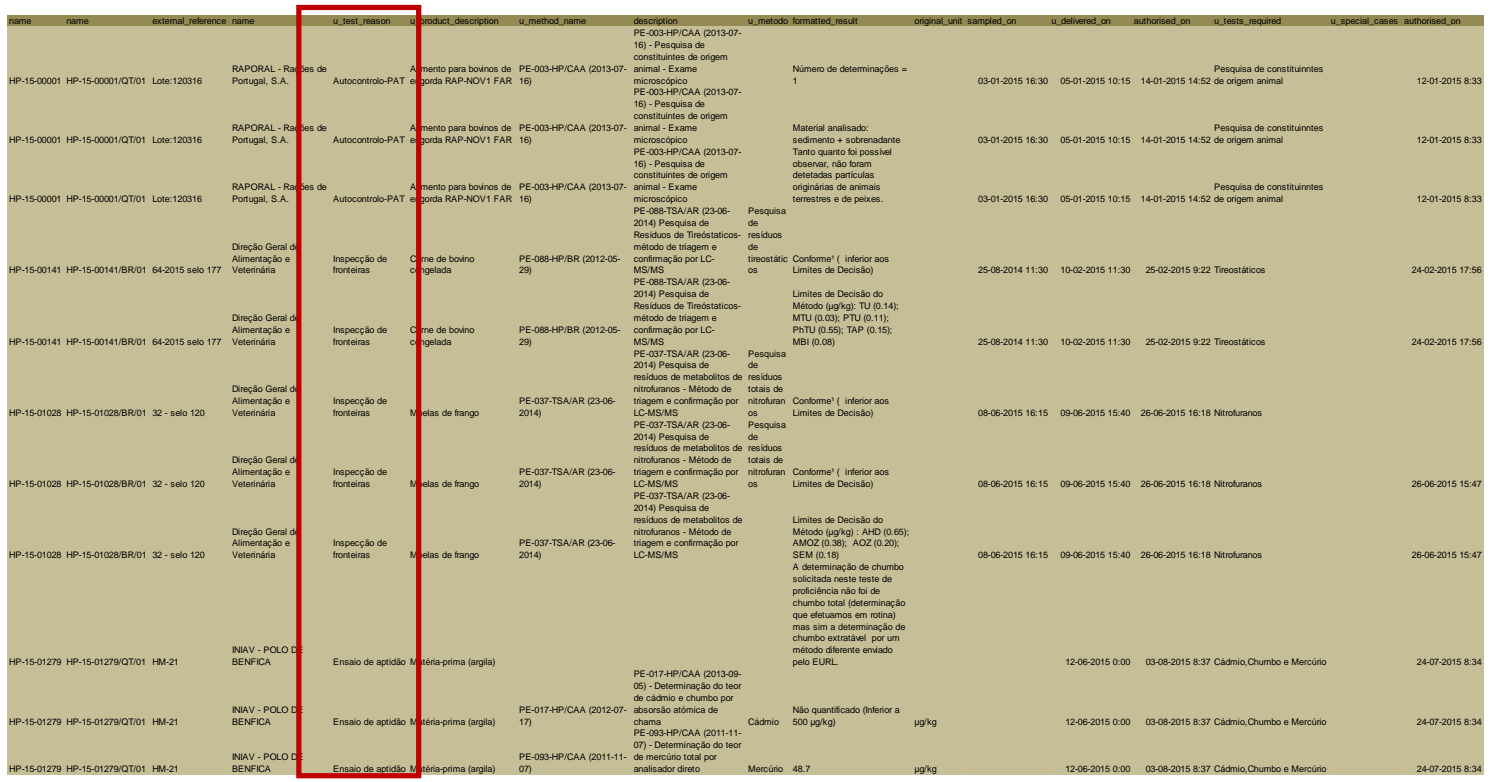

Figure 6 - File with example of rows to delete

The present document has been produced and adopted by the bodies identified above as author(s). This task has been carried out exclusively by the author(s) in the context of a contract between the European Food Safety Authority and the author(s), awarded following a tender procedure. The present document is published complying with the transparency principle to which the Authority is subject. It may not be considered as an output adopted by the Authority. The European Food Safety Authority reserves its rights, view and position as regards the issues addressed and the conclusions reached in the present document, without prejudice to the rights of the author(s). 


\section{Procedure\#2}

INIAV - Residues of veterinary medicinal products

In the column "u_metodo" filter / select all the assays that do not refer to VMPR and eliminate them, leaving only the lines corresponding to the analyses performed under VMPR (Figure 2).

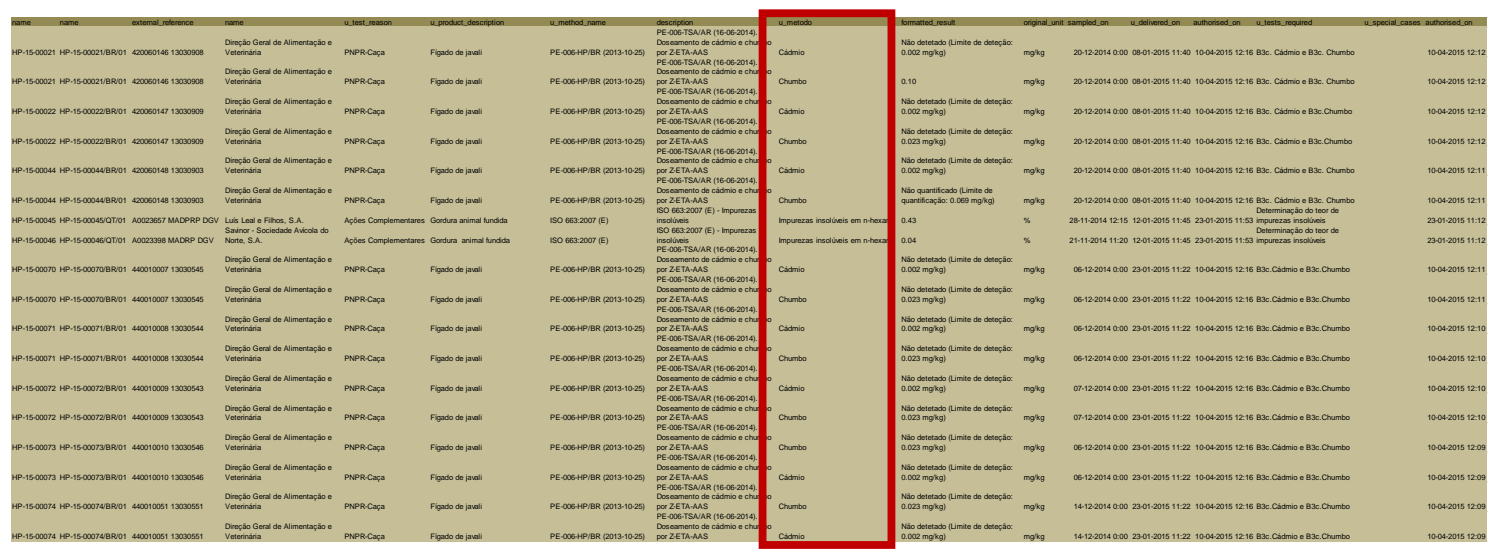

Figure 7 - File with example of rows to delete

\section{2) Procedure\#3}

INIAV - Residues of veterinary medicinal products

In the column "external_reference" separates the existing data into two columns in order to separate the external reference from the " $n$ o de selo". The new column will be referred to as "Referencia" and its content will be the only external references that will permit in the future to connect the harvest file (SIPACE) with the results (NAUTILUS) (Figure 2). Separation of the data into columns should be done with the Excel tool "text for columns" in the "Data" menu (Figure 9). Before performing this operation it is necessary to "clean" special characters or letters that may exist and format the entire column to number format. After the separation is made, it is necessary to verify that the data is correctly separated, making a filter in the new "Reference" column, if there is any "anomalous" code, it must be corrected manually.

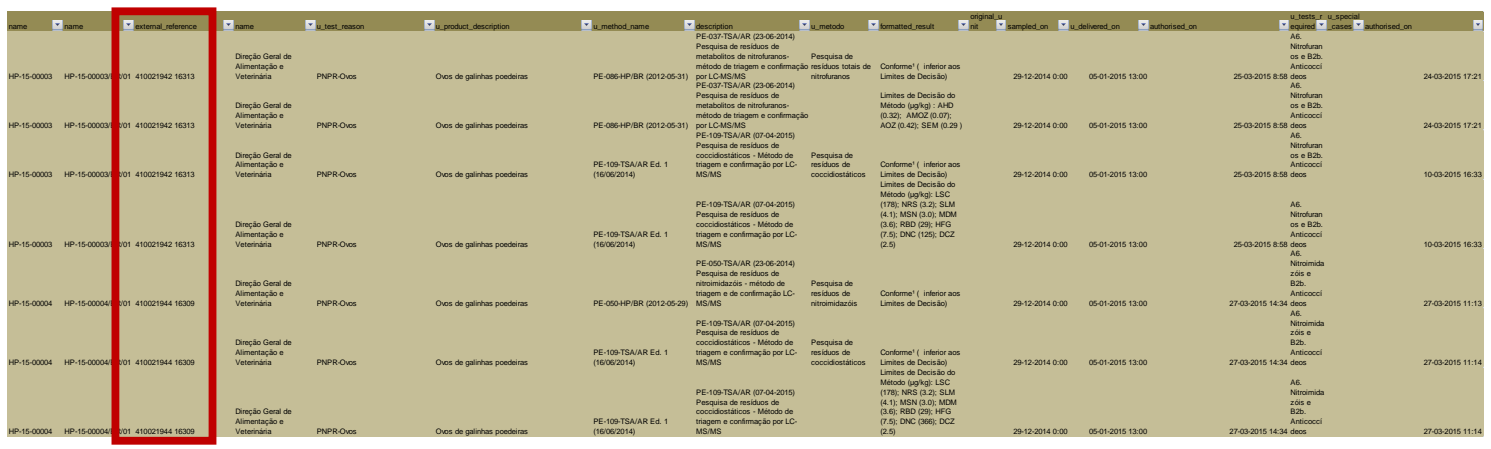

Figure 8 - File with indication of the column to be separated (partial view) 


\begin{tabular}{|l|l|}
\hline external_reference & \\
\hline 41002194216313 & \\
\hline 41002194216313 & \\
\hline 41002194216313 & \\
\hline 41002194216313 & \\
\hline 41002194416309 & \\
\hline 41002194416309 & \\
\hline 41002194416309 & \\
\hline 41002194416309 & \\
\hline 41002194416309 & \\
\hline 41002194416309 & \\
\hline 41002194716328 & \\
\hline
\end{tabular}

\begin{tabular}{|c|c|c|}
\hline Referencia & $\nabla$ & selo ${ }^{\top}$ \\
\hline 410021942 & & 16313 \\
\hline 410021942 & & 16313 \\
\hline 410021942 & & 16313 \\
\hline 410021942 & & 16313 \\
\hline 410021944 & & 16309 \\
\hline 410021944 & & 16309 \\
\hline 410021944 & & 16309 \\
\hline 410021944 & & 16309 \\
\hline 410021944 & & 16309 \\
\hline 410021944 & & 16309 \\
\hline 410021947 & & 16328 \\
\hline
\end{tabular}

Figure 9 - Detail concerning the separation of the column "external_reference". Original column on the left and separate column on the right "Referencia" (partial view)

Procedure\#4

INIAV - Residues of veterinary medicinal products

Check if there are any data collected in years before or after the reporting year. If exists they should be eliminated. Only data collected in the calendar year prior to reporting should be reported. In cases where the sample is analyzed only in the year following of the harvest, it should also be reported.

\section{DGAV/INIAV - Data processing}

of Procedure\#5

DGAV/INIAV - Residues of veterinary medicinal products

After the two files pre-treated, the lines that do not interest eliminated, we proceeded to join the two files. The files can be joined manually using the Excel tool "PROCV" from the "formulas" menu or preferably using the tool that will be available on the "PT.ON.DATA 2" platform.

The combination of the two Excel files should be done from the "CodigoAmostra" column in the collecting file (SIPACE) and the "Referencia" column in the results file (NAUTILUS) (Figure 2).

\begin{tabular}{|c|c|c|c|}
\hline name & Referencia & selo & $\begin{array}{l}\text { extern } \\
\text { al_ref name2 } \\
\text { erenc }\end{array}$ \\
\hline HP-15-014 HP-15- & 14531062032 & 19658 & 5310621 Direção Gı \\
\hline HP-15-014 HP-15- & 14531062033 & 19664 & 5310621 Direção Gı \\
\hline HP-15-014 HP-15-C & 14531062033 & 19664 & 5310621 Direção Gı \\
\hline HP-15-014 HP-15- & 14531062033 & 19664 & 5310621 Direção Gı \\
\hline HP-15-014 HP-15- & $14^{\prime} 531062033$ & 19664 & 5310621 Direção Gı \\
\hline HP-15-014 HP-15- & 14531062035 & 19675 & 531062। Direção Gı \\
\hline HP-15-014 HP-15- & 14531062035 & 19675 & 5310621 Direção Gı \\
\hline HP-15-014 HP-15- & 14531062036 & 19690 & 5310621 Direção Gı \\
\hline HP-15-014 HP-15- & 14531062036 & 19690 & 531062। Direção Gı \\
\hline HP-15-014 HP-15- & 14531062037 & 19689 & 531062। Direção Gı \\
\hline HP-15-014 HP-15- & 14531062037 & 19689 & 5310621 Direção Gı \\
\hline HP-15-014 HP-15- & 14531062038 & 19681 & 5310621 Direção Gı \\
\hline HP-15-014 HP-15- & 14531062038 & 19681 & 5310621 Direção Gı \\
\hline
\end{tabular}

\begin{tabular}{|c|c|c|c|c|c|}
\hline DAV & $\begin{array}{c}\text { ID } \\
\text { SIPACE }\end{array}$ & $\mathrm{Da}$ & $\begin{array}{l}\text { Colh CodigoA } \\
\text { ta mostra }\end{array}$ & $\begin{array}{l}\text { meros } \\
\text { Amos } \\
\text { tra }\end{array}$ & $\begin{array}{c}\text { Parametr } \\
\text { o }\end{array}$ \\
\hline \multicolumn{2}{|c|}{ DAV Setúl' 40219} & & $06-115$ & 558 & Beta- \\
\hline \multicolumn{2}{|c|}{ DAV Setúk 40220} & & $06-1153$ & & Nitrofurar \\
\hline \multicolumn{2}{|c|}{ DAV Setút 40220} & & $06-1153$ & $\mathrm{PO} 4$ & Nitrofurar \\
\hline \multicolumn{2}{|c|}{ DAV Setúĺ 40220} & 20 & & 4 & Nitrofurar \\
\hline \multicolumn{2}{|c|}{ DAV Setút'40220 } & & & & furar \\
\hline \multicolumn{2}{|c|}{ DAV Setúl 40223} & & 06 & 575 & Anticoccíd \\
\hline \multicolumn{2}{|c|}{ DAV Setúl 40223} & 20 & $06-115$ & 575 & Anticoccíd \\
\hline \multicolumn{2}{|c|}{ DAV Setúl" 40236} & 20 & $06-1153$ & 590 & Anti-inflar \\
\hline \multicolumn{2}{|c|}{ DAV Setúl 40236} & 20 & & 590 & Anti-inflar \\
\hline \multicolumn{2}{|c|}{ DAV Setúl 40238} & 20 & 3719 & 58 & Corticoste \\
\hline \multicolumn{2}{|c|}{ DAV Setúl 40238} & $2 \mathrm{v}$ & & 589 & Corticoste \\
\hline \multicolumn{2}{|c|}{ DAV Setúl 40239} & 20 & & 581 & Beta-agon \\
\hline \multicolumn{2}{|c|}{ DAV Setúl 40239} & 201 & $06-1153106203819$ & 581 & Beta-ago \\
\hline
\end{tabular}

Figure 10 - Detail of the columns for which the two files are connected. On the left the results file and on the right the collecting file (partial view) 
a) Procedure\#6

DGAV/INIAV - Residues of veterinary medicinal products

After the two files joined, it is necessary to check the rows that have not been matched. This situation can have several causes, it is necessary to analyze the faults manually trying to understand the reason for not having correspondence. This check should be done through the bulletin number in the "NumBoletimLaboratorio" column (SIPACE) and the "name" column (NAUTILUS). In case of any doubts regarding any situation, DGAV should be consulted. If there is no correspondence between lines in this case the lines should be eliminated.

! Important: Note any divergences / samples with missing information from both SIPACE and NAUTILUS. All errors detected should be reported to the involved entities so that they can correct the data in their systems.

2) Procedure\#7

DGAV/INIAV - Residues of veterinary medicinal products

Verify in all columns if there are blank cells, sometimes it is possible to get information from other columns to complete the blank cells, when it is not possible to fill in the blanks with the available information it is necessary to request the Competent Authorities (CA) to missing information. When at all it is not possible to obtain the necessary information and only if the field in question is mandatory the line is deleted.

\section{br Procedure\#8}

DGAV/INIAV - Residues of veterinary medicinal products

The information extracted from Nautilus is aggregated for some matrix and disaggregated for others, the procedure for data processing is not uniform. For matrices with aggregated results, the results are implied, that is, in the absence of results, it is understood that this is negative. In positive cases, we have to extract this information from the system, but not in a linear way since the data is mixed with other information in the "formatted_result" column. For the positive, it is still necessary to cross-check the information between the two files (collecting + results) in order to facilitate the introduction of results, it should be noted that positive results may not be all introduced in SIPACE, hence the need for Information.

As the objective is to obtain disaggregated data, it is necessary to introduce lines in a number equal to the number of analytical determinations that are defined for each sample / matrix (INIAV complementary information). In cases where the result is positive the result is manually placed using the information provided, in the other cases (negative) are filled automatically with the data provided by INIAV in the supplementary information file. In cases where there is no information it is necessary to request information from the source of the data.

(o) Procedure\#9

DGAV/INIAV - Residues of veterinary medicinal products

All results resulting from "Sequestro" and "Controlo reforçado" should be reported as "suspected sample" all the others should be reported with "objective sample". 


\section{DGAV/INIAV - Experienced difficulties}

of Note\#1

DGAV - Things to improve

Several data entry errors were detected during the data processing process, several differences between SIPACE and NAUTILUS data emerged, namely:

- matrix identification;

- Identification of the phase of the chain where the sample was collected (divergent criterion);

- Errors in the introduction of the "Sample Code" - the introduction method is also not uniform: sometimes they appear with PNPR, PNCR PMPR or DGAV; with extra spaces or numbers or wrong numbers which made data treatment very difficult. These gaps make it difficult to cross data with the INIAV file (column for which the two files are connected);

- Samples where the collection date is after the date of analysis

Not all existing results in INIAV file were launched in SIPACE. The SIPACE has been updated almost until the deadline for transmission (introduction of INIAV results), which difficult to handle the data in advance, due to delays in the analysis. The existence of several blank fields must also be improved.

Note\#2

INIAV - Things to improve

Several constraints were detected in relation to data reported by INIAV, namely:

- Data source - Data extraction must be done at the "root" of NAUTILUS, avoiding any type of filter extraction, so that all the data related to the control plans available in the system are extracted.

- Lack of harmonization of the language used - An issue that needs to be improved in order to improve data quality and reduce the need for manual intervention in data processing is the systematic use of controlled vocabulary. There are many divergences between the vocabularies used, for example the same parameter is written differently depending on the matrix where the search is done. There are also divergences between the language used in NAUTILUS and the language used in the supplementary information file sent by INIAV, this situation means that when the two files are confronted there are incompatibilities between the terms and the system cannot recognize them, requiring more manual intervention.

- $\quad$ Aggregate data - In the case of VMPR, the results are aggregated for a matrix and unbundled for others, which make it difficult to process the data, this situation means that there is no well defined column with the results; these are in the "formatted_result" column mixed with Decision limits among other information (figure 11). As previously mentioned the fact that there is no defined criterion in the introduction of the results in the system makes it difficult to enter the rows corresponding to the number of tests per matrix / group of analytes, since some matrices already have the number of lines corresponding to the analytes and others do not, sometimes this information can be duplicated, which leads to repeated lines of samples. The existence of several blank fields must be also improved.

In the supplementary information file it was necessary to standardize the languages used in order to be the same as the data file. 


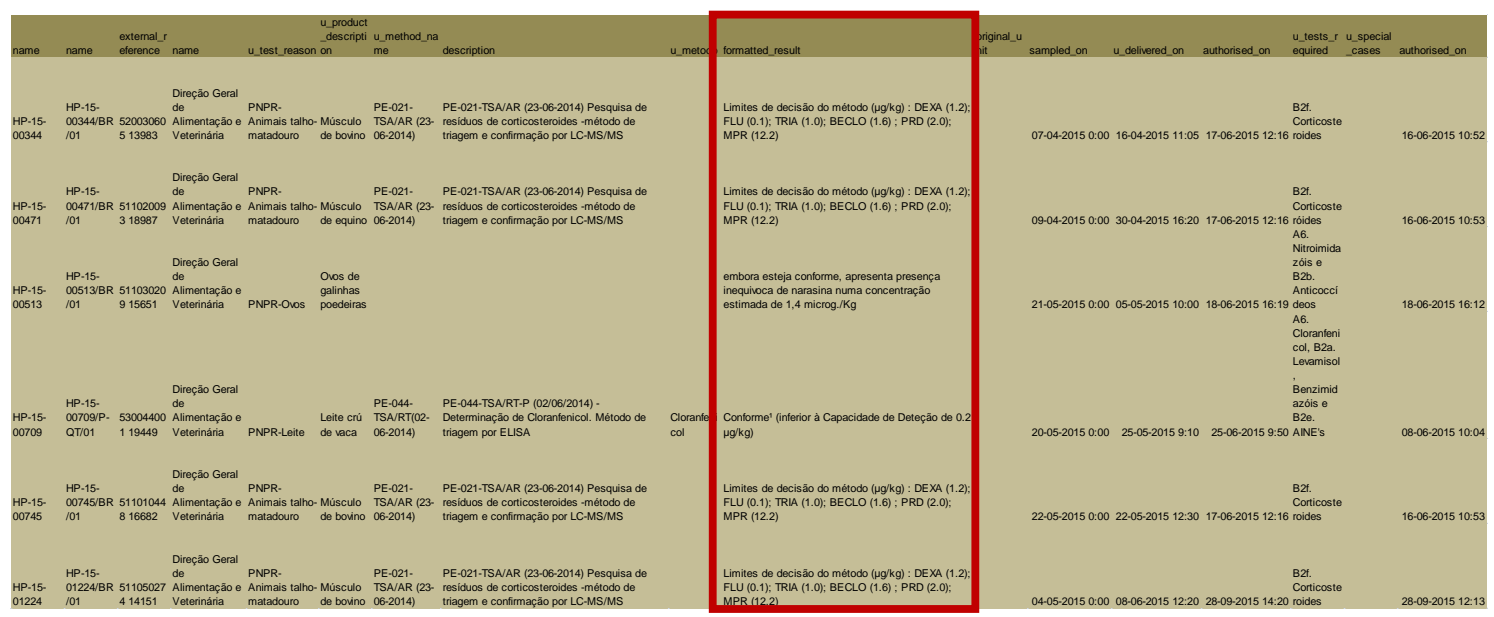

Figure 11 - Detail relative to the result column "formatted_result" (partial view)

\section{b) Note\#3}

INSA - Controlled vocabulary

The controlled vocabulary of the CA's mapped to the D1 document were all reviewed and corrected when necessary.

\section{Note\#4}

EFSA - Controlled vocabulary

EFSA has provided a document in PDF format with VMPR data reporting criteria, and an Excel file with catalogs with controlled vocabulary, this file contains a page with the catalogs of the matrices previously encoded by FoodEx2. The matrices analyzed in Portugal were all mapped with this catalog however after analysis of the DCF error report it was found that most of the FoodEx codes in this catalog are incorrect, since they do not exist in FoodEx2 Browser, so all matrices were again Coded by FoodEx2 with the Browser (see catalog FoodEx2_may2016). 